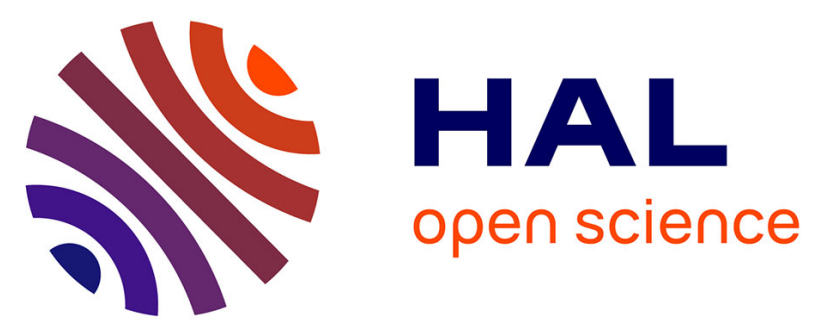

\title{
Topical Intestinal Aminoimidazole Agonists of G-Protein-Coupled Bile Acid Receptor 1 Promote Glucagon Like Peptide-1 Secretion and Improve Glucose Tolerance
}

\author{
Manuel Lasalle, Vanessa Hoguet, Nathalie Hennuyer, Florence Leroux, \\ Catherine Piveteau, Loic Belloy, Sophie Lestavel, Emmanuelle Vallez, Emilie \\ Dorchies, Isabelle Duplan, et al.
}

\section{- To cite this version:}

Manuel Lasalle, Vanessa Hoguet, Nathalie Hennuyer, Florence Leroux, Catherine Piveteau, et al.. Topical Intestinal Aminoimidazole Agonists of G-Protein-Coupled Bile Acid Receptor 1 Promote Glucagon Like Peptide-1 Secretion and Improve Glucose Tolerance. Journal of Medicinal Chemistry, 2017, 60 (10), pp.4185-4211. 10.1021/acs.jmedchem.6b01873 . inserm-02115415

\section{HAL Id: inserm-02115415 https://www.hal.inserm.fr/inserm-02115415}

Submitted on 30 Apr 2019

HAL is a multi-disciplinary open access archive for the deposit and dissemination of scientific research documents, whether they are published or not. The documents may come from teaching and research institutions in France or abroad, or from public or private research centers.
L'archive ouverte pluridisciplinaire HAL, est destinée au dépôt et à la diffusion de documents scientifiques de niveau recherche, publiés ou non, émanant des établissements d'enseignement et de recherche français ou étrangers, des laboratoires publics ou privés. 


\title{
Topical intestinal aminoimidazole agonists of G-
}

\author{
Protein-Coupled Bile Acid Receptor 1 promote
}

\section{Glucagon Like Peptide-1 secretion and improve}

\section{glucose tolerance.}

Manuel Lasalle ${ }^{\dagger \#}$, Vanessa Hoguet ${ }^{\dagger \#}$, Nathalie Hennuyer ${ }^{\ddagger}$, Florence Leroux ${ }^{\dagger}$, Catherine Piveteau $^{\dagger}$, Loïc Belloy ${ }^{\ddagger}$, Sophie Lestavel ${ }^{\ddagger}$, Emmanuelle Vallez ${ }^{\ddagger}$, Emilie Dorchies ${ }^{\ddagger}$, Isabelle Duplan ${ }^{\ddagger}$, Emmanuel Sevin ${ }^{\S}$, Maxime Culot $^{\S}$, Fabien Gosselet ${ }^{\S}$, Rajaa Boulahjar ${ }^{\dagger}$, Adrien Herledan $^{\dagger}$, Bart Staels ${ }^{\ddagger}$, Benoit Deprez $^{* \dagger}$, Anne Tailleux ${ }^{\ddagger}$ Julie Charton* ${ }^{\star \diamond}$

${ }^{\dagger}$ Univ. Lille, Inserm, Institut Pasteur de Lille, U1177 - Drugs and Molecules for living Systems, F-59000 Lille, France.

${ }^{\ddagger}$ Univ. Lille - EGID, Inserm, CHU Lille, Institut Pasteur de Lille, U1011 - Nuclear receptors, cardiovascular diseases and diabetes, F-59000 Lille, France.

${ }^{\S}$ Univ. Artois, EA 2465 - Blood-brain barrier laboratory (LBHE), F-62300 Lens, France.

\# These authors contributed equally to this work.

${ }^{\diamond}$ These authors contributed equally to this work.

KEYWORDS. TGR5, Aminothioimidazole, GLP-1, glucose tolerance 
ABSTRACT. G-Protein-Coupled Bile Acid Receptor 1 (GP-BAR1), also known as Takeda Gprotein-coupled receptor 5 (TGR5) is a G Protein Coupled Receptor sensitive to bile acids. Its role in various organs, tissues and cell types, specifically in intestinal endocrine L cells and brown adipose tissue, has made it a promising therapeutical target in several diseases, especially type 2 diabetes and metabolic syndrome. However, recent studies have also shown deleterious on-target effects of systemic TGR5 agonists. To avoid these systemic effects while stimulating the incretin Glucagon Like Peptide-1 (GLP-1) secreting enteroendocrine L-cells, we have designed and obtained a series of potent TGR5 agonists with low intestinal permeability. Some of our weakly permeable compounds display potent GLP-1 secretagogue effect and low effect on gallbladder volume, which translates into improved glucose homeostasis in a preclinical murine model of diet-induced obesity and insulin-resistance. Herein we describe the design, synthesis, characterization, and biological evaluation of such compounds, making the proof of concept of the potential of topical intestinal TGR5 agonists as therapeutic agents in type 2 diabetes using compound 24.

\section{INTRODUCTION.}

Bile acids have been known for over a decade to act not only as lipid solubilizing agents during digestion, but also as signaling molecules, through two main receptors ${ }^{1}$ : the nuclear receptor FXR $^{2}$ (identified in 1999), and the G-Protein-Coupled Bile Acid Receptor TGR5 $5^{3,4}$ (aka GPBAR1, GPR131, M-BAR identified in 2002). TGR5 acts as a sensor of the prandial state of the organism, by detecting bile acids in various tissues, organs, and cells, such as enteroendocrine Lcells, brown adipose tissue, skeletal striated muscles, but also gallbladder, immune cells and neurons. Based on the existing functional and pharmacological data in preclinical models, TGR5 
appears as an attractive target to treat metabolic diseases through different pathways ${ }^{5}$. First, TGR5 expressed in enteroendocrine L-cells promotes the transcription of the proglucagon gene expression and the secretion of the incretin Glucagon-like peptide 1 (GLP-1), which displays numerous beneficial effects on glucose and energy homeostasis (insulin secretion, beta cell preservation, appetite regulation, gastric emptying $)^{6}$. Second, TGR5 activation in brown adipose tissue (BAT) and muscle increases deiodinase 2 gene expression and consequently conversion of the inactive T4 hormone into active thyroxin T3, and uncoupling protein-1 (UCP-1) activation leading to energy expenditure. Interestingly, the link between TGR5 activation in BAT and energy expenditure firstly demonstrated in mouse ${ }^{7}$ has been recently shown also in humans ${ }^{8}$. Nevertheless, recent investigations in preclinical animal models have suggested that systemic TGR5 agonists may trigger unwanted effects such as gallbladder swelling ${ }^{9,10}$, itching ${ }^{11}$, or more recently cardiovascular issues ${ }^{12-14}$. In this context, TGR5 localization on enteroendocrine L-cells in the intestine epithelium offers a new opportunity. Indeed, the development of intestinaltargeted agonists may lead to GLP-1 secretagogue compounds with a systemic bioavailability low enough to get rid of on-target as well as off-target systemic side effects.

We aim to obtain compounds with low gastro-intestinal (GI) absorption that can exert their biological activity locally in GI tract while minimizing systemic exposure. ${ }^{15}$ This strategy seemed particularly suitable for the development of TGR5 agonists because it would enable TGR5 agonists to stimulate the GLP-1 release by enteroendocrine L-cells without triggering any other TGR5-related effect ${ }^{16,17}$. To access such compounds, we decided to design our compounds as chimeric molecules associating a "pharmacophore" that would bear the pharmacological activity, and a "kinetophore", that would control the kinetic properties of the whole molecule, without modifying significantly its effect on the receptor. The kinetophore concept was 
introduced in 2006 to describe a highly polar and/or large and hindered chemical moiety that is tethered to a pharmacologically active structure, to drastically modify its pharmacokinetic properties, especially by decreasing its oral absorption ${ }^{18}$.

Our efforts firstly focused on optimizing the pharmacophore part and developing structureactivity relationships to determine where to link the kinetophore on the molecules. Analysis of an in-house HTS hit family showed a similarity to a TGR5 agonist (CpdA) we had synthesized to use as a reference, described in a patent by Exelixis ${ }^{19}$. To increase the diversity of this triazole family, a classical C-to-N isosteric replacement strategy to the CpdA led to original compound $\mathbf{1}$ (scheme 1). Surprisingly, although very structurally close to CpdA compound $\mathbf{1}$ was completely inactive on TGR5 showing SAR in our aminothiotriazole series contrasting with that of Exelixis. Substitution of the extracyclic nitrogen by a methyl gave compound $\mathbf{2}$ that showed promising activity on both human and murine TGR5 receptors. Switch of the central scaffold from a triazole to an imidazole led to compound $\mathbf{3}$ with a drastic increase of potency (from $180 \mathrm{nM}$ to $0.8 \mathrm{nM}$ on the murine receptor). Compound $\mathbf{3}$ was the starting point for the design of agonists bearing several kinetophore moieties. In this paper, we describe SAR around $\mathbf{3}$, followed by the design, synthesis and characterization of kinetophore bearing analogs in pharmacokinetic and pharmacodynamics models. 
Scheme 1. Isosteric replacement strategy and scaffold switching.
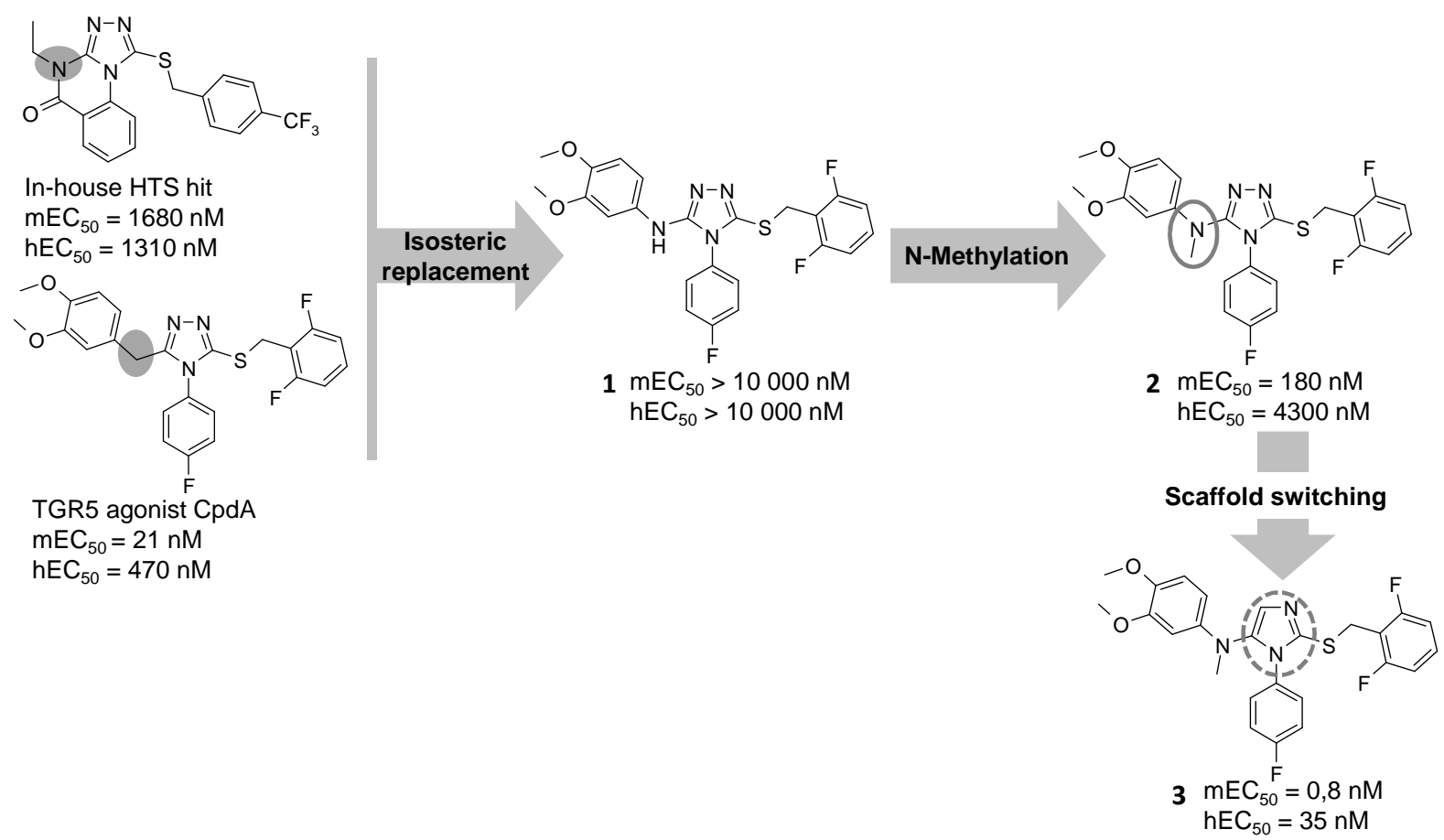

\section{CHEMISTRY}

3-amino-5-thio-[1,2,4]triazole series. Synthesis of the 3-amino-5-thio-[1,2,4]triazole derivatives was performed in four to five steps with moderate yield (scheme 2). The first step was the synthesis of the core aminothiotriazole, by a one-pot two-steps reaction ${ }^{20}$. Selective substitution of the sulfur atom was then carried out in classic nucleophilic substitution conditions to afford the 5-benzylsulfanyl-4-phenyl-4H-[1,2,4]triazol-3-ylamine derivative. Access to compound $\mathbf{1}$ was enabled via a Chan-Lam coupling, requiring protection and deprotection steps of the exocyclic nitrogen by an acetyl group. Compound $\mathbf{2}$ was obtained through the same coupling reaction after methylation of the nitrogen by reductive amination. 
Scheme 2. Synthetic route to $\mathbf{1 - 2}$.

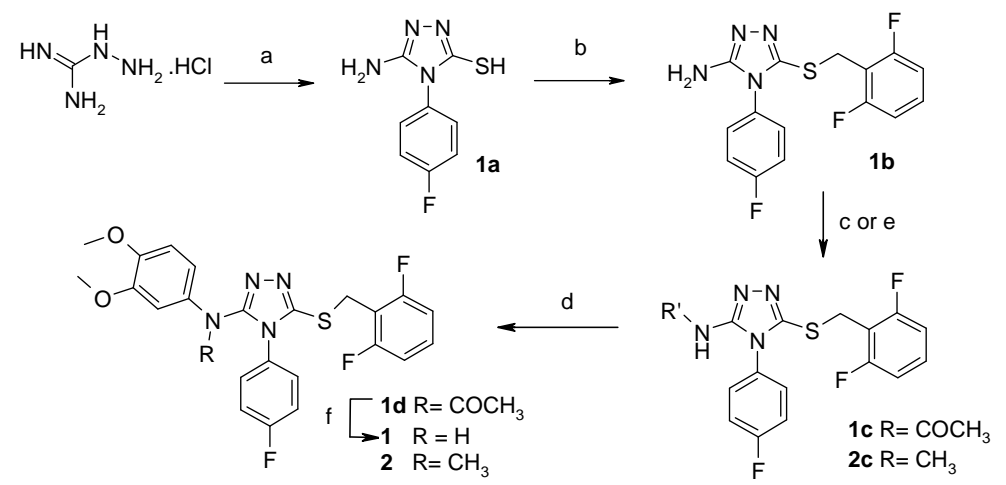

Reagents and conditions: (a) i ) 4-fluorophenylisothiocyanate, DIEA, DMF, $50^{\circ} \mathrm{C}, 15 \mathrm{~h}$ ii) $\mathrm{NaOH}$ $2 \mathrm{M}, 50^{\circ} \mathrm{C}, 60 \mathrm{~h}, 87 \%$ (b) 2-bromomethyl-1,3-difluoro-benzene, DIEA, $\mathrm{CH}_{2} \mathrm{Cl}_{2}$, room temp., 3h, $98 \%$ (c) i) $\mathrm{MeONa}$, paraformaldehyde, $\mathrm{MeOH}$, room temp., 16h ii) $\mathrm{NaBH}_{4}, \mathrm{MeOH}$, reflux, 30 min, 76\% (d) Chan-Lam coupling, 3,4-dimethoxyphenylboronic acid, pyridine, $\mathrm{Cu}(\mathrm{OAc})_{2}$, MS $4 \AA$, $\mathrm{CH}_{2} \mathrm{Cl}_{2}$, room temp., 24-48h, 11-50\% (e) $\mathrm{Ac}_{2} \mathrm{O}, \mathrm{CH}_{2} \mathrm{Cl}_{2}$, room temp., 30 min, $66 \%$ (f) $\mathrm{AcCl}$, EtOH, reflux, $30 \mathrm{~min}, 57 \%$.

5-amino-2-thio-imidazole series. 5-amino-2-thio-imidazoles derivatives were obtained through a 6 steps synthetic route, using simple building blocks such as aniline, amino-acids or benzyl derivatives to speed up the exemplification in this family. The first step was a mono-methylation of the desired aniline by reductive amination. The methylaniline or N-methylbenzylamine was firstly acetylated by chloroacetyl chloride. Then a nucleophilic substitution of the chloride by ammonia afforded the primary amine. This synthetic route was later optimized into a more convenient and efficient route: 1-propylphosphonic acid cyclic anhydride acylation with a Boc $\mathrm{N}$-protected glycine followed by an acidic deprotection of the amino group. Use of either a commercial isothiocyanate or an aniline and TCDI led to the thiourea intermediate. The sulfur atom could then be selectively alkylated by a benzyl derivative to give the corresponding isothiourea. Finally, we took advantage of the 1-propylphosphonic acid cyclic anhydride - 
mediated cyclodehydration method that we have developed previously ${ }^{21}$ to obtain the desired 5amino-2-thioimidazole compounds from the isothiourea intermediates. (Schemes 3-5)

Scheme 3. Synthetic route to 3-6

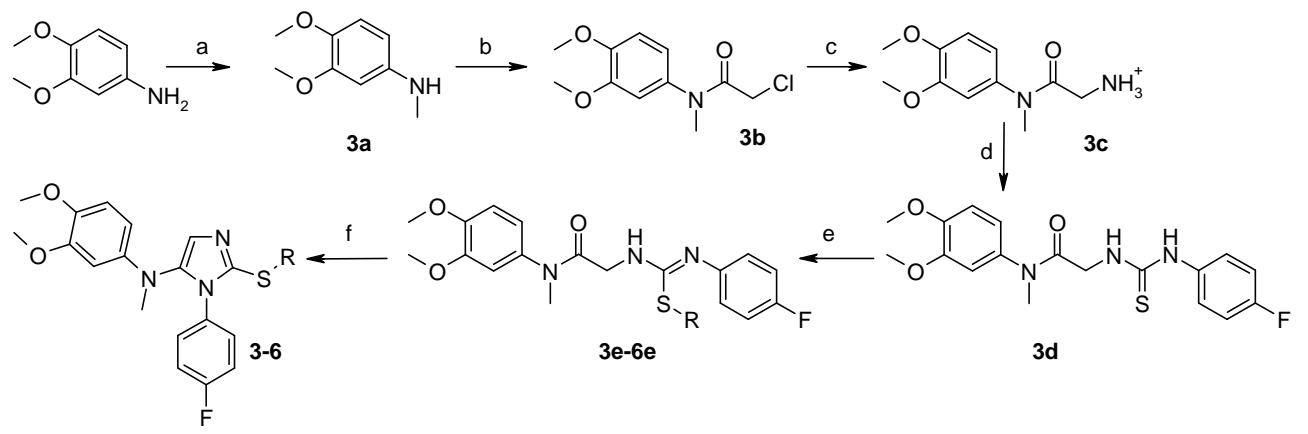

Reagents and conditions: (a) i) paraformaldehyde, $\mathrm{MeONa}$, room temp., 16h ii) $\mathrm{NaBH}_{4}, \mathrm{MeOH}$, reflux, $1-3 \mathrm{~h}, 77 \%$ (b) Chloroacetyl chloride, DIEA, $\mathrm{CH}_{2} \mathrm{Cl}_{2}, 0^{\circ} \mathrm{C}, 30 \mathrm{~min}$ (c) aq. $\mathrm{NH}_{3}, \mathrm{EtOH}$, $65^{\circ} \mathrm{C}, 1 \mathrm{~h}, 75 \%$ (over two steps) (d) 4-fluorophenylisothiocyanate, $\mathrm{NEt}_{3}, \mathrm{EtOH}$, room temp., 15 $\min , 76 \%$ (e) $\mathrm{R}-\mathrm{Cl}$, NaI, $\mathrm{K}_{2} \mathrm{CO}_{3}, \mathrm{CH}_{3} \mathrm{CN}$, room temperature, 16h, 90-98\% (f) 1propylphosphonic acid cyclic anhydride, DIEA, EtOAc, $150^{\circ} \mathrm{C}(\mu \mathrm{W}), 10-40 \mathrm{~min}$, or reflux (classical heating), 24h, 32-61\%.

Scheme 4. Synthetic route to 7-12

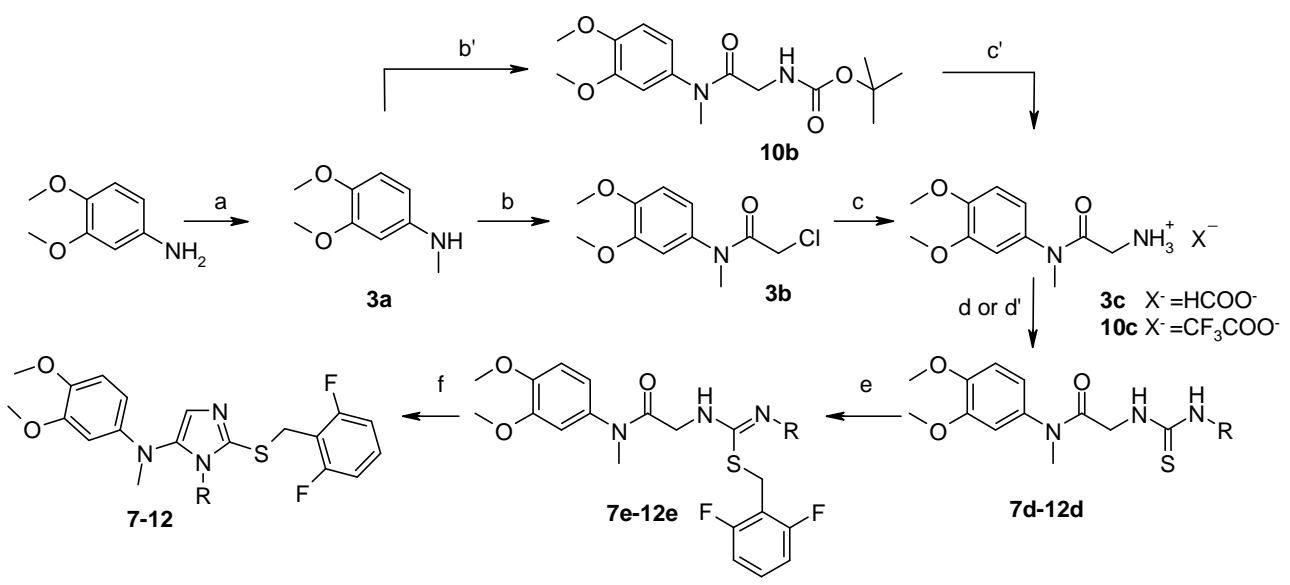


Reagents and conditions: (a) i) paraformaldehyde, MeONa, room temp., 16h ii) $\mathrm{NaBH}_{4}, \mathrm{MeOH}$, reflux, $1-3 \mathrm{~h}, 77 \%$ (b) Chloroacetyl chloride, DIEA, $\mathrm{CH}_{2} \mathrm{Cl}_{2}, 0^{\circ} \mathrm{C}, 30 \min$ (c) aq. $\mathrm{NH}_{3}, \mathrm{EtOH}$, $65^{\circ} \mathrm{C}, 1 \mathrm{~h}, 75 \%$ (over two steps) (b') Boc-Gly-OH, 1-propylphosphonic acid cyclic anhydride, DIEA, EtOAc, room temp., 30 min-48h, 100\% (c') TFA (30 \%) /DCM, room temp., 30 min, $100 \%$ (d) $\mathrm{R}-\mathrm{N}=\mathrm{C}=\mathrm{S}, \mathrm{NEt}_{3}, \mathrm{EtOH}$, room temp. or $60^{\circ} \mathrm{C}, 15 \mathrm{~min}$ to overnight, $30-53 \%$ (d') aniline, TCDI, $\mathrm{NEt}_{3}$, dioxane, room temp- $60^{\circ} \mathrm{C}$, overnight, $49 \%$ (e) 2-bromomethyl-1,3-difluorobenzene, NaI, $\mathrm{K}_{2} \mathrm{CO}_{3}, \mathrm{CH}_{3} \mathrm{CN}$, room temperature, 16h, 82-99\% (f) 1-propylphosphonic acid cyclic anhydride, DIEA, EtOAC, $150^{\circ} \mathrm{C}(\mu \mathrm{W}), 10-40 \mathrm{~min}$, or reflux (classical heating), 24h, 11$63 \%$.

Scheme 5. Synthetic route to $\mathbf{1 3 - 1 8}$

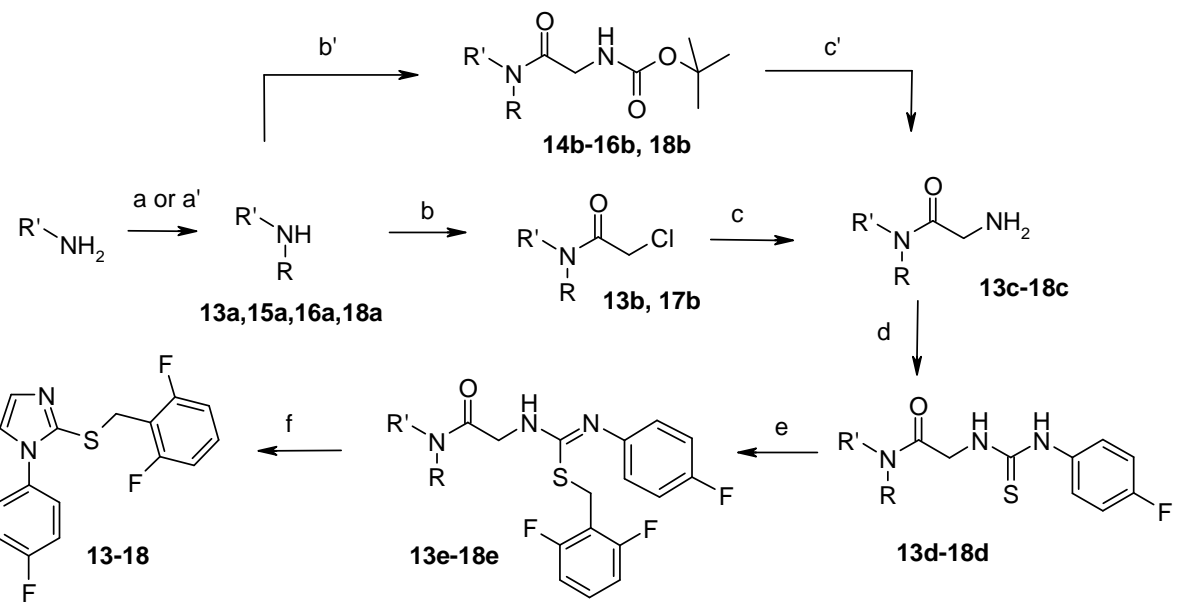

Reagents and conditions: (a) i) paraformaldehyde, $\mathrm{MeONa}$, room temp., $16 \mathrm{~h}$ ii) $\mathrm{NaBH}_{4}, \mathrm{MeOH}$, reflux, 1-3h, 51-96\% (a') Allyl bromide, $\mathrm{K}_{2} \mathrm{CO}_{3}$, DMF, $80^{\circ} \mathrm{C}$, $16 \mathrm{~h}$ (b) Chloroacetyl chloride, DIEA, $\mathrm{CH}_{2} \mathrm{Cl}_{2}, 0^{\circ} \mathrm{C}, 30$ min (c) aq. $\mathrm{NH}_{3}, \mathrm{EtOH}, 65^{\circ} \mathrm{C}, 1 \mathrm{~h}, 75 \%$ (b') Boc-Gly-OH, 1propylphosphonic acid cyclic anhydride, DIEA, EtOAc, room temp., 30 min-48h, 79-100\% (c') TFA (30\%)/ $/ \mathrm{CH}_{2} \mathrm{Cl}_{2}$, room temp., 30 min (d) 4-fluorophenylisothiocyanate, $\mathrm{NEt}_{3}, \mathrm{EtOH}$, room temp., 15-60 min, 90-100\% (e) 2-bromomethyl-1,3-difluoro-benzene, $\mathrm{NaI}, \mathrm{K}_{2} \mathrm{CO}_{3}, \mathrm{CH}_{3} \mathrm{CN}$, 
room temperature, overnight, 58-100\% (f) 1-propylphosphonic acid cyclic anhydride, DIEA, EtOAc, $150^{\circ} \mathrm{C}(\mu \mathrm{W}), 10-40 \mathrm{~min}$, or reflux (classical heating), $24 \mathrm{~h}, 10-59 \%$.

Compound 19 was prepared from 4-fluorophenylisothiocyante and 2-aminoacetonitrile. After addition on the isothiocyanate, alkylation using 2-bromomethyl-1,3-difluoro-benzene on the sulfur atom was followed by spontaneous cyclization into the 5-amino-2-thioimidazole 19b. The amino group was then acylated using 3,4-dimethoxybenzoic acyl chloride, prepared from the corresponding carboxylic acid to give compound 19. (scheme 6)

Scheme 6. Synthetic route to 19

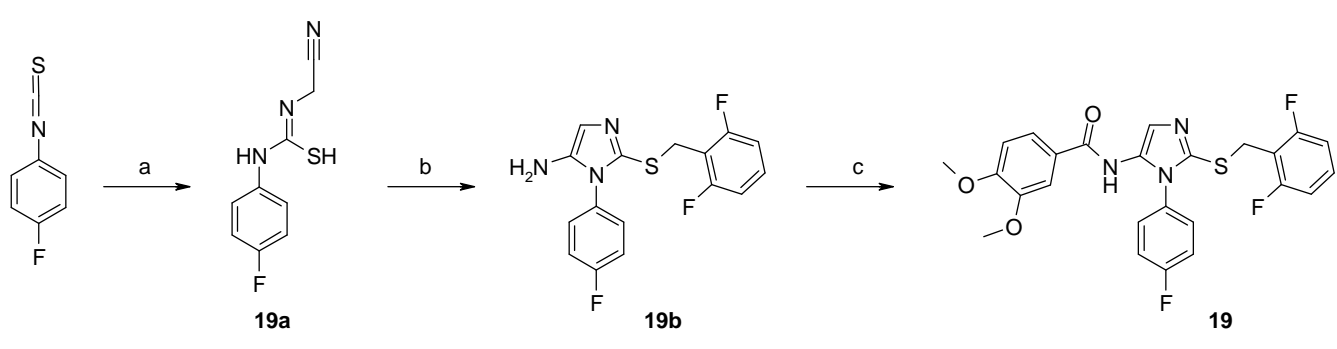

Reagents and conditions: (a) 2-aminoacetonitrile hydrochloride, $\mathrm{NEt}_{3}, \mathrm{DMF}$, room temp. to $0^{\circ} \mathrm{C}$, 30 min, $80 \%$ (b) 2-bromomethyl-1,3-difluoro-benzene, DIEA, $\mathrm{CH}_{3} \mathrm{CN}$, room temp., 5 min (c) 3,4-dimethoxybenzoic acid, thionyl chloride, $\mathrm{CH}_{2} \mathrm{Cl}_{2}$, THF, Pyridine, room temp., $4 \mathrm{~h}, 31 \%$.

To prepare compound 22, 4-bromo-2,6-difluorobenzyl alcohol was reacted with mesyl chloride in presence of trimethylamine. (NMR analysis of the product revealed that the product was not the expected mesylate, but rather the benzyl chloride). This benzyl derivative was then used to afford the corresponding imidazole 20b in two steps (scheme 7). A Sonogashira coupling using N,N-dimethylpropargylamine was then performed on this imidazole to give 20. The tertiary 
amine was finally methylated to give the corresponding quaternary ammonium, which was first obtained as an iodide (21), and then as a formate (22) after purification by preparative HPLC in alkaline buffer (ammonium formate buffer $\mathrm{pH}=9.2$ ).

Scheme 7. Synthetic route to $\mathbf{2 0 - 2 2}$

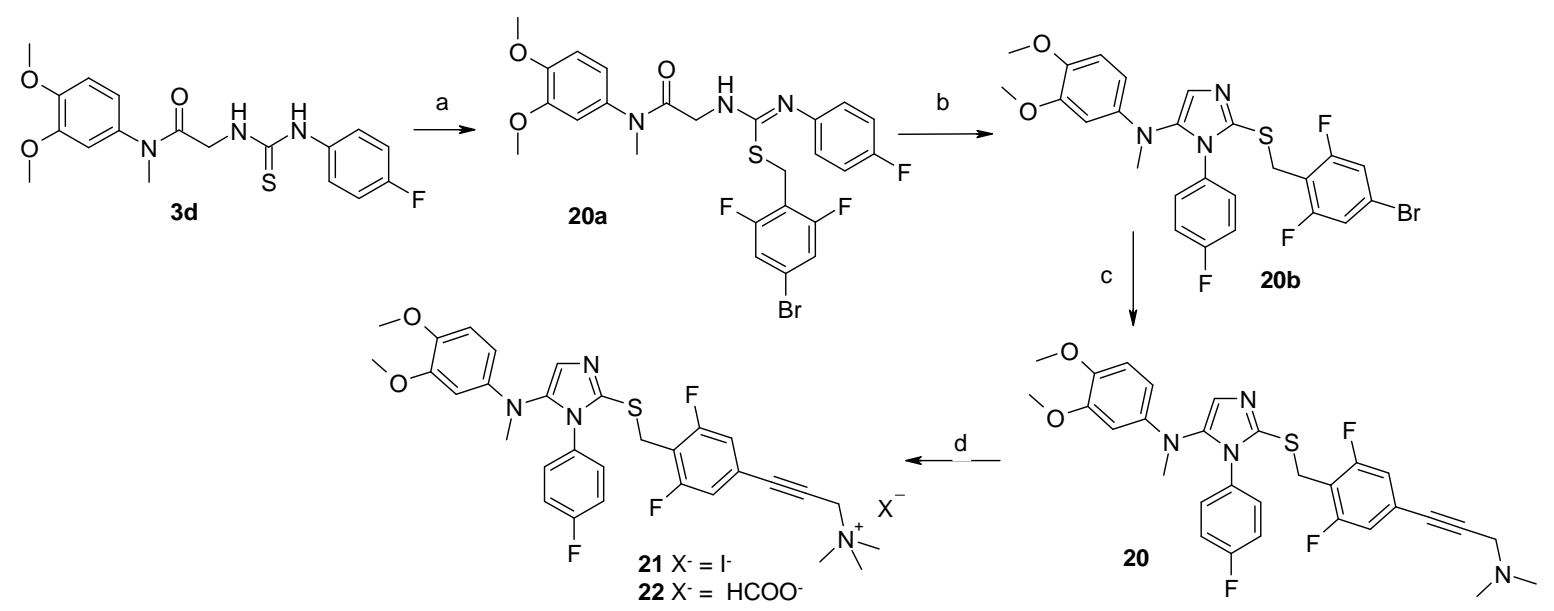

Reagents and conditions: (a) R-Cl, NaI, $\mathrm{K}_{2} \mathrm{CO}_{3}, \mathrm{CH}_{3} \mathrm{CN}, 16 \mathrm{~h}$, room temp. 95\% (b) 1propylphosphonic acid cyclic anhydride, DIEA, EtOAc, reflux, 24h, $74 \%$ (c) N,NDimethylpropargylamine, pyrrolidine, $\mathrm{CuI}, \mathrm{PdCl}_{2}(\mathrm{dppf})_{2}, \mathrm{DMF}, 80^{\circ} \mathrm{C}, 16 \mathrm{~h}, 47 \%$ (d) $\mathrm{MeI}$, THF/Et $2 \mathrm{O}$, room temp., 2-6h, 17-19\%.

The compounds bearing a quaternary ammonium $\mathbf{2 3}$ or a sulfonate $\mathbf{2 4}$ were obtained through a one-step synthesis from the chloropropyl derivative $\mathbf{2 3 b}$. Synthesis of the corresponding benzyl derivative 23ii was carried out starting with the 2,6-difluoro-4-hydroxybenzonitrile (scheme 8). Alcaline hydrolysis of the cyano group was followed by esterification with methanol in acidic conditions. The corresponding methyl ester was reduced into the benzyl alcohol using DIBAlH to give compound 23i. Selective alkylation of the phenolic hydroxyl by 1-bromo-3- 
chloropropane was then performed, followed by activation of the benzylic carbon using mesyl chloride to give the compound 23ii.

Scheme 8. Synthetic route to intermediate 23ii

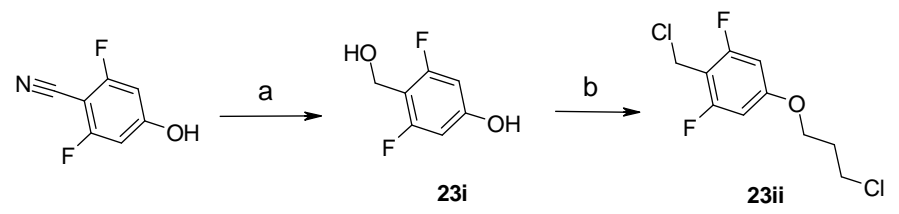

Reagents and conditions : (a) i) $\mathrm{NaOH}, \mathrm{H}_{2} \mathrm{O}$, reflux, 24h, 94\% ii) $\mathrm{H}_{2} \mathrm{SO}_{4}, \mathrm{MeOH}$, reflux, $18 \mathrm{~h}$, $90 \%$ iii) DIBAlH, THF, $0^{\circ} \mathrm{C}, 1.5 \mathrm{~h}$ then NaK-tartrate aq (1M), room temp., $0.5 \mathrm{~h}, 80 \%$ (b) i) $\mathrm{Cl}\left(\mathrm{CH}_{2}\right)_{3} \mathrm{Br}, \mathrm{K}_{2} \mathrm{CO}_{3}, \mathrm{CH}_{3} \mathrm{CN}$, reflux, 3h, $96 \%$ ii) $\mathrm{MsCl}, \mathrm{NEt}_{3}, \mathrm{CH}_{2} \mathrm{Cl}_{2}, 0^{\circ} \mathrm{C}$ to room temp., 16h, $100 \%$.

Intermediate 23ii was used to obtain the corresponding imidazole $\mathbf{2 3 b}$ in two steps (Scheme 9). The sulfonate derivative $\mathbf{2 4}$ was readily synthesized from $\mathbf{2 3 b}$ using sodium sulfite and sodium iodide in a dioxane/water mixture under microwave irradiation ${ }^{22}$. Quaternary ammonium $\mathbf{2 3}$ was obtained by reaction of $\mathbf{2 3 b}$ with 1,4-diazabicylco[2.2.2] octane (DABCO) in acetonitrile under microwave irradiation.

Scheme 9. Synthetic route to intermediate 23-24 


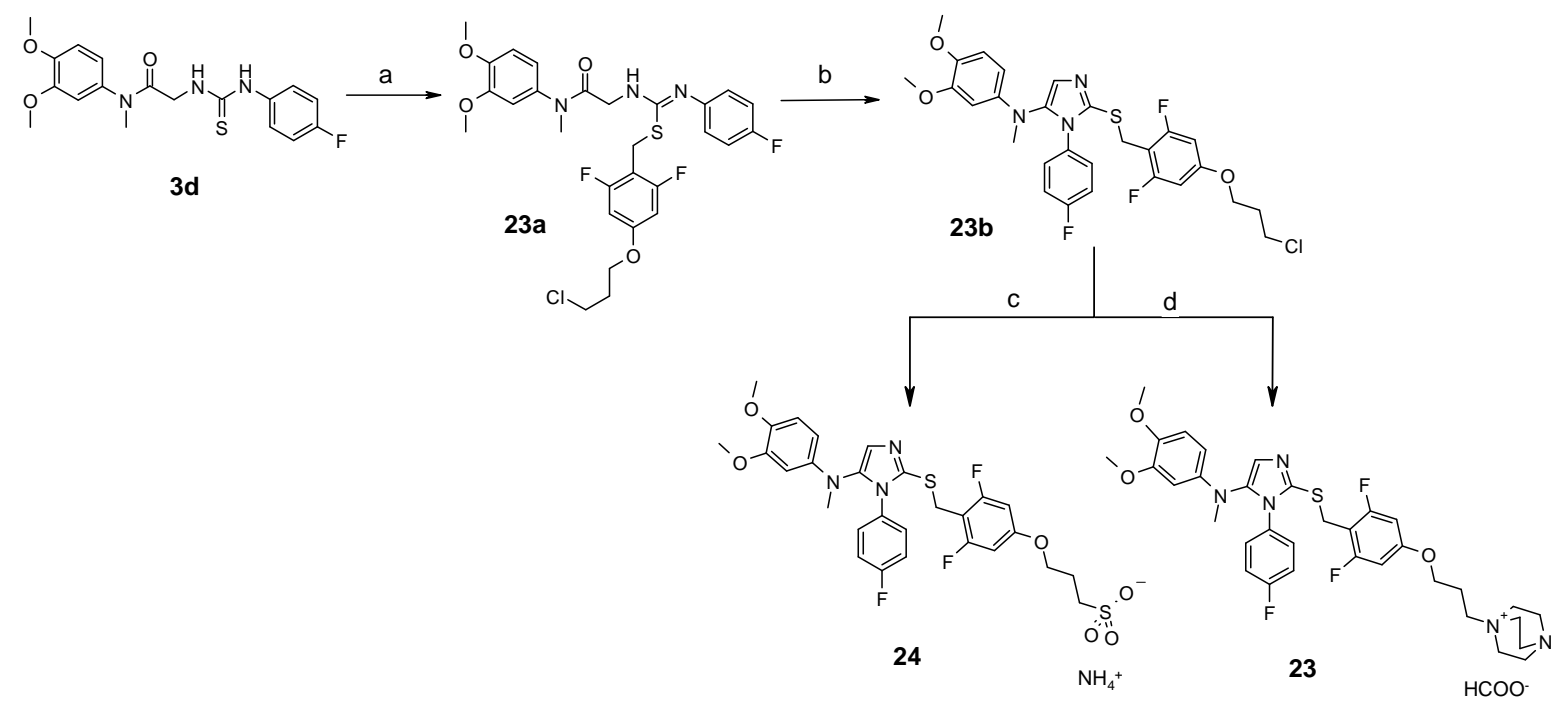

Reagents and conditions: (a) 23ii, $\mathrm{K}_{2} \mathrm{CO}_{3}, \mathrm{CH}_{3} \mathrm{CN}$, room temp., 16h, $73 \%$ (b) 1propylphosphonic acid cyclic anhydride, DIEA, EtOAc, reflux, 28h, 96\% (c) $\mathrm{NaI}, \mathrm{Na}_{2} \mathrm{SO}_{3}$, dioxane $/ \mathrm{H}_{2} \mathrm{O}(1 / 1), \mu \mathrm{W}, 130^{\circ} \mathrm{C}, 100 \mathrm{~min}, 36 \%$ (d) $\mathrm{DABCO}, \mathrm{CH}_{3} \mathrm{CN}, \mu \mathrm{W}, 100^{\circ} \mathrm{C}, 30 \mathrm{~min}, 23 \%$.

Intermediate 25iii was obtained in 3 steps starting from intermediate $\mathbf{2 3 i}$. The phenolic oxygen was first alkylated using 1,3-dibromopropane to give intermediate $\mathbf{2 5 i}$. Then a nucleophilic substitution using tert-butyl N-tert-butoxycarbonylcarbamate was carried out on the bromopropyl derivative to afford intermediate 25ii. This benzylic alcohol was then converted into the benzyl chloride derivative 25iii using mesyl chloride as describe above for intermediate 23ii. 
Scheme 10. Synthetic route to intermediate 25 iii

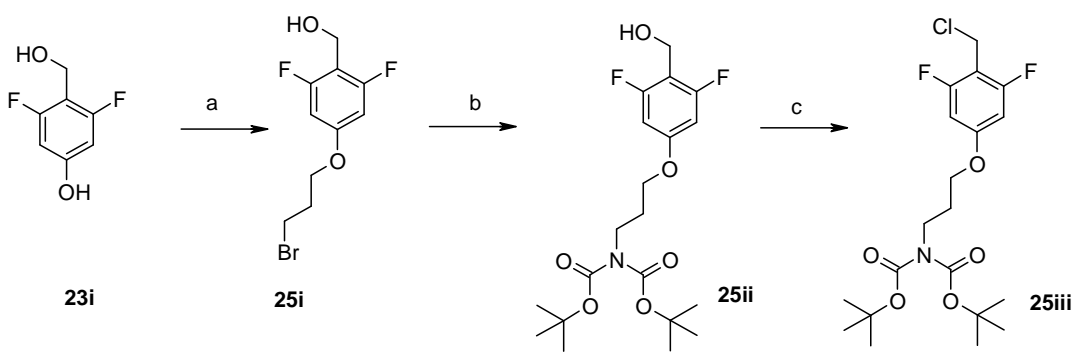

Reagents and conditions: (a) 1,3-dibromopropane, $\mathrm{K}_{2} \mathrm{CO}_{3}, \mathrm{CH}_{3} \mathrm{CN}$, reflux, 3h, 76\% (b) tert-butyl N-tert-butoxycarbonylcarbamate, $\mathrm{Cs}_{2} \mathrm{CO}_{3}, \mathrm{DMF}, 70^{\circ} \mathrm{C}, 30 \mathrm{~min}, 95 \%$ (c) $\mathrm{NEt}_{3}, \mathrm{MsCl} \mathrm{CH}_{2} \mathrm{Cl}_{2}$, $0^{\circ} \mathrm{C}$ to room temp., overnight, $87 \%$.

Intermediate 25iii was used to obtain the corresponding imidazole $\mathbf{2 5 b}$ in two steps. After deprotection, amine 25c was reacted with sodium 2-chloroethanesulfonate in presence of sodium iodide and DIEA in DMF under microwave irradiation (scheme 11).

Scheme 11. Synthetic route to 25.

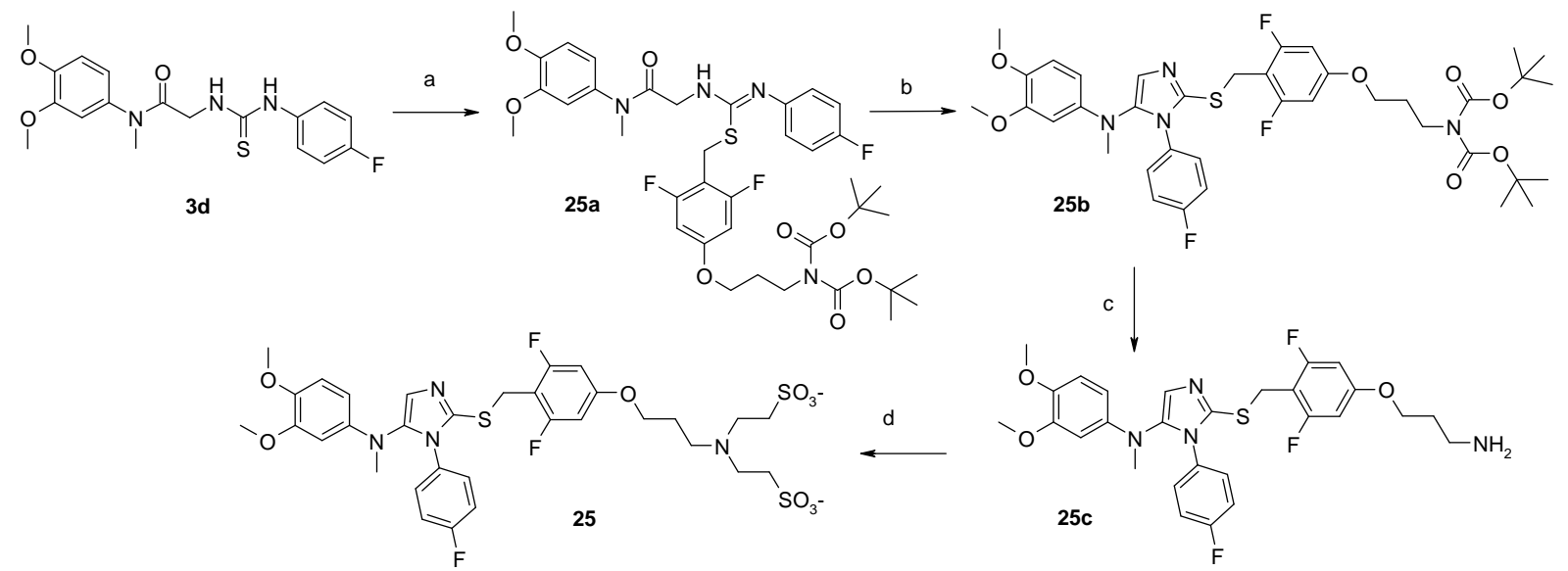

Reagents and conditions: (a) 25iii, DIEA, $\mathrm{CH}_{3} \mathrm{CN}$, room temp., overnight, $35 \%$ (b) 1propylphosphonic acid cyclic anhydride, DIEA, EtOAc, reflux, 48h, 62\% (c) TFA (10\%), $\mathrm{CH}_{2} \mathrm{Cl}_{2}$, room temp., 5h, 98\% (d) Sodium 2-chloroethanesulfonate, NaI, DIEA, DMF, $\mu \mathrm{W}$, $100^{\circ} \mathrm{C}, 2 \mathrm{~h}, 16 \%$. 
Compounds 26-30 were prepared in a similar way replacing glycine by alanine, or correctly protected lysine and glutamic acid (scheme 12).

Scheme 12. Synthetic route to $\mathbf{2 6 - 3 0}$.
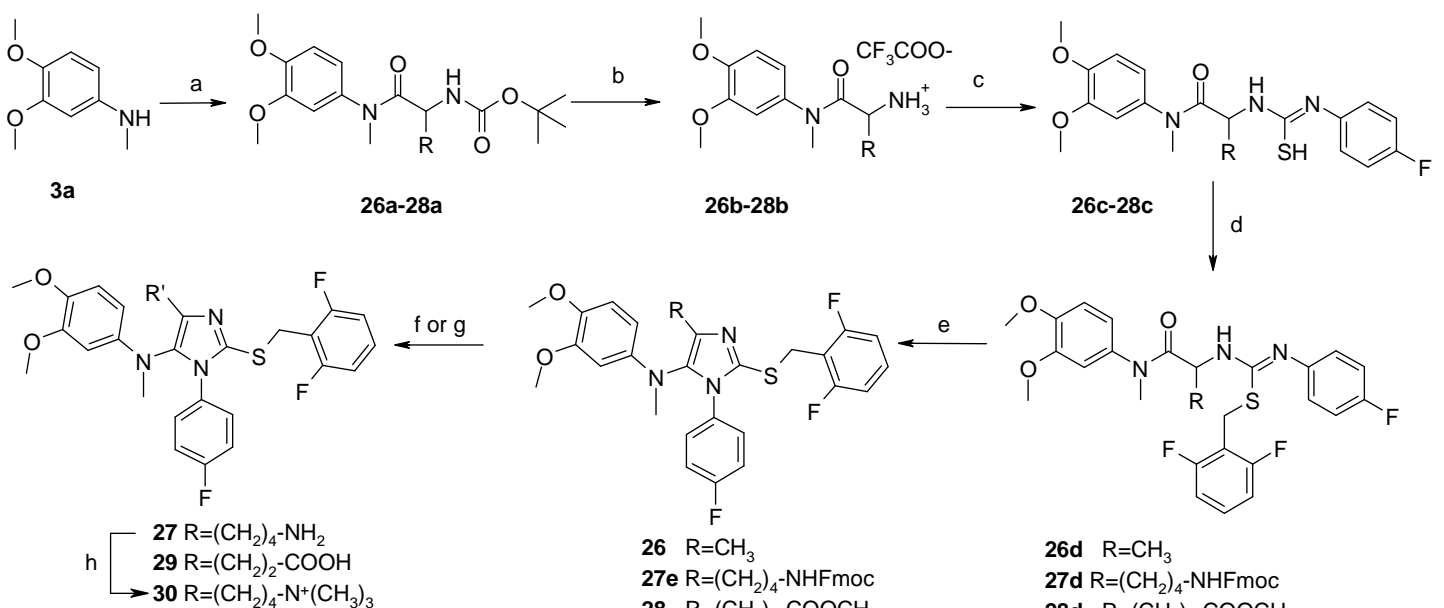

26b-28b

26c-28c
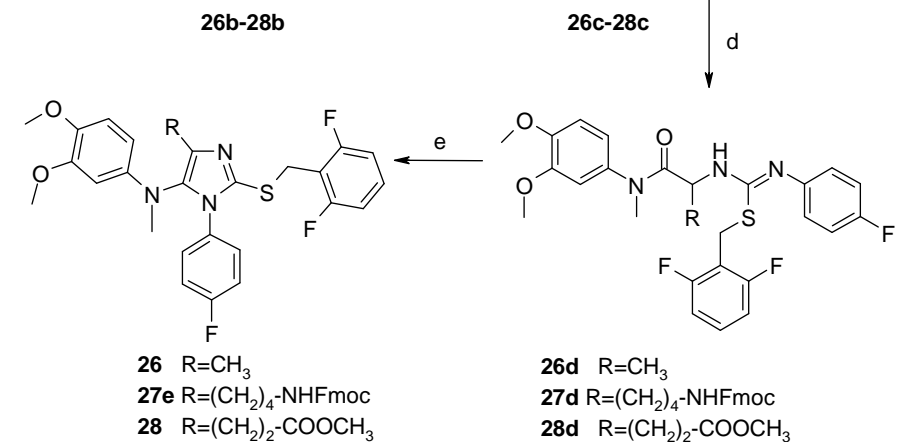

Reagents and conditions: (a) BocHN-CH(R)-COOH, 1-propylphosphonic acid cyclic anhydride,

DIEA, EtOAc, room temp., 30min-1h, 66-97\% (b) TFA (30\%)/ $\mathrm{CH}_{2} \mathrm{Cl}_{2}, 30 \mathrm{~min}, 100 \%$ (c) $4-$ fluorophenylisothiocyanate, TEA, EtOH, 5 min, 70-79\% (d) 2-bromoethyl-1,3-difluoro-benzene, $\mathrm{K}_{2} \mathrm{CO}_{3}$, Acetonitrile, room temp., overnight, 84-89\% (e) 1-propylphosphonic acid cyclic anhydride, DIEA, EtOAc, reflux (classical heating), 48h, 6-32\% (f) $\mathrm{NaOH} 1 \mathrm{~N}, \mathrm{MeOH}$, room temp., overnight, 93\% (g) piperidine, EtOAc, room temp., $60 \%$ (h) MeI, DIEA, Et ${ }_{2} \mathrm{O} / \mathrm{THF}$ (1/1), room temp., overnight, $20 \%$.

\section{RESULTS AND DISCUSSION}

All compounds were evaluated in vitro for their TGR5 agonist activity on both human and murine receptors in a CRE-driven luciferase reporter assays in TGR5-transfected HEK293 cells. Full agonist activity (efficacy $>80 \%$ measured relative to lithocholic acid $10 \mu \mathrm{M}$ ) was obtained for all active compounds. 


\section{Pharmacophore optimization}

TGR5 agonist activities on both human and murine receptors of compounds $\mathbf{1}$ and $\mathbf{2}$ are reported in Table 1. Surprisingly, compound $\mathbf{1}$ was shown to be completely inactive on both receptors. In contrast, compound $\mathbf{2}$ showed promising activity on the murine receptor.

Table 1. In vitro activity of compounds $\mathbf{1}$ and $\mathbf{2}$

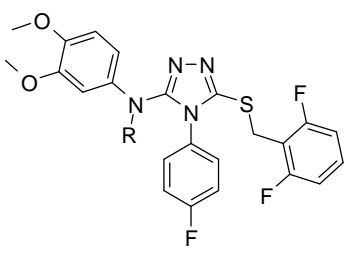

\begin{tabular}{|c|c|c|c|c|c|}
\hline & & \multicolumn{2}{|c|}{ hTGR5 } & \multicolumn{2}{|c|}{ mTGR5 } \\
\hline Example & $\mathrm{R}$ & & $(\mathrm{nM})$ & & $(\mathrm{nM})$ \\
\hline 1 & $\mathrm{H}$ & $\mathrm{NA}^{\mathrm{a}}$ & & $\mathrm{NA}^{\mathrm{a}}$ & \\
\hline 2 & $\mathrm{CH}_{3}$ & 4300 & [3800-4900] & 180 & [150-220] \\
\hline
\end{tabular}

$\mathrm{EC}_{50}$ values are reported with their $95 \%$ confidence intervals in brackets.

${ }^{a} \mathrm{NA}$ : not active (Emax $<10 \%$ at all concentrations up to $\left.30 \mu \mathrm{M}\right)$.

Replacing the triazole by an imidazole in $\mathbf{3}$ gave an interesting 2 log improvement of potency on both human and murine receptors (Table 2). We then decided to draw Structure Activity Relationships of this series by exploring the role of the substituants on the aromatics rings. SAR on the benzylic ring on the right-hand side of the molecules are described in the Table 2 . The 2,6-difluoro substitution of this phenyl ring appeared to be important for activity, especially on the murine receptor. Indeed, the $\mathrm{hEC}_{50} / \mathrm{mEC}_{50}$ ratio dropped from 44 for compound $\mathbf{3}$ to 2 for compound 5. 
Table 2. In vitro activity of compounds $\mathbf{2 - 6}$

\begin{tabular}{|c|c|c|c|c|c|}
\hline & & & hTGR5 & \multicolumn{2}{|c|}{ mTGR5 } \\
\hline Example & $\mathrm{X}$ & $\mathrm{R}$ & $\mathrm{EC}_{50}(\mathrm{nM})$ & \multicolumn{2}{|c|}{$\mathrm{EC}_{50}(\mathrm{nM})$} \\
\hline 2 & $\mathrm{~N}$ & & $4300 \quad[3800-4900]$ & 180 & {$[150-220]$} \\
\hline 3 & $\mathrm{CH}$ & & 35 [22-54] & 0.8 & {$[0.5-1.4]$} \\
\hline 4 & $\mathrm{CH}$ & & $128[81-200]$ & 12 & {$[5-32]$} \\
\hline 5 & $\mathrm{CH}$ & & $156[105-231]$ & 68 & {$[54-85]$} \\
\hline 6 & $\mathrm{CH}$ & & 299 [267-335] & 41 & [27-63] \\
\hline
\end{tabular}

$\mathrm{EC}_{50}$ values are reported with their 95\% confidence intervals in brackets.

Table 3 describes the SAR on the phenyl ring on the lower part of the molecule. As shown by the drastic decrease in potency for compound $\mathbf{8}$ and $\mathbf{9}$, more hindered group than fluorine are not tolerated at the para position, whether they are electrodonor or electroattractor. On the opposite, adding ortho and meta substitution on the para-fluorophenyl moiety showed interesting potency, with even a slight improvement with the compound $\mathbf{1 2}$ compared to compound $\mathbf{3}$. 
Table 3. In vitro activity of compounds $\mathbf{3 , 7 - 1 2}$

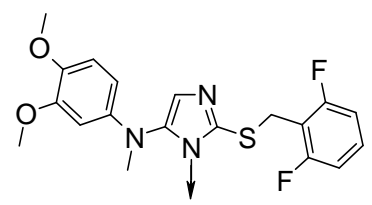

\begin{tabular}{|c|c|c|}
\hline & hTGR5 & mTGR5 \\
\hline Example & $\mathrm{EC}_{50}(\mathrm{nM})$ & $\mathrm{EC}_{50}(\mathrm{nM})$ \\
\hline 3 & 35 [22-54] & $0.8[0.5-1.4]$ \\
\hline 7 & 254 [207-312] & $5.1[4.2-6.1]$ \\
\hline 8 & 7745 [7135-8407] & 939 [731-1207] \\
\hline 9 & 900 [804-1008] & 366 [321-417] \\
\hline 10 & 35 [27-45] & $2.0[1.6-2.5]$ \\
\hline 11 & 47 [34-65] & 4.8 [3.7-6.3] \\
\hline 12 & $20[13-30]$ & $0.8[0.2-3.4]$ \\
\hline
\end{tabular}

$\mathrm{EC}_{50}$ values are reported with their 95\% confidence intervals in brackets.

Exploration of the SAR on the phenyl ring of the left-hand side of the molecule is described in Table 4. The 4,5-dimethoxy substitution appeared crucial for the compounds activity on TGR5, as removal of one or both methoxy groups (compounds $\mathbf{1 4}$ and 15) lead to a drastic drop of the potency (more than 100 fold on the murine receptor). 4-chloro-3-methoxy and 3,4-dichloro substitution lead to a decrease in potency, especially for the dichloro substitution on compound 16. Homologation of the 3,4-dimethoxyphenyl to 3,4-dimethoxybenzyl group lead to a less 
active compound (17). Whereas modification of the phenyl substitution was generally poorly tolerated, modification of the alkyl substitution of the extracyclic nitrogen showed only a moderate decrease of potency (compound 18). It is worth noting that we have tried several strategies to obtain the $\mathrm{N}$-desmethyl analog of compound $\mathbf{3}$ but were unable to isolate it, because of its high instability.

Table 4. In vitro activity of compounds 3, 13-19

\begin{tabular}{|c|c|c|c|c|}
\hline & & hTGR5 & \multicolumn{2}{|c|}{ mTGR5 } \\
\hline Example & $\mathrm{R}$ & $\mathrm{EC}_{50}(\mathrm{nM})$ & $\mathrm{EC}_{50}$ & $0(\mathrm{nM})$ \\
\hline 3 & $\mathrm{CH}_{3}$ & $35 \quad[22-54]$ & 0.8 & {$[0.5-1.4]$} \\
\hline 13 & $\mathrm{CH}_{3}$ & 885 [840-932] & 44 & [37-52] \\
\hline 14 & $\mathrm{CH}_{3}$ & 1106 [986-1240] & 141 & [120-165] \\
\hline 15 & $\mathrm{CH}_{3}$ & 994 [915-1079] & 91 & [73-113] \\
\hline 16 & $\mathrm{CH}_{3}$ & 750 [706-799] & 507 & {$[456-564]$} \\
\hline 17 & $\mathrm{CH}_{3}$ & 326 [290-365] & 40 & [24-66] \\
\hline 18 & $\begin{array}{c}-\mathrm{CH}_{2^{-}} \\
\mathrm{CH}=\mathrm{CH}_{2}\end{array}$ & 86 [44-169] & 7.7 & [6.6-9] \\
\hline 19 & $\mathrm{H}$ & $\mathrm{NA}^{\mathrm{a}}$ & $\geq 6000$ & \\
\hline
\end{tabular}

$\mathrm{EC}_{50}$ values are reported with their $95 \%$ confidence intervals in brackets

${ }^{\mathrm{a}} \mathrm{NA}$ : not active (Emax $<10 \%$ at all concentrations up to $\left.10 \mu \mathrm{M}\right)$. 


\section{Kinetophore positioning and optimization.}

Our strategy to obtain intestine-targeted TGR5 agonists was to introduce on our potent agonists a kinetophore group that would limit the intestinal absorption without effect on the TGR5 agonist activity of such compounds. The keystone of this strategy is the identification of a "mute" position where linking such groups would not impact the target interaction. Analysis of the SAR around compound $\mathbf{3}$ has demonstrated that the dimethoxy substitution on the left-hand side of the molecule was crucial and that the bottom of the molecule does not tolerate para-substitution by bigger groups than fluorine. We then decided to explore para substitution of the benzyl on the right-hand side of the molecule to add our kinetophore groups. The kinetophores were selected among structural groups making the compound large and/or polar.

In this paper, we will focus on ionic kinetophores, especially permanently ionized quaternary ammonium and sulfonate groups, which cannot be protonated in vivo (pKa $<-1)$.

Table 5 describes the TGR5 agonist activity of compound $\mathbf{3}$ and its analogs modified by substitution on the para position of the benzyl ring. First, we show here that this position can efficiently tolerate polar and hindered group, as all the compounds maintain a potency and full efficacy comparable to compound 3. Both positive and negative charges are well tolerated with better activities for the anionic compounds $(\mathbf{2 4}, \mathbf{2 5})$. 
Table 5. In vitro activity of compounds $\mathbf{3 , 2 0 - 2 5}$

\begin{tabular}{|c|c|c|c|}
\hline & & hTGR5 & mTGR5 \\
\hline Example & $\mathrm{R}$ & $\mathrm{EC}_{50}(\mathrm{nM})$ & $\mathrm{EC}_{50}(\mathrm{nM})$ \\
\hline 3 & & 35 [22-54] & $0.8[0.5-1.4]$ \\
\hline 20 & & $71 \quad[62-81]$ & $4.1 \quad[1.7-9.8]$ \\
\hline 21 & & 177 [146-214] & $7.5[6.2-9.1]$ \\
\hline 22 & & 260 [234-288] & 17 [11-27] \\
\hline 23 & & 238 [210-268] & 9.8 [8.6-11.2] \\
\hline 24 & & 24 [16-37] & $0.4[0.3-0.6]$ \\
\hline 25 & & 77 [41-144] & $0.3[0.3-0.4]$ \\
\hline
\end{tabular}

$\mathrm{EC}_{50}$ values are reported with their 95\% confidence intervals in brackets.

Finally, we explored the impact of a charged kinetophore moiety on the position 4 of the imidazole ring on potency. As can be seen in Table 6, a drastic loss of potency was observed for all compounds substituted on the position 4 of the imidazole (26-30). 
Table 6: In vitro activity of compounds $\mathbf{3 , 2 6 - 3 0}$

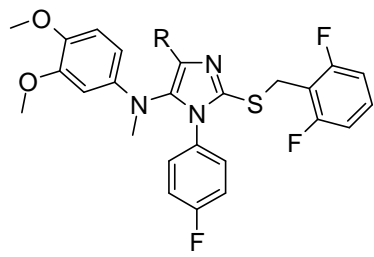

\begin{tabular}{cccrl}
\hline & & \multicolumn{1}{c}{ hTGR5 } & \multicolumn{1}{c}{ mTGR5 } \\
\hline Example & $\mathrm{R}$ & $\mathrm{EC}_{50}(\mathrm{nM})$ & \multicolumn{2}{c}{$\mathrm{EC}_{50}(\mathrm{nM})$} \\
& $-\mathrm{H}$ & $35[22-54]$ & 0.8 & {$[0.5-1.4]$} \\
3 & $-\mathrm{CH}_{3}$ & $337[304-373]$ & 7 & {$[6-8]$} \\
26 & $-\left(\mathrm{CH}_{2}\right)_{4}-\mathrm{NH}_{2}$ & $>4500$ & 119 & {$[98-145]$} \\
27 & $-\left(\mathrm{CH}_{2}\right)_{2}-\mathrm{COOMe}$ & $1113[992-1249]$ & 82 & {$[64-104]$} \\
28 & $-\left(\mathrm{CH}_{2}\right)_{2}-\mathrm{COOH}$ & $\mathrm{NC}^{\mathrm{a}}$ & 1935 & {$[1483-2526]$} \\
29 & $-\left(\mathrm{CH}_{2}\right)_{4}-\mathrm{N}^{+}\left(\mathrm{CH}_{3}\right)_{3}$ & $\geq 10000$ & 254 & {$[195-331]$} \\
30 &
\end{tabular}

$\mathrm{EC}_{50}$ values are reported with their $95 \%$ confidence intervals in brackets.

${ }^{\mathrm{a}} \mathrm{NC}$ : not calculated (Emax $<20 \%$ at all concentrations up to $\left.10 \mu \mathrm{M}\right)$.

The pharmocophore compound $\mathbf{3}$ and kinetophore-linked compounds 22, 23 and $\mathbf{2 4}$ showing interesting in vitro TGR5 activity, were then evaluated for physico-chemical and in vitro ADME properties.

As can be seen in Table 7, the kinetophore part of compounds 22-24 profoundly impacts physico-chemical properties: aqueous solubility of compounds 22-24 compared to $\mathbf{3}$ is largely improved and their lipophilicity decreased.

As polar surface area (PSA) has been described as a predictive parameter of the passive molecular transport through membranes and compound absorption in the GI tract, PSA as well as clogD and AlogP were calculated for compounds 22-24 using Pipeline Pilot ${ }^{\mathrm{TM}}$ (Accelrys) ${ }^{23-25}$.

In our case, the calculated $\left(\operatorname{cog} \mathrm{D}_{7.4}\right)$ was quite different from measured $\log \mathrm{D}_{7.4}$ for all the evaluated compounds (neutral, cationic and anionic). As can be seen in table 7, PSA is not 
impacted by the introduction of our cationic kinetophores ( $\mathbf{3}$ versus 22-23), because the charge is buried in the tetra-substituted ammonium, and neither a lone pair nor a hydrogen atom remains for hydrogen bonding. In contrast, introduction of the sulfonate group, a fully exposed charge leads to a much higher PSA (140 $\AA^{2}$ described as a threshold value to be usually poorly absorbed).

Cellular permeability was performed in Caco-2 monolayer permeability assay. In this assay, both cationic $(\mathbf{2 2}, \mathbf{2 3})$ and anionic $(\mathbf{2 4})$ compounds exhibited a very low permeability, much lower than that of our pharmacophore compound $3\left(\mathrm{P}_{\text {app }} \mathrm{A}-\mathrm{B} \leq 0.0810^{-6} \mathrm{~cm} \cdot \mathrm{s}^{-1}\right.$ and $\mathrm{P}_{\text {app }} \mathrm{A}-\mathrm{B}=5.32$ $10^{-6} \mathrm{~cm} \cdot \mathrm{s}^{-1}$ respectively). In this series, cellular permeability is not correlated with PSA. Indeed, compound $\mathbf{3}$ and cationic compounds $\mathbf{2 2}$ and $\mathbf{2 3}$ display the same PSA, but are highly different in term of permeability.

Incubation with mouse liver microsomes in vitro revealed that our compounds are metabolically instable $\left(t_{1 / 2}=1.2 \min\right.$ for compound 24). This result suggests a high first pass effect for these compounds that will further lower systemic exposure in addition to a low intestinal permeability. 
Table 7. In vitro ADME evaluation of kinetophore-coupled compounds

\begin{tabular}{|c|c|c|c|c|}
\hline Compound & 3 & 22 & 23 & 24 \\
\hline kinetophore & $\varnothing$ & $\stackrel{1}{N^{+}-}$ & $-\mathrm{N}^{+} \mathrm{L}^{\mathrm{N}}$ & $\begin{array}{c}S^{\prime} \\
-S^{\prime \prime} \\
0^{\prime}\end{array}$ \\
\hline \multicolumn{5}{|c|}{ Calculated parameters ${ }^{1}$} \\
\hline $\operatorname{cLog} \mathrm{D}$ & 6.63 & 5.93 & 5.36 & 4.15 \\
\hline $\operatorname{PSA}\left(\AA^{2}\right)$ & 65 & 65 & 73 & 140 \\
\hline \multicolumn{5}{|c|}{ Measured parameters } \\
\hline Aqueous Solubility $(\mu \mathrm{M})$ & 6.3 & $>200$ & $>200$ & $>200$ \\
\hline $\log \mathrm{D}(7.4)$ & 3.5 & 1.0 & 0.9 & 0.8 \\
\hline $\begin{array}{c}\mathrm{P}_{\text {app }} \mathrm{A}-\mathrm{B}{ }^{\mathrm{a}} \\
\text { recovery }(\%)\end{array}$ & $\begin{array}{l}5.32^{b} \pm 0.94 \\
84.4 \pm 6.9 \%\end{array}$ & $\begin{array}{l}0.08 \pm 0.02^{\mathrm{c}} \\
69.8 \pm 8.7 \%\end{array}$ & $\begin{array}{l}0.016 \pm 0.005 \\
69.3 \pm 1.2 \%\end{array}$ & $\begin{array}{l}0.031 \pm 0.011 \\
80.1 \pm 4.2 \%\end{array}$ \\
\hline $\begin{array}{c}\mathrm{P}_{\text {app }} \mathrm{B}-\mathrm{A}^{\mathrm{a}} \\
\text { recovery }(\%)\end{array}$ & $\begin{array}{c}5.47^{\mathrm{b}} \pm 1.29 \\
106.4 \pm 19.7 \%\end{array}$ & $\begin{array}{c}0.24 \pm 0.03^{\mathrm{c}} \\
93.4 \pm 0.7 \%\end{array}$ & $\begin{array}{c}0.22 \pm 0.06 \\
99.6 \pm 0.4 \%\end{array}$ & $\begin{array}{c}19 \pm 1.91 \\
101.8 \pm 3.5 \%\end{array}$ \\
\hline Efflux ratio & 1 & $3.1^{\mathrm{c}}$ & 14 & 636 \\
\hline $\begin{array}{c}\text { Microsomal stability } \\
\mathrm{t}_{1 / 2}(\mathrm{~min})\end{array}$ & 0.7 & 10.6 & N.D. & 1.2 \\
\hline $\begin{array}{c}\text { Microsomal stability } \\
\mathrm{Cl}_{\text {int }}(\mu \mathrm{L} / \mathrm{min} / \mathrm{mg} \text { proteins })\end{array}$ & 1287 & 264 & N.D. & 1211 \\
\hline
\end{tabular}

${ }^{1}$ calculated parameters using Pipeline Pilot ${ }^{\mathrm{TM}}$ (Accelrys)

${ }^{a}$ Cell membrane permeability assessed on a Caco-2 cell monolayer. "A-B" indicates the transport from apical side to basolateral side "B-A" indicates the transport from basolateral side to apical side. Compounds were tested at $10 \mu \mathrm{M}$. Permeability is expressed in $10^{-6} \mathrm{~cm} \cdot \mathrm{s}^{-1}$ Permeability classification: low : $\mathrm{P}_{\text {app }}<2 \times 10^{-6} \mathrm{~cm} \cdot \mathrm{s}^{-1}$; high : $\mathrm{P}_{\text {app }}>20 \times 10^{-6} \mathrm{~cm} \cdot \mathrm{s}^{-1}$.

${ }^{\mathrm{b}}$ Compound tested at $5 \mu \mathrm{M}$

${ }^{\mathrm{c}}$ Compound tested as an iodide (ie compound 21)

Compounds 22 and 24, bearing interesting in vitro activity and very low permeability were chosen for further in vivo pharmacokinetic and pharmacodynamic studies in C57B16 mice.

The time required by the drug to reach ileum and colon containing the highest density of target L-cells ${ }^{6}$ after oral dosing was unknown. Therefore, compounds 22 and $\mathbf{2 4}$ were administered orally at three consecutive time-points (T-6h, T-4h, T-2h; $3 \times 20 \mathrm{mg} / \mathrm{kg}$ ) to ensure the complete 
exposure of the GI tract. In order to test the ability of compound 22 to promote GLP-1 secretion, mice were treated with vehicle or compound 22 as described, prior to an oral glucose $(2 \mathrm{~g} / \mathrm{kg})$ or water load. Blood samples were collected 15 minutes later to measure active GLP-1 plasma concentrations. In addition, sitagliptin $(25 \mathrm{mg} / \mathrm{kg})$ was given orally 1 hour prior to blood sample collection to prevent GLP-1 degradation. As expected, glucose increased GLP-1 concentrations in vehicle treated mice (Figure 1, Veh+Water vs Veh+Glc). As expected, compound 22 further enhanced the glucose-induced GLP-1 secretion compared to vehicle (Figure 1, Veh+Glc vs 22+Glc). Interestingly, compound 22 induced a 4 fold increase in active GLP-1 concentrations even in absence of glucose challenge compared to vehicle treated mice (Figure 1, Veh+Water $v s$ 22+Water). Thus, compound $\mathbf{2 2}$ by itself appears to be a potent GLP-1 secretagogue in vivo even in absence of glucose challenge.

In the same experimental setting, 24 lead to a 2.6 fold increase in GLP-1 concentrations compared to the vehicle treated group in absence of glucose challenge (Figure 2). To evaluate the impact of the kinetophore in this approach, the effect of naked pharmacophore $\mathbf{3}$ was measured in vivo at $15.5 \mathrm{mg} / \mathrm{kg}$, i.e. the same molar quantity as $20 \mathrm{mg} / \mathrm{kg}$ of compound $\mathbf{2 4}$. No difference with vehicle could be detected (data not shown). This contrasts interestingly with what has been observed on kinetophore bearing compounds, and illustrates the necessity of controlling absorption of our TGR5 agonists, to reach the distal section of the gut, where most of L-cells are located. 


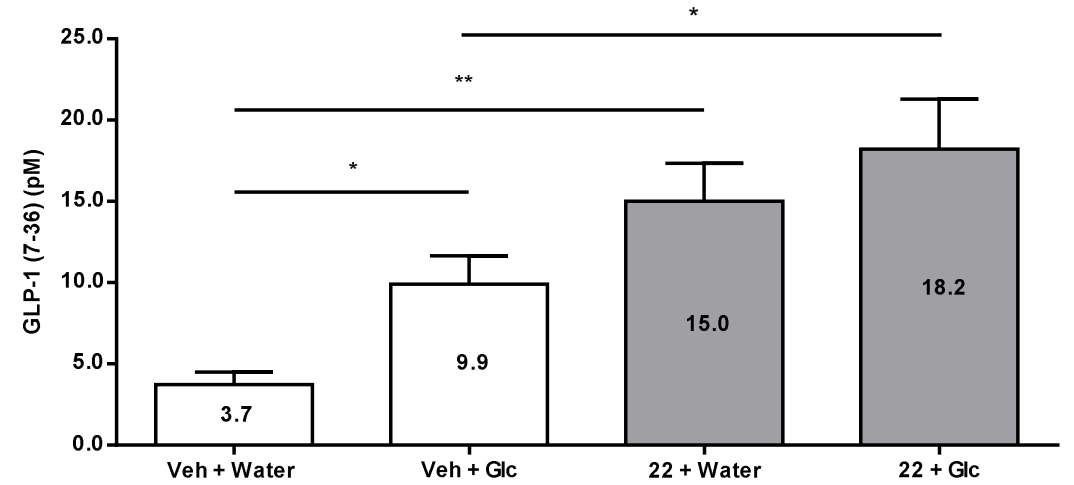

Figure 1. In vivo GLP-1 secretion in C57B16 mice. Vehicle (white bars) or compound 22 (grey bars) were administered to mice at 3 consecutive time-points (T-6h, T- $4 \mathrm{~h}, \mathrm{~T}-2 \mathrm{~h}, 3 \times 20 \mathrm{mg} / \mathrm{kg}$ ) before challenge with a bolus of water or glucose (T0). All groups received sitagliptin (25 $\mathrm{mg} / \mathrm{kg}$ ) $45 \mathrm{~min}$ prior to blood sample collection $(\mathrm{T}+15 \mathrm{~min})$. Mean $\pm \mathrm{SEM}(\mathrm{n}=6 /$ group$) . *$ $\mathrm{p}<0.05, * * \mathrm{p}<0.01$ (ANOVA and Holm-Sidak test). Veh $=$ vehicle $($ Tween $0.1 \%)$. Glc $=$ glucose $(2 \mathrm{~g} / \mathrm{kg}) . \mathbf{2 2}=$ Compound 22 in Tween $0.1 \%(3 \times 20 \mathrm{mg} / \mathrm{kg})$.

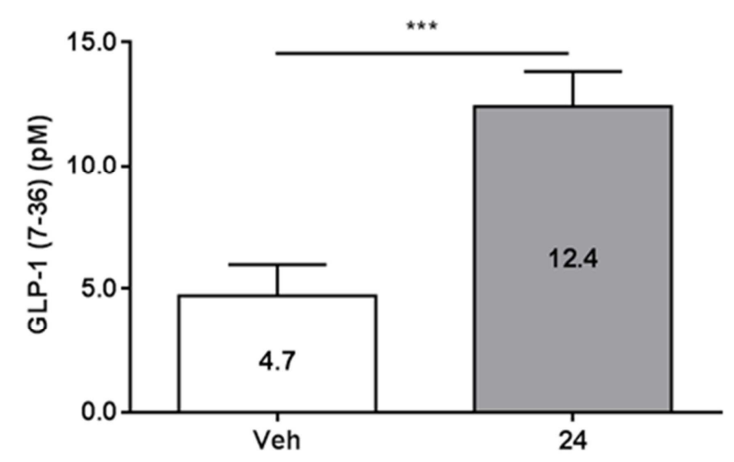

Figure 2. In vivo GLP-1 secretion in C57B16 mice. Vehicle (white bars) or compound 24 (grey bars) were administered to mice at 3 time-points (T-6h, T-4h, T-2h, 3 x $20 \mathrm{mg} / \mathrm{kg}$ ) before blood collection (T0) to measure active GLP-1 plasma concentrations. All groups received sitagliptin $(25 \mathrm{mg} / \mathrm{kg}$ ) 45min prior to blood sampling. Mean \pm SEM ( $\mathrm{n}=8 /$ group). *** $\mathrm{p}<0.001$ (Student's t test) 
Then, plasma AUC, as well as liver and gallbladder exposure were measured in mice dosed orally with compounds $\mathbf{2 2}$ and $\mathbf{2 4}$ at $20 \mathrm{mg} / \mathrm{kg}$. As expected from the low in vitro permeability of compounds 22 and 24, fecal recovery was quantitative (Table 8). Micromolar concentrations were reached after 4 hours in the gallbladder, while 100 -fold lower $C_{\max }$ was measured in plasma. Of note, the relatively high concentration in gallbladder results from the biliary excretion of only a small fraction $(<0.1 \%$ for $\mathbf{2 4})$ of administered compound.

Table 8. Pharmacokinetic parameters of kinetophore-coupled compounds 22 and 24 in C57B16 mice

\begin{tabular}{crr}
\hline Compound & $\mathbf{2 2}$ & $\mathbf{2 4}$ \\
\hline$[\mathrm{C}]_{\text {plasma }} \max (\mathrm{nM})$ & 100 & 102 \\
{$[\mathrm{C}]_{\text {plasma }} \max (\mathrm{ng} / \mathrm{mL})$} & 58 & 63 \\
$\mathrm{~T}_{\text {max plasma }}(\mathrm{min})$ & 15 & 45 \\
$\mathrm{AUC}(\mathrm{ng} \cdot \min / \mathrm{mL})$ & 2909 & 5774 \\
$\mathrm{t}_{1 / 2}(\min )$ & 97 & 317 \\
Liver $_{\max }(\mathrm{nM})$ & $\mathrm{nd}$ & 385 \\
Gallbladder $(\mathrm{tissue}$ and & 9028 & 10980 \\
content) $\mathrm{C}_{\max }(\mathrm{nM})$ & 88 & 100 \\
Fecal recovery $(\%)^{\mathrm{a}}$ &
\end{tabular}

$\mathrm{n}=3$ mice/time; male C57B16/J mice. Compounds were administered orally $(20 \mathrm{mg} / \mathrm{kg}$, formulated in Tween $0.1 \%$ ).

${ }^{\text {a }}$ Feces collected 24 hours after compound dosing $(20 \mathrm{mg} / \mathrm{kg})$. Parent compound was extracted with organic solvent and analyzed quantitatively using mass spectrometry. 
Intestinal exposure was then measured for compound 24. Very interestingly, the results of the exposure of the different sections of GI tract showed that the targeted distal sections (ileum and colon) were maximally exposed by compound 248 hours after oral dosing (Figure 3).

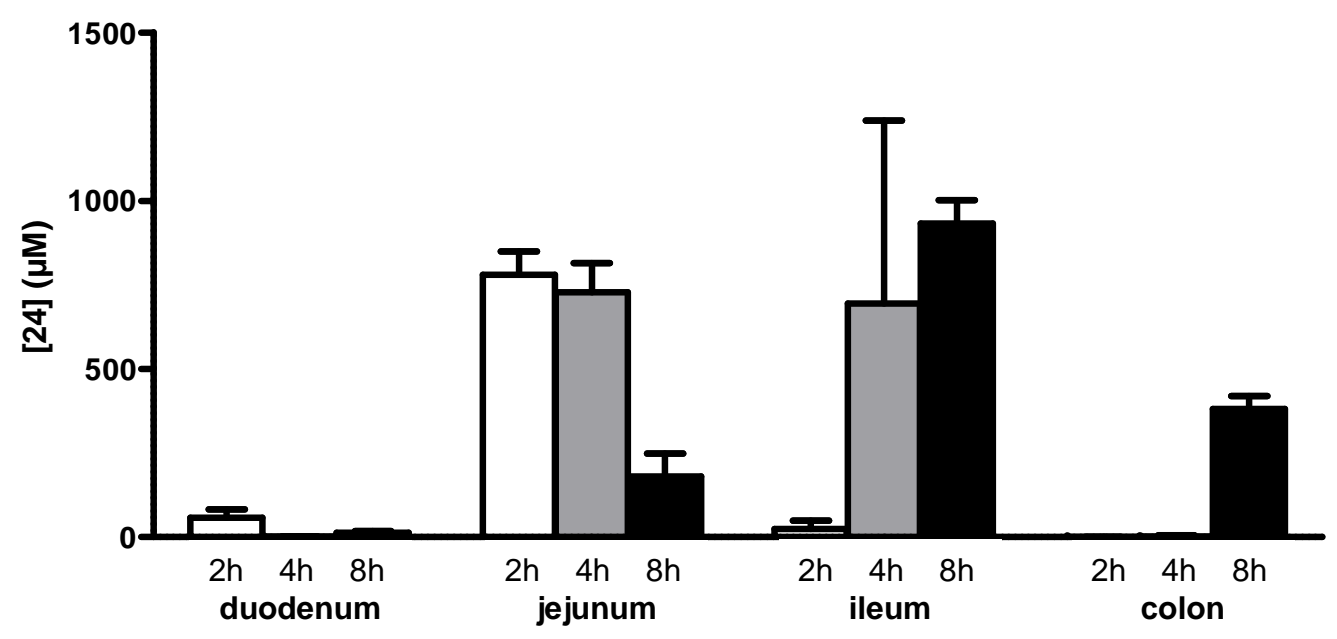

Figure 3. Time-course of compound $\mathbf{2 4}$ concentrations in duodenum, jejunum, ileum and colon of C57B16 mice, after a single oral administration $(20 \mathrm{mg} / \mathrm{kg})$. Mean $\pm \mathrm{SEM}(\mathrm{n}=3$ mice/time $)$.

In light of the results obtained concerning the intestinal exposure by compound $\mathbf{2 4}$, we next explored the effect of the time elapsed between oral dosing and the GLP-1 secretion assay. As maximal GLP-1 secretion is expected when TGR5 is activated in distal sections of the GI tract, we compared GLP-1 secretion at two time-points after oral load by compound $\mathbf{2 4}$. Consistent with the pharmacokinetics observed in the intestine, a 3.6 fold and a 10 fold increase in active GLP-1 concentrations were observed respectively 4 hours and 7 hours after administration of 24 (Figure 4). 


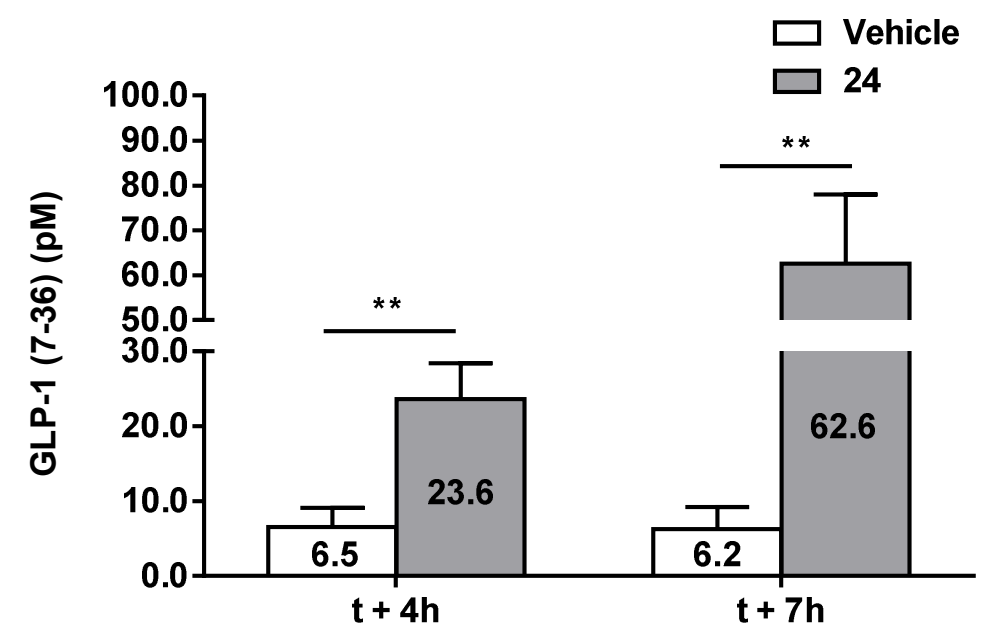

Figure 4. In vivo GLP-1 secretion in C57B16 mice. Vehicle (white bars) or compound 24 (grey bars) were administrated to mice 4 hours $(t+4 h)$ or 7 hours $(t+7 h)$ before blood collection for active GLP-1 plasma concentration measurement. All groups received sitagliptin $(25 \mathrm{mg} / \mathrm{kg}) 45$ min prior to blood sampling. Mean \pm SEM ( $n=6 /$ group). $* * \mathrm{p}<0.01$ (Student's $\mathrm{t}$ test). Vehicle $=$ Tween $0.1 \% .24=$ Compound $\mathbf{2 4}$ in Tween $0.1 \%(20 \mathrm{mg} / \mathrm{kg})$.

Then, C57B16 mice were orally treated with increasing doses of $\mathbf{2 4}$ and plasma active GLP-1 concentrations were measured 8 hours post-dosing. Compound 24 induced a dose-dependent GLP-1 secretion (Figure 5A). Gallbladder relaxation, described in rodent treated with both bile acid derivatives and non-steroid small TGR5 agonist molecules ${ }^{26,27}$, was assessed by gallbladder volume measurement in fasted mice 8 hours after a single oral administration of vehicle or $\mathbf{2 4}$ at increasing dose. Interestingly, a high GLP-1 secretion (6-fold increase in active GLP-1 plasma concentrations) was obtained at a dose $(5 \mathrm{mg} / \mathrm{kg})$ that did not modify gallbladder volume, suggesting that in these conditions gallbladder exposure is not sufficient to trigger the pharmacological response of the gallbladder (Figure 5B). Gallbladder motility was then studied by gallbladder volume measurement in fasted and re-fed conditions at the highest tested dose (20 $\mathrm{mg} / \mathrm{kg}$ ). In this experiment, we showed that gallbladder volume is not significantly increased by 
$\mathbf{2 4}$ both in fasted and re-fed conditions. We showed moreover that compound $\mathbf{2 4}$ does not disrupt food stimulated gallbladder emptying and motility (ejection fraction of 30 and $25 \%$ respectively for vehicle and compound 24). (Figure 5C) Thus the ratio between the lowest active dose (5 $\mathrm{mg} / \mathrm{kg}$ ) and the highest dose that does not modify gallbladder motility $(20 \mathrm{mg} / \mathrm{kg})$ defines a therapeutic window of 4 . 
A

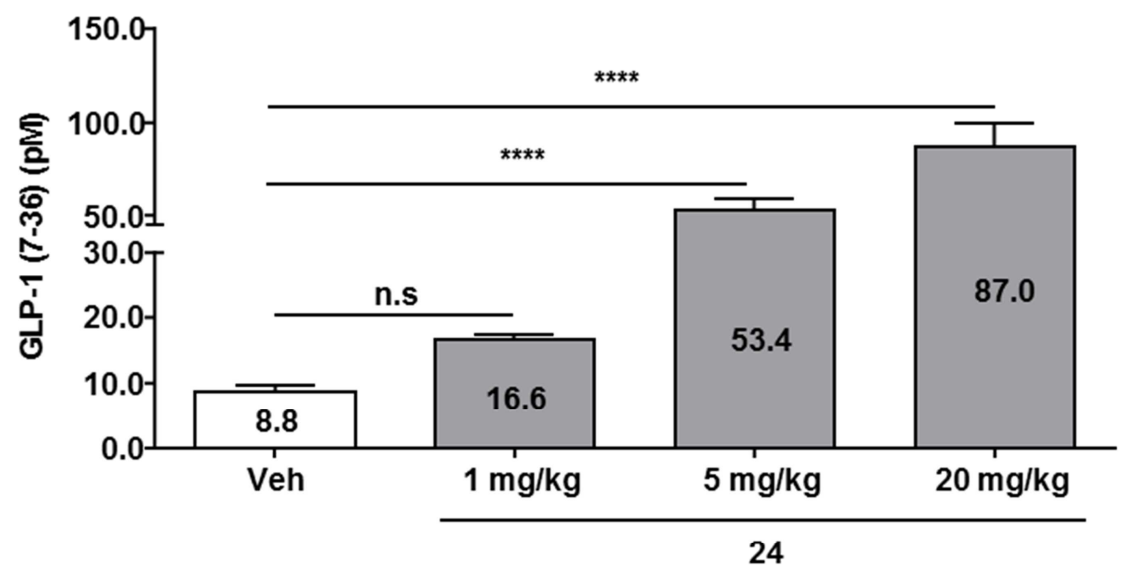

B

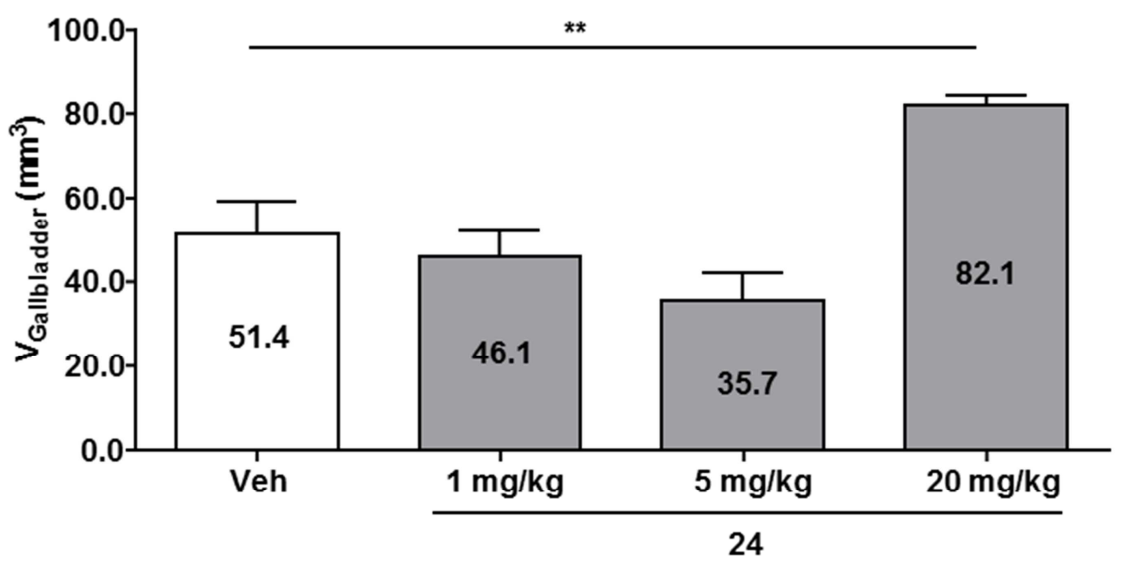

C

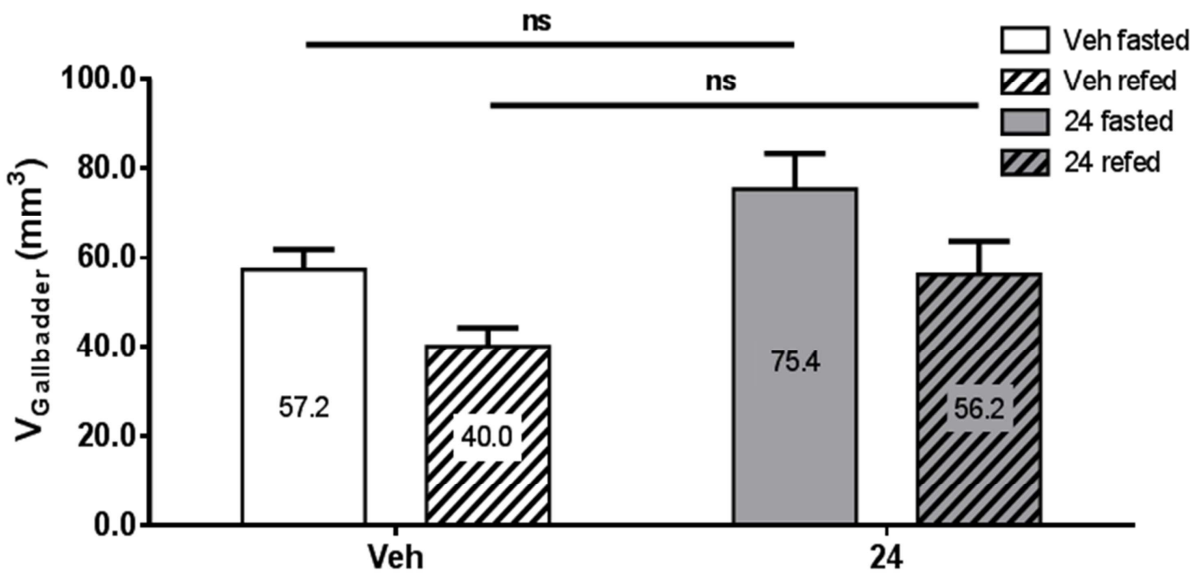


Figure 5. In vivo dose response effect of compound 24 in C57B16 mice. A) GLP-1 secretion after oral administration of Vehicle (white bar) or $\mathbf{2 4}$ (grey bars) 8 hours prior to blood sample collection for active GLP-1 plasma concentration measurement. All groups received sitagliptin $(25 \mathrm{mg} / \mathrm{kg}) 45 \mathrm{~min}$ prior to blood sampling. Mean \pm SEM ( $\mathrm{n}=6 /$ group). $* * * * \mathrm{p}<0.0001$ (ANOVA - Dunnet test). B) Gallbladder volume in fasted mice 8 hours after oral administration of compound 24. Mean \pm SEM ( $n=6 /$ group). $* * \mathrm{p}<0.01$ (ANOVA - Dunnet test). C) Gallbladder volume in fasted (6 hours) and re-fed (fasted 4 hours then re-fed for 2 hours) after oral administration of compound $\mathbf{2 4}(20 \mathrm{mg} / \mathrm{kg})$ or vehicle. Mean \pm SEM ( $\mathrm{n}=6 /$ group $)$. ANOVA Tukey test. Veh $=$ Vehicle $($ Tween $0.1 \%) .24=$ Compound 24 in Tween $0.1 \%$.

We have shown that compound $\mathbf{2 4}$ is mainly retained in the intestine and triggers GLP-1 secretion in a physiological context, in a dose dependent manner. Next, the GLP-1 secretagogue effect of compound $\mathbf{2 4}$ was tested in a pathological context, namely in C57BL6 mice rendered obese and insulin-resistant by feeding a high fat diet (HFD) for 10 weeks. Interestingly, a 20 $\mathrm{mg} / \mathrm{kg}$ dose of $\mathbf{2 4}$ increased active GLP-1 4-fold in HFD-fed mice (Figure 6). This increase in GLP-1 secretion (4-fold) in HFD-fed mice was lower than the one observed in lean mice at the same dose (10-fold, figure 5A).

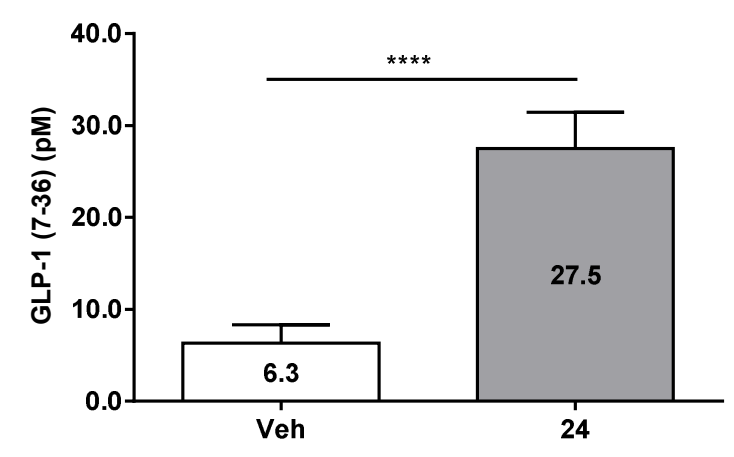


Figure 6. In vivo GLP-1 secretion in C57B16 mice fed a HFD. Vehicle (white bars) or compound $\mathbf{2 4}$ (grey bars) were administrated to mice 8 hours prior to blood sample collection for active GLP-1 plasma concentration measurement. All groups received sitagliptin $(25 \mathrm{mg} / \mathrm{kg}) 45$ min prior to blood sampling. Mean \pm SEM ( $n=10$ /group). $* * * * p<0.0001$ (Student's t test). Veh $=$ vehicle $($ Tween $0.1 \%) . \mathbf{2 4}=$ Compound $\mathbf{2 4}$ in Tween $0.1 \%(20 \mathrm{mg} / \mathrm{kg})$.

In order to evaluate the effect of compound $\mathbf{2 4}$ on glucose homeostasis, HFD fed mice treated with a single dose of compound $\mathbf{2 4}$ were submitted to an oral glucose tolerance test 7 hours later. Compound 24 did not modify basal glycemia (T0 in the OGTT test, Figure 7). Interestingly, after a glucose challenge, glucose concentrations returned faster to the basal state in 24-treated mice compared to controls as assessed by the time-course and AUC calculation (Figure 7). Thus, the GLP-1 secretion induced by compound $\mathbf{2 4}$ translates into improved glucose tolerance in a pathological model.

A

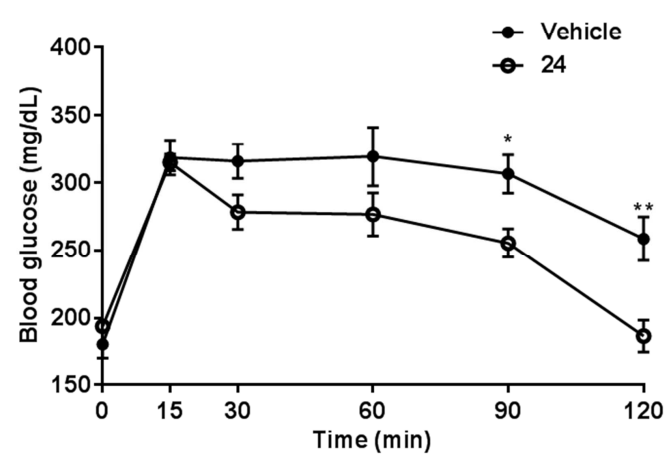

B

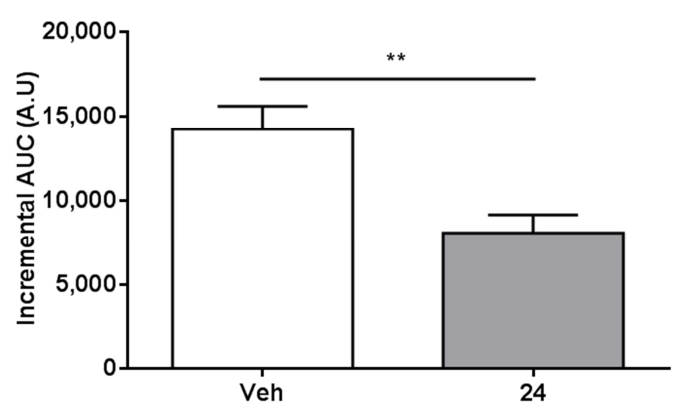

Figure 7: Effect of compound 24 administration on oral glucose tolerance test in HFD fed C57BL6 mice. Obese, insulin-resistant mice were treated with Vehicle or 24. (Veh = vehicle (Tween $0.1 \%) .24=$ Compound $24(20 \mathrm{mg} / \mathrm{kg})$ in Tween $0.1 \%) .7$ hours later, mice were challenged with an oral bolus of glucose $(4 \mathrm{~g} / \mathrm{kg})$ and glucose measured at the indicated time- 
points. A) Glucose excursion curve. B) Incremental area under curve (AUC), expressed as arbitrary unit (A.U.). Mean \pm SEM ( $\mathrm{n}=8$ /group). $* \mathrm{p}<0.05, * * \mathrm{p}<0.01$ (Student's $\mathrm{t}$ test)

It was recently reported that functional TGR5 appears to be mostly located on the basolateral side of enteroendocrine L-cells, suggesting that crossing the intestinal epithelium is required before bile acids or other TGR5 agonists can elicit a GLP-1 secretory response. Under these conditions, luminally-restricted TGR5 agonists would not induce a strong GLP-1 secretion in vivo. ${ }^{28}$ Interestingly, despite very low permeability in Caco-2 enterocytes in culture and a concordant poor systemic exposure, compound $\mathbf{2 4}$ was able to trigger a strong in vivo GLP-1 secretion. As can be seen in Table 7, 24 undergoes a very high active efflux (efflux ratio > 600) in the permeability assay on Caco- 2 cells, explaining the very low absorption through enterocytes. This also suggests that, in the much less abundant enteroendocrine L-cells which are devoid of efflux mechanisms, a significant fraction of the compound could cross cell membranes and activate TGR5 on basolateral side without contributing to systemic absorption. A useful consequence of its low intestinal absorption is that $\mathbf{2 4}$ reaches the distal intestine where TGR5 expression is maximal, and triggers GLP-1 secretion.

CONCLUSIONS. Modification of a potent agonist of TGR5 to decrease intestinal absorption without impacting membrane permeation in target cells, was proven to be a valid strategy to activate enteroendocrine L-cells located in the lower intestinal tract, while creating a potency window between the efficacious dose measured on glucose tolerance and the dose triggering gallbladder response. Compound $\mathbf{2 4}$ exhibits high in vitro potency and in vivo GLP-1 
secretagogue effect that translates into an improved glucose tolerance in a pathological murine model of obesity/insulin-resistance. Thanks to a fine-tuned pharmacokinetic behavior, this TGR5 agonist displays attracting in vivo efficacy and safety.

Further biological evaluations are on-going to explore in details the mechanisms underlying the effects of compound 24 (BDM72881) $)^{29}$ and support the therapeutic potential of topical intestinal TGR5 agonists for treatment of type 2 diabetes.

\section{EXPERIMENTAL SECTION}

In vitro TGR5 Assay. TGR5 activation by compounds and subsequent increase in intracellular cAMP were evaluated using a luciferase reporter gene assay. Human embryonic kidney (HEK) 293 cells were transiently co-transfected with pCMV tag4b-TGR5h (to determine hTGR5 activation) or pCMV AC6-TGR5m (to determine mTGR5 activation) expression plasmids and the pCRE TA-Luciferase reporter plasmid using the JET PEI reagent (Polyplus transfection). Transfected cells were seeded in 96-well plates and incubated overnight with the compounds at increasing concentrations in duplicate. Lithocholic acid (LCA) at $10 \mu \mathrm{M}$ was used as a positive reference compound. The cAMP-dependent luciferase expression was followed using the BrightGlo reagent according to the manufacturer (Promega) instructions. Luminescence was measured with a Mithras plate reader (Berthold). Data were expressed as percentage of the $10 \mu \mathrm{M}$ LCA value and $\mathrm{EC}_{50}$ values were calculated using XL fit 5 software or GraphPad Prism 5. Concentration-response curves were fitted by a nonlinear regression analysis to a 4 parameters logistic equation. 
LC-MS/MS ADME methods. Chromatography was performed using a UPLC system, an Acquity I-Class (Waters). Separation was achieved on a Waters Acquity BEH C18 column (2.1 $\mathrm{mm} \times 50 \mathrm{~mm}, 1.7 \mu \mathrm{m})$. The autosampler and column oven temperatures were $10^{\circ} \mathrm{C}$ and $40^{\circ} \mathrm{C}$ respectively and the sample injection volume was $1 \mu \mathrm{L}$. The mobile phase consisted in $0.1 \%$ Formic Acid (FA) in water as solvent A and $0.1 \%$ FA in acetonitrile as solvent $\mathrm{B}$ at a flowrate of $600 \mu \mathrm{L} / \mathrm{min}$. The gradient was as follows: $0-0.2 \min (98 \% \mathrm{~A}$ and $2 \% \mathrm{~B}), 2-2.5 \min (2 \% \mathrm{~A}$ and 98\%B), $2.6 \min (98 \% \mathrm{~A}$ and 2\%B), 4 min (98\%A and 2\%B). Gradient step was linear.

Mass spectrometry was performed using a Xevo TQD (Waters Corporation) mass spectrometer. The detection of analytes was achieved by electrospray ionization (ESI) in the positive mode with the appropriate MRM transition. Other mass spectrometer settings were: capillary voltage and cone voltage were optimized for each compound, desolvation temperature $600^{\circ} \mathrm{C}$ at a gas flow of $1200 \mathrm{~L} / \mathrm{h}$ and cone gas flow $50 \mathrm{~L} / \mathrm{h}$. The LC-MS/MS instrument was controlled by MassLynx software (Waters).

Solubility/LogD measurements. $10 \mu \mathrm{L}$ of a $10 \mathrm{mM}$ solution in DMSO of the compound are diluted either in $490 \mu \mathrm{L}$ of PBS pH 7.4 or in organic solvent $\mathrm{MeOH}$ in a $700 \mu \mathrm{L}$-microtube (in triplicate). The tubes are gently shaken $24 \mathrm{~h}$ at room temperature, then centrifuged for 5 minutes at $4000 \mathrm{rpm}$. The mixtures are filtered over $0.45 \mu \mathrm{m}$ filters (Millex-LH Millipore). $10 \mu \mathrm{L}$ of sample are diluted in $490 \mu \mathrm{L}$ of $\mathrm{MeOH}$. The solubility is determined by the ratio of mass signal area PBS/ organic solvent.

$40 \mu \mathrm{L}$ of a $10 \mathrm{mM}$ solution in DMSO of the compound were diluted in $1.960 \mathrm{~mL}$ of a $1 / 1$ octanol /PBS at pH 7.4 mixture. The mixture was gently shaken $2 \mathrm{~h}$ at room temperature. $10 \mu \mathrm{L}$ of each phase was diluted in $490 \mu \mathrm{L}$ of $\mathrm{MeOH}$ and analyzed by LC-MS/MS. Each compound is tested in 
triplicate. Log D was determined as the logarithm of the ratio of concentration of product in octanol and PBS respectively, determined by mass signals.

Microsomal stability. Male mouse (CD-1) liver microsomes (BD Gentest) were used. All incubations were performed in duplicate in a shaking water bath at $37{ }^{\circ} \mathrm{C}$. The incubation mixtures contained $1 \mu \mathrm{M}$ compound with $1 \%$ methanol used as a vehicle, mouse liver microsomes ( $0.3 \mathrm{mg}$ of microsomal protein per $\mathrm{mL}$ ), $5 \mathrm{mM} \mathrm{MgCl} 2,1 \mathrm{mM}$ NADP, $5 \mathrm{mM}$ glucose 6-phosphate, $0.4 \mathrm{U} \cdot \mathrm{mL}^{-1}$ glucose 6-phosphate dehydrogenase, and $50 \mathrm{mM}$ potassium phosphate buffer $(\mathrm{pH} 7.4)$ in a final volume of $0.5 \mathrm{~mL}$. Aliquots were removed at 5, 10, 20, 30, and $40 \mathrm{~min}$ after microsomes addition, and the reaction was stopped by adding four volumes of ice-cold acetonitrile containing $200 \mathrm{nM}$ of internal standard. The samples were centrifuged for $10 \mathrm{~min}$ at $10000 \mathrm{rpm}$ and the supernatants were transferred in matrix tubes for LC-MS: MS analysis. Each compound was quantified by converting the corresponding analyte/internal standard peak area ratios to percentage drug remaining, using the initial ratio values in control incubations as $100 \%$. Propranolol, known as a high hepatic clearance drug in rodents, was used as a quality-control compound for the microsomal incubations. In vitro intrinsic clearance $\left(\mathrm{Cl}_{\text {int }}\right.$ expressed as $\mu \mathrm{L} / \mathrm{min} / \mathrm{mg}$ ) was calculated according to: the following formula : $\mathrm{Cl}_{\text {int }}=$ dose/ $\mathrm{AUC}_{\infty}$, where dose is the initial amount of drug in the incubation mixture $(1 \mu \mathrm{M})$ and $\mathrm{AUC}_{\infty}$ is the area under the concentration versus time curve extrapolated to infinity. The slope of the linear regression from log percentage remaining versus incubation time relationships (-k) was used in the conversion to in vitro $\mathrm{t}_{1 / 2}$ values by: $\mathrm{t}_{1 / 2}=-\ln (2) / \mathrm{k}$.

Caco-2 permeation assay ${ }^{30} .0 .4 \times 10^{5}$ Caco-2 Cells (ATCC No. HTB-37), at passage 28, were seeded on $25 \mathrm{~cm}^{2}$ plastic flask and changed every second days with complete medium containing high glucose Dulbecco's Modified Eagle's Medium (DMEM) with L-glutamine supplemented 
by $10 \%$ of Foetal Calf/Bovine Serum, $1 \%$ of non-essential amino acids without L-glutamine. The paracellular barrier characteristics of Caco-2 cells monolayer was monitored using measurement of the permeability to the non-permeant fluorescent molecule, Lucifer Yellow (LY). The permeability to Lucifer yellow values $\left(<1 \times 10^{-6} \mathrm{~cm} / \mathrm{s}\right)$ attested of the restriction of the paracellular permeability in Caco-2 cultures in the absence of compound. Caco-2 cells were trypsinized after 3 days of incubation while they cover $80-90 \%$ of the flask and seeded at a density of $5 \times 10^{5}$ in $75 \mathrm{~cm}^{2}$ flasks in complete medium supplemented with $73 \mathrm{nM}$ (around 0.04 $\mu \mathrm{g} / \mathrm{mL}$ ) of the antibacterial puromycin (3'-[ $\alpha$-Amino- $p$-methoxyhydrocinnamamido]-3'-deoxyN,N-dimethyladenosine dihydrochloride). After 5 to 6 days, Caco2 cells reach high cells density $\left(>0.5 \times 10^{5}\right.$ cells $\left./ \mathrm{cm}^{2}\right)$ and are then passage into cell HTS 24-well plates with $0.4 \mu \mathrm{m}$ Polycarbonate membrane inserts. Cells were seeded at 600000 cells $/ \mathrm{cm}^{2}$ (200 000 cells/insert) and cultivated for 6 days in complete medium with puromycin. Media was replaced every second days. Compound solutions were prepared in HEPES-buffered Ringer's (RH) solution ( $\mathrm{NaCl} 150$ $\mathrm{mM}, \mathrm{KCl} 5.2 \mathrm{mM}, \mathrm{CaCl}_{2} 2.2 \mathrm{mM}, \mathrm{MgCl}_{2} 0.2 \mathrm{mM}, \mathrm{NaHCO}_{3} 6 \mathrm{mM}$, Glucose $2.8 \mathrm{mM}$, HEPES 5 $\mathrm{mM}$, water for injection), $\mathrm{pH}=7.4$ at a final concentration of 1 to $10 \mu \mathrm{M}$ for tested drugs. For $\mathrm{A} \rightarrow \mathrm{B}$ transport experiment, $0.2 \mathrm{~mL}$ of the compound solution was placed on the apical side of the cells and samples were taken from the basolateral compartment. For $\mathrm{B} \rightarrow \mathrm{A}$ transport experiment $0.8 \mathrm{~mL}$ of the solution was placed on the basolateral side of the cells and samples were taken from apical side. Transport Studies were done in Transwell polycarbonate: HTS 24 well plate inserts (surface area: $0.33 \mathrm{~cm}^{2}-0.4 \mu \mathrm{m}$ pore size). Cells were equilibrated for 10 minutes in transport buffer prior to the transport experiment, and then incubations with compounds were performed at $37^{\circ} \mathrm{C}$ under agitation. After 1 hour aliquots were taken from each 
compartment and sampled in 96-well plates with glass insert. Permeations are calculated using the formulas below:

$$
\begin{gathered}
P_{a p p A \rightarrow B}=\frac{V_{B} \times A U C_{B(T)}}{T \times S \times A U C_{B(T 0)}} \\
P_{a p p B \rightarrow A}=\frac{V_{A} \times A U C_{A(T)}}{T \times S \times A U C_{B(T 0)}}
\end{gathered}
$$

$\mathrm{V}$ is the volume of solution in apical side (A) or basolateral side (B), AUC is the area of the LCMS/MS signal for the compound measured in A or B side at initial time (T0) or at the end of the incubation $(\mathrm{T}), \mathrm{T}$ is the incubation time and $\mathrm{S}$ is the surface area of the insert membrane.

\section{In vivo experiments}

Animals and diets. 10-12 old week male C57B16 mice were purchased from Charles River (France) and fed ad libitum with a standard diet (UAR A04, Villemoison/Orge, France). For high fat diet (HFD) experiments, 10-12 old week male C57B16 mice were fed a HFD (D12492; Research Diets; $60 \%$ kcal fat) for 8-10 weeks to induce obesity and insulin-resistance. Experiments were performed in mice with a 30\% increase in body weight. All animals were maintained in standard animal cages under conventional laboratory conditions $(12 \mathrm{~h} / 12 \mathrm{~h}$ light/dark cycle, $22^{\circ} \mathrm{C}$ ) with ad libitum access to food and water. The animals were maintained in compliance with European standards for the care and use of laboratory animals and experimental protocols approved by the local Animal Ethical Committee (agreements $\mathrm{N}^{\circ} \mathrm{CEEA}$ 07430, 01134.01 and 01134.03).

In vivo GLP-1 secretion. Mice were fasted from the time of gavage with vehicle or compound as indicated in figure legend, and gavaged with sitagliptin (25 mpk) (MSD) 45 min before blood $(250 \mu \mathrm{L})$ was sampled by retro-orbital venipuncture under isoflurane anaesthesia in EDTA- 
coated tubes containing DPP-4 inhibitors diprotin A (Sigma-Aldrich). Active GLP-1 plasma concentration was measured by ELISA (Millipore).

Gallbladder Volume Measurement. Mice either fasted or fed as indicated in figure legends, were killed by cervical dislocation. Gallbladder volume (length $\mathrm{x}$ width $\mathrm{x}$ width) was evaluated using a vernier caliper and removed to measure compound content.

Oral Glucose Tolerance Test. After an overnight fasting, mice were gavaged with Vehicle or compound and fasted for 7 hours. A bolus of glucose $(4 \mathrm{~g} / \mathrm{kg})$ was administrated by gavage and glycemia were measured at $0,15,30,60,90$ and 120 min by glucometer (Roche).

Pharmacokinetics. Compounds $\mathbf{2 2}$ and $\mathbf{2 4}$ were dissolved in distilled water $0.1 \%$ tween and administered per os at $32 \mu \mathrm{mol} / \mathrm{kg}$ to 10 -week old, male, C57B16 mice (approx. 25-30 g) (Charles River). Compound $\mathbf{2 2}$ was administered to overnight fasted animals. Three mice per time point were anesthetized with isoflurane and aliquots taken from the retro-orbital sinus using sampling heparinated tubes $\left(4{ }^{\circ} \mathrm{C}\right)$ at $10 \mathrm{~min}, 20 \mathrm{~min}, 30 \mathrm{~min}, 1 \mathrm{~h}, 2 \mathrm{~h}, 4 \mathrm{~h}$ and $8 \mathrm{~h}$ after administration of a single dose of ligands. The blood samples were centrifuged (5000 g, $15 \mathrm{~min}$ ) for plasma separation and stored at $-80^{\circ} \mathrm{C}$ before compound measurement. Plasma samples were thawed on ice. Aliquots were precipitated with ice cold acetonitrile (1 to 10 ratio) containing compound $3(0.2 \mu \mathrm{M})$ as internal standard. The samples were vigorously mixed with a vortex and centrifuged for $10 \mathrm{~min}$ at $10000 \mathrm{rpm}, 4{ }^{\circ} \mathrm{C}$, and the supernatants were transferred into Matrix tubes for LC-MS/MS analysis. Spiked standard solutions (1, 3, 10, 30, 100, 300, 1000, 3000, 10000 and $30000 \mathrm{nM}$ ) were prepared the same way. After rodent sacrifice, gallbladders, livers and intestines were removed. Gallbladders were immediately measured using a vernier caliper. Intestine was cut to isolate duodenum, jejunum, ileum and colon. All tissues were frozen in liquid nitrogen and stored at $-80^{\circ} \mathrm{C}$. Compound in tissues and in rehydrated feces (feces 
collected 24 hours after compound dosing of a dedicated group of animals) was extracted with a $\mathrm{MeOH} / \mathrm{CH}_{3} \mathrm{CN}$, 50:50 mixture (using a vortex for feces or a Tissue Lyzer II from Qiagen for tissues). After centrifugation $\left(10000 \mathrm{rpm}, 10 \mathrm{~min}, 4^{\circ} \mathrm{C}\right)$ of the homogenate samples, supernatants were diluted (1 to 10$)$ with ice acetonitrile containing compound $3(0.2 \mu \mathrm{M})$ as internal standard. After a last centrifugation, the supernatants were transferred into Matrix tubes for LC-MS/MS analysis.

Synthetic Materiels and Methods. All commercial reagents and solvents were used without further purification. Microwave-assisted chemical reactions were conducted on a CEM Discover $^{\mathrm{TM}}$ synthesis system or a Biotage $\AA$ Initiator+ microwave synthesizer. Flash column chromatography was performed on prepacked columns (Grace Resolv ${ }^{\mathrm{TM}}$ flash cartridges, Grace $^{\circledR}$ ). Preparative HPLC were performed using a Varian ProStar system using an Omnisphere 10 C18 column (250 mm x $41.4 \mathrm{~mm})$ Dynamax from Varian, Inc. or a Waters-2 system using a

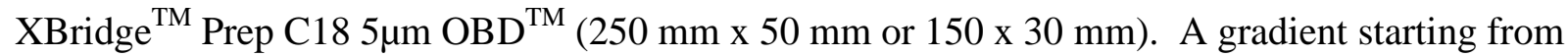
$\mathrm{CH}_{3} \mathrm{CN}-\mathrm{H}_{2} \mathrm{O}$ and formic acid (20-80-0.1\%) and reaching $100 \% \mathrm{CH}_{3} \mathrm{CN} / 0.1 \%$ formic acid at a flow rate of $80 \mathrm{~mL} /$ minutes was used on the Varian ProStar system. Products were detected by $\mathrm{UV}$ absorption at $215 \mathrm{~nm}$ and/or $254 \mathrm{~nm}$. A gradient mixture of $\mathrm{CH}_{3} \mathrm{CN}$ and water in ammonium formate buffer at $\mathrm{pH} 9.2$ or $\mathrm{pH} 3.8$ and a flow rate at 40 or $80 \mathrm{~mL} / \mathrm{min}$ was used on Waters-2 system. Products were detected by UV absorption and/or by MS. NMR spectra were recorded on a Bruker DRX-300 spectrometer. Chemical shifts are in parts per million (ppm). The assignments were made using one-dimensional (1D) ${ }^{1} \mathrm{H}$ and ${ }^{13} \mathrm{C}$ spectra and two-dimensional (2D) HSQC, HMBC and COSY spectra. LCMS analysis was performed on a Waters Alliance Micromass ZQ 2000, using an XBridge C18 column (3.5 $\mu \mathrm{m}$ particle size, dimensions $50 \mathrm{~mm}$ x $4.6 \mathrm{~mm}$ ). A mixture of water and acetonitrile was used as mobile phase in gradient-elution. $\mathrm{pH}$ of 
mobile phase was adjusted with $\mathrm{HCOOH}$ and $\mathrm{NH}_{4} \mathrm{OH}$ to form a buffer solution at $\mathrm{pH}$ 3.8. The analysis time is 5 minutes (at a flow rate at $2 \mathrm{~mL} / \mathrm{min}$ ). Purity (\%) was determined by reversed phase HPLC, using UV detection $(215 \mathrm{~nm})$, and all compound showed purity greater than $95 \%$ unless otherwise stated (17c and 26c). HRMS analysis was performed on a LCT Premier XE Micromass, using a C18 X-Bridge $3.5 \mu \mathrm{m}$ particle size column, dimensions $50 \mathrm{~mm} * 4.6 \mathrm{~mm}$. A gradient starting from $100 \% \mathrm{H}_{2} \mathrm{O} 5 \mathrm{mM}$ Ammonium Formate $\mathrm{pH}=3.8$ and reaching $100 \%$ $\mathrm{CH}_{3} \mathrm{CN} 5 \mathrm{mM}$ Ammonium Formate $\mathrm{pH}=3.8$ within $2 \mathrm{~min}$ at a flow rate of $2 \mathrm{~mL} / \mathrm{min}$ was used. Purification yields were not optimized. Final compounds were isolated as amorphous solids without collection of melting point data.

General procedure A. The 3-amino-5-thio-[1,2,4]triazolyl-amine derivative (1 eq) and the phenylboronic acid derivative (1eq) are dissolved in dichloromethane (QS $20 \mathrm{mM})$. Molecular

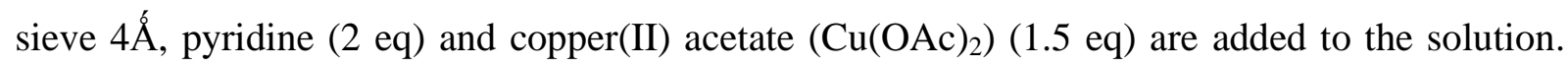
Reaction mixture is stirred at room temperature for several hours. Pyridine, phenylboronic acid derivative, and $\mathrm{Cu}(\mathrm{OAc})_{2}$ are added several time until satisfying conversion. Reaction mixture is then filtered on Celite. Filtrate is washed by water, and a saturated aqueous solution of $\mathrm{NaHCO}_{3}$. Organic phase is dried over $\mathrm{MgSO}_{4}$, and evaporated to dryness. Residue is purified by flash chromatography (DCM/MeOH).

Procedure B. In a round bottom flask is added the isothioureido-derivative (1 eq), $\mathrm{K}_{2} \mathrm{CO}_{3}$ (1 eq), sodium Iodide (0.5 eq), and acetonitrile (QS $0.2 \mathrm{M})$. The suspension is stirred at room temperature for $10 \mathrm{~min}$, benzyl halide $(1 \mathrm{eq})$ is then added. The suspension is stirred at room temperature overnight. Reaction mixture is then evaporated; residue is dissolved in EtOAc, washed with water and brine. Organic phase is dried over $\mathrm{Na}_{2} \mathrm{SO}_{4}$ and evaporated. Residue is purified by flash chromatography (cyclohexane/EtOAc). 
Procedure C. In a microwave tube are introduced the isothioureido-acetamide derivative (1 eq), EtOAc (QS 0.1M), DIEA (6 eq), and T3P® (3 eq). Reaction mixture is heated under microwave irradiation at $150^{\circ} \mathrm{C}$ for $10 \mathrm{~min}$. Reaction mixture is then diluted with EtOAc, washed by saturated aqueous solution of $\mathrm{NaHCO}_{3}$ and brine. Organic phase is then dried over $\mathrm{Na}_{2} \mathrm{SO}_{4}$ and evaporated. Residue is purified by flash chromatography (cyclohexane to cyclohexane/EtOAc).

Procedure D. In a round bottom flask are introduced the isothioureido-acetamide derivative (1 eq), EtOAc (QS 0.1M), DIEA (6 eq), and T3P® (3 eq). Reaction mixture is heated at reflux for 24h. After several hours, DIEA, and $\mathrm{T} 3 \mathrm{P} \AA$ are added several times, until completion. Reaction mixture is then diluted in EtOAc, washed by saturated aqueous solution of $\mathrm{NaHCO}_{3}$ and brine. Organic phase is dried over $\mathrm{Na}_{2} \mathrm{SO}_{4}$ and evaporated to dryness. Residue is purified by flash chromatography (cyclohexane/EtOAc).

5-Amino-4-(4-fluoro-phenyl)-4H-[1,2,4]triazole-3-thiol (1a). 4-fluorophenylisothiocyanate (1.04 g, $6.54 \mathrm{mmol})$, aminoguanidinium chloride (1.45 g, $13.1 \mathrm{mmol})$, DIEA (3.12 mL, 19.6 mmol) were dissolved in DMF $(9.40 \mathrm{~mL})$. Reaction mixture was stirred at $50^{\circ} \mathrm{C}$ for $15 \mathrm{~h}$, then evaporated to dryness. $13 \mathrm{~mL}$ of an aqueous solution of $\mathrm{NaOH} 2 \mathrm{M}$ were then added, and reaction mixture was stirred at $50{ }^{\circ} \mathrm{C}$ for 18 hours. Suspension was then filtered, and filtrate was neutralized by addition of aqueous $\mathrm{HCl} 2 \mathrm{M}$ and filtrated. Both precipitates were pulled together, to give an orange powder corresponding to the titled product $(1.2 \mathrm{~g}, 87 \%)$. MS $[\mathrm{M}+\mathrm{H}]^{+} \mathrm{m} / \mathrm{z}=$ 210.9, ${ }^{1} \mathrm{H}$ NMR (300 MHz, DMSO-d6): $\delta$ (ppm) 5.96 (s, 2H), $7.38(\mathrm{~m}, 4 \mathrm{H}), 12.80(\mathrm{~s}, 1 \mathrm{H})$.

5-(2,6-Difluoro-benzylsulfanyl)-4-(4-fluoro-phenyl)-4H-[1,2,4]triazol-3-ylamine $\quad$ (1b). 5Amino-4-(4-fluoro-phenyl)-4H-[1,2,4]triazole-3-thiol (1a) (501 mg, 2.38 mmol), 2bromomethyl-1,3-difluoro-benzene (492 mg, $2.37 \mathrm{mmol})$, DIEA (416 $\mu \mathrm{L}, 2.62 \mathrm{mmol})$ were dissolved in $12 \mathrm{~mL}$ of dichloromethane. Reaction mixture was stirred at room temperature for 3 
hours, then washed with water and brine, and organic phase was dried over $\mathrm{MgSO}_{4}$, and evaporated to dryness to give $787 \mathrm{mg}$ of the expected product as a white powder (98\%). MS $[\mathrm{M}+\mathrm{H}]^{+} m / z=336.9,{ }^{1} \mathrm{H}$ NMR $(300 \mathrm{MHz}, \mathrm{DMSO}-d 6): \delta(\mathrm{ppm}) 3.88(\mathrm{~s}, 2 \mathrm{H}), 5.89(\mathrm{~s}, 2 \mathrm{H}), 7.03$ $(\mathrm{t}, J=8.0 \mathrm{~Hz}, 2 \mathrm{H}), 7.26-7.40(\mathrm{~m}, 5 \mathrm{H})$.

$N$-[5-(2,6-Difluoro-benzylsulfanyl)-4-(4-fluoro-phenyl)-4H-[1,2,4]triazol-3-yl]-acetamide (1c). 5-(2,6-Difluoro-benzylsulfanyl)-4-(4-fluoro-phenyl)-4H-[1,2,4]triazol-3-ylamine (1b) (318 $\mathrm{mg}, 94.5 \mu \mathrm{mol})$ was dissolved in $0.5 \mathrm{~mL}$ of dichloromethane and acetic anhydride $(450 \mu \mathrm{L}, 4.73$ mmol) was then added. Reaction mixture was stirred at room temperature for $30 \mathrm{~min} .5 \mathrm{~mL}$ of an aqueous solution of $\mathrm{NaHCO}_{3} 2 \mathrm{~N}$ were then added. Phases were separated, and organic phase was dried over $\mathrm{MgSO}_{4}$, and evaporated to dryness. Residue was recrystallized in isopropanol to give the titled product as white crystals $(238 \mathrm{mg}, 66 \%)$. MS $[\mathrm{M}+\mathrm{H}]^{+} \mathrm{m} / z=378.9,{ }^{1} \mathrm{H}$ NMR $(300$ MHz, DMSO-d6): $\delta(\mathrm{ppm}) 1.84(\mathrm{~s}, 3 \mathrm{H}), 4.19(\mathrm{~s}, 2 \mathrm{H}), 7.05(\mathrm{t}, J=8.0 \mathrm{~Hz}, 2 \mathrm{H}), 7.23-7.42(\mathrm{~m}, 5 \mathrm{H})$, 10.37 (brs, $1 \mathrm{H})$.

\section{$N$-[5-(2,6-Difluoro-benzylsulfanyl)-4-(4-fluoro-phenyl)-4H-[1,2,4]triazol-3-yl]- $N$-(3,4-}

dimethoxy-phenyl)-acetamide (1d). The titled compound was obtained as a yellowish oil (420 mg, $50 \%)$ following procedure A, using N-[5-(2,6-Difluoro-benzylsulfanyl)-4-(4-fluorophenyl)-4H-[1,2,4]triazol-3-yl]-acetamide $\quad(\mathbf{1 c}) \quad(570 \quad \mathrm{mg}, \quad 1.5 \quad \mathrm{mmol}), \quad$ and $3,4-$ dimethoxyphenylboronic acid. MS $[\mathrm{M}+\mathrm{H}]^{+} \mathrm{m} / z=514.9,{ }^{1} \mathrm{H}$ NMR (300 MHz, DMSO- $\left.d 6\right)$ : $\delta$ (ppm) $1.65(\mathrm{~s}, 3 \mathrm{H}), 3.79(\mathrm{~s}, 3 \mathrm{H}), 3.81(\mathrm{~s}, 3 \mathrm{H}), 4.31(\mathrm{~s}, 2 \mathrm{H}), 7.05-7.18(\mathrm{~m}, 3 \mathrm{H})$, 7.24-7.54 (m, $7 \mathrm{H})$.

[5-(2,6-Difluoro-benzylsulfanyl)-4-(4-fluoro-phenyl)-4H-[1,2,4]triazol-3-yl]-(3,4-dimethoxyphenyl)-amine (1). Acetyl chloride $(2.4 \mathrm{~mL})$ and ethanol $(5 \mathrm{~mL})$ were gently mixed at $0-5^{\circ} \mathrm{C}$, and the mixture was added to a solution of N-[5-(2,6-Difluoro-benzylsulfanyl)-4-(4-fluoro- 
phenyl)-4H-[1,2,4]triazol-3-yl]-N-(3,4-dimethoxy-phenyl)-acetamide (1d) $(310 \mathrm{mg}, 602 \mu \mathrm{mol})$ in $4.6 \mathrm{~mL}$ of ethanol. Reaction mixture was then heated at $100^{\circ} \mathrm{C}$ for $30 \mathrm{~min}$. Reaction mixture was then evaporated. The residue was dissolved in EtOAc, washed with water, and with a saturated aqueous solution of $\mathrm{NaHCO}_{3}$. Organic phase was dried over $\mathrm{MgSO}_{4}$, and evaporated to dryness. Residue was recrystallized in a mixture of isopropanol/methanol to give $163.5 \mathrm{mg}$ of the expected product as a white solid (57\%). LC-MS: $\mathrm{t}_{\mathrm{R}}=2.60 \mathrm{~min}, \mathrm{MS}[\mathrm{M}+\mathrm{H}]^{+} \mathrm{m} / z=472.9,{ }^{1} \mathrm{H}$ NMR (300 MHz, DMSO-d6): $\delta(\mathrm{ppm}) 3.77$ (s, 3H, O- $\left.\mathrm{CH}_{3}\right), 3.78$ (s, 3H, O- $\left.\underline{\mathrm{CH}}_{3}\right), 4.22$ (s, 2H, S-

$\left.\underline{\mathrm{CH}}_{2}\right), 5.13$ (brs, $\left.1 \mathrm{H}, \mathrm{NH}\right), 7.00(\mathrm{~d}, J=8.8 \mathrm{~Hz}, 2 \mathrm{H}, \mathrm{Ar}), 7.35-7.55$ (m, 8H, Ar). ${ }^{13} \mathrm{C}$ NMR $(75$ MHz, DMSO- $d 6): \delta(\mathrm{ppm}) 24.0,56.0,56.2,110.9,112.0,112.3,113.1(\mathrm{t}, J=18.9 \mathrm{~Hz}), 117.5(\mathrm{~d}$, $J=23.2 \mathrm{~Hz}), 126.6-129.3(\mathrm{~m}), 130.9(\mathrm{t}, J=10.4 \mathrm{~Hz}), 131.3(\mathrm{~d}, J=8.9 \mathrm{~Hz}), 132.4-133.0(\mathrm{~m})$, 142.2, 146.1, 149.2, 151.9, 160.9, $161.1(\mathrm{dd}, J=248.4,7.2 \mathrm{~Hz}), 162.7(\mathrm{~d}, J=247.9 \mathrm{~Hz})$.

\section{[5-(2,6-Difluoro-benzylsulfanyl)-4-(4-fluoro-phenyl)-4H-[1,2,4]triazol-3-yl]-methyl-amine}

(2c). A suspension of 5-(2,6-Difluoro-benzylsulfanyl)-4-(4-fluoro-phenyl)-4H-[1,2,4]triazol-3ylamine (1b) (200 mg, $595 \mu \mathrm{mol})$ and sodium methanolate $(161 \mathrm{mg}, 2.98 \mathrm{mmol})$ in methanol (QS $0.5 \mathrm{M})$ was added to paraformaldehyde $(25 \mathrm{mg}, 833 \mu \mathrm{mol})$. Reaction mixture was stirred at room temperature for 16 hours. $\mathrm{NaBH}_{4}(22.5 \mathrm{mg}, 595 \mu \mathrm{mol})$ was then added, and reaction mixture was stirred at reflux for $30 \mathrm{~min}$. After cooling down to room temperature, reaction mixture was partially evaporated. Aqueous $\mathrm{KOH} 1 \mathrm{M}$ was then added. This solution was then extracted by EtOAc. Organic phase was dried over $\mathrm{MgSO}_{4}$, and evaporated to dryness. Residue was purified by flash chromatography using as eluent a mixture of $\mathrm{DCM} / \mathrm{MeOH}$ to give the titled compound as a yellowish solid $(157 \mathrm{mg}, 76 \%)$. MS $[\mathrm{M}+\mathrm{H}]^{+} \mathrm{m} / z=350.9,{ }^{1} \mathrm{H} \mathrm{NMR}(300 \mathrm{MHz}$, DMSO-d6): $\delta$ (ppm) $2.73(\mathrm{~d}, J=4.8 \mathrm{~Hz}, 3 \mathrm{H}), 3.91(\mathrm{~s}, 2 \mathrm{H}), 5.82(\mathrm{q}, J=4.7 \mathrm{~Hz}, 1 \mathrm{H}), 7.04(\mathrm{t}, J=$ $8.0 \mathrm{~Hz}, 2 \mathrm{H}), 7.25-7.43(\mathrm{~m}, 5 \mathrm{H})$. 
[5-(2,6-Difluoro-benzylsulfanyl)-4-(4-fluoro-phenyl)-4H-[1,2,4]triazol-3-yl]-(3,4-dimethoxyphenyl)-methyl-amine (2). The titled compound was obtained as a yellowish solid (42.4 mg, $11 \%)$ after purification by preparative HPLC, following procedure A using [[5-(2,6-Difluorobenzylsulfanyl)-4-(4-fluoro-phenyl)-4H-[1,2,4]triazol-3-yl]-methyl-amine $(\mathbf{2 c}) \quad(281 \mathrm{mg}, 800$ $\mu \mathrm{mol}$ ) and 3,4-dimethoxyphenylboronic acid. LC-MS: $\mathrm{t}_{\mathrm{R}}=2.60 \mathrm{~min}, \mathrm{MS}[\mathrm{M}+\mathrm{H}]^{+} \mathrm{m} / z=486.9$. HRMS found 487.1394; $\mathrm{C}_{24} \mathrm{H}_{21} \mathrm{~F}_{3} \mathrm{~N}_{4} \mathrm{O}_{2} \mathrm{~S}$ requires 487.1416. ${ }^{1} \mathrm{H}$ NMR (300 $\mathrm{MHz}, \mathrm{CDCl}_{3}$ ): $\delta$ (ppm) $2.69(\mathrm{~s}, 3 \mathrm{H}), 3.92(\mathrm{~s}, 3 \mathrm{H}), 3.95(\mathrm{~s}, 3 \mathrm{H}), 4.26(\mathrm{~s}, 2 \mathrm{H}), 6.84-6.94(\mathrm{~m}, 3 \mathrm{H})$, 7.10-7.42 (m, $7 \mathrm{H})$.

(3,4-dimethoxy-phenyl)-methyl-amine (3a). In a $250 \mathrm{~mL}$ flask were added $3 \mathrm{~g}$ of 3,4dimethoxyaniline and $5.29 \mathrm{~g}$ of sodium methoxide in $35 \mathrm{~mL}$ of methanol (dried over $\mathrm{Na}_{2} \mathrm{SO}_{4}$ ). Then, $1.18 \mathrm{~g}$ of paraformaldehyde and $15 \mathrm{~mL}$ of methanol (dried over $\mathrm{Na}_{2} \mathrm{SO}_{4}$ ) were added. Molecular sieve (4 $\AA$ ) was then added and the mixture was stirred overnight at room temperature. $0.74 \mathrm{~g}$ of sodium borohydride were then added, and the mixture was heated under reflux for 1 hour. The mixture was then evaporated, dissolved in EtOAc and water, the two phases were separated. The aqueous phase was then basified by addition of a saturated aqueous solution of $\mathrm{NaHCO}_{3}$, and extracted by EtOAc. The organic phases were washed with a saturated aqueous solution of $\mathrm{NaHCO}_{3}$, brine, dried over $\mathrm{Na}_{2} \mathrm{SO}_{4}$ and evaporated to dryness to give the titled product as an oily residue $(2.67 \mathrm{~g}, 77 \%)$, which was used without further purification in the next step of the synthesis. MS $[\mathrm{M}+\mathrm{H}]^{+} \mathrm{m} / z=168.0 .{ }^{1} \mathrm{H}$ NMR $(300 \mathrm{MHz}, \mathrm{DMSO}-d 6): \delta$ (ppm) $2.62(\mathrm{~d}, J=5.0 \mathrm{~Hz}, 3 \mathrm{H}), 3.61(\mathrm{~s}, 3 \mathrm{H}), 3.69(\mathrm{~s}, 3 \mathrm{H}), 5.20(\mathrm{q}, J=4.9 \mathrm{~Hz}, 1 \mathrm{H}), 5.99(\mathrm{dd}, J=$ $8.5,2.5 \mathrm{~Hz}, 1 \mathrm{H}), 6.22,(\mathrm{~d}, J=2.5 \mathrm{~Hz}, 1 \mathrm{H}), 6.71(\mathrm{~d}, J=8.5 \mathrm{~Hz}, 1 \mathrm{H})$.

2-Chloro-N-(3,4-dimethoxy-phenyl)-N-methyl-acetamide (3b). In a $250 \mathrm{~mL}$ flask were introduced a solution of $2.67 \mathrm{~g}$ of (3,4-dimethoxy-phenyl)-methyl-amine (3a) and $7.9 \mathrm{~mL}$ of 
DIEA in $45 \mathrm{~mL}$ of DCM (dried over $\mathrm{Na}_{2} \mathrm{SO}_{4}$ ). The solution was stirred at $0^{\circ} \mathrm{C}$. Then, a solution of $2.4 \mathrm{~mL}$ of chloroacetyl chloride in $30 \mathrm{~mL}$ of $\mathrm{DCM}$ (dried over $\mathrm{Na}_{2} \mathrm{SO}_{4}$ ) was added dropwise in the flask. The mixture was then evaporated to dryness to give a brown residue which was used without further purification in the next step of the synthesis. MS $[\mathrm{M}+\mathrm{H}]^{+} m / z=244.1$.

[2-(3,4-Dimethoxy-N-methyl-anilino)-2-oxo-ethyl]ammonium formate (3c). Residue corresponding to 2-Chloro-N-(3,4-dimethoxy-phenyl)-N-methyl-acetamide (3b) obtained was dissolved in $25 \mathrm{~mL}$ of Ethanol $95^{\circ}$, and added dropwise in a $500 \mathrm{~mL}$ flask containing $320 \mathrm{~mL}$ of aqueous ammonia at $65^{\circ} \mathrm{C}$. Reaction mixture was then evaporated to dryness. Residue was dissolved in DCM, and extracted several times with an aqueous solution of $\mathrm{HCOOH} 1 \mathrm{M}$. Aqueous phase was then evaporated to dryness, and the residue was triturated in acetonitrile. The supernatant was evaporated to dryness, to give the titled product as a brown powder $(3.82 \mathrm{~g}, 75$ $\%$ yield over the 2 steps). MS $[\mathrm{M}+\mathrm{H}]^{+} \mathrm{m} / z=225.1 .{ }^{1} \mathrm{H}$ NMR (300 MHz, DMSO- $\left.d 6\right): \delta(\mathrm{ppm})$ $3.17(\mathrm{~s}, 3 \mathrm{H}), 3.76-3.77(\mathrm{~m}, 6 \mathrm{H}), 3.99(\mathrm{~s}, 2 \mathrm{H}), 6.90(\mathrm{dd}, J=8.4,2.2 \mathrm{~Hz}, 1 \mathrm{H}), 6.99-7.03(\mathrm{~m}, 2 \mathrm{H})$, 8.00 (brs, 3H), $8.20(\mathrm{~s}, 1 \mathrm{H})$.

N-(3,4-Dimethoxy-phenyl)-2-[3-(4-fluoro-phenyl)-isothioureido]-N-methyl-acetamide (3d). $1.5 \mathrm{~g}$ of 4-fluorophenylisothiocyanate and $1.59 \mathrm{~mL}$ of TEA were added in a $250 \mathrm{~mL}$ flask in 15 $\mathrm{mL}$ of ethanol. $3.2 \mathrm{~g}$ of [2-(3,4-dimethoxy-N-methyl-anilino)-2-oxo-ethyl]ammonium formate (3c) were dissolved in $115 \mathrm{~mL}$ of ethanol, $1.33 \mathrm{~mL}$ of TEA were added, and the mixture was added dropwise at room temperature. After the addition, the reaction was over. Reaction mixture was evaporated to dryness and purified by flash chromatography using as eluent a mixture of cyclohexane/EtOAc to give the titled product as a yellowish powder $(2.8 \mathrm{~g}, 76 \%)$. MS $[\mathrm{M}-\mathrm{H}]^{-}$ $m / z=244.1 .{ }^{1} \mathrm{H}$ NMR $(300 \mathrm{MHz}, \mathrm{DMSO}-d 6): \delta(\mathrm{ppm}) 2.49(\mathrm{~s}, 3 \mathrm{H}), 3.78(\mathrm{~m}, 6 \mathrm{H}), 4.00(\mathrm{~d}, J=$ 
$4.1 \mathrm{~Hz}, 2 \mathrm{H}), 6.92(\mathrm{dd}, J=8.4,1.8 \mathrm{~Hz}, 1 \mathrm{H}), 7.01-7.03(\mathrm{~m}, 2 \mathrm{H}), 7.15(\mathrm{~m}, 2 \mathrm{H}), 7.45(\mathrm{~m}, 2 \mathrm{H}), 7.73$ (m, 1H), $9.90(\mathrm{~s}, 1 \mathrm{H})$.

2-[2-(2,6-Difluoro-benzyl)-3-(4-fluoro-phenyl)-isothioureido]-N-(3,4-dimethoxy-phenyl)-Nmethyl-acetamide (3e) The titled product was obtained without purification as an oily residue (1.15 g, 91\%), following Procedure B, using N-(3,4-Dimethoxy-phenyl)-2-[3-(4-fluoro-phenyl)isothioureido]-N-methyl-acetamide (3d) $(940 \mathrm{mg}$ ) and 2-Bromomethyl-1,3-difluoro-benzene (518 mg). MS $[\mathrm{M}+\mathrm{H}]^{+} \mathrm{m} / z=504.0 .{ }^{1} \mathrm{H}$ NMR (300 MHz, DMSO-d6): $\delta(\mathrm{ppm}) 3.16$ (s, 3H), 3.69$3.76(\mathrm{~m}, 8 \mathrm{H}), 4.19(\mathrm{~s}, 2 \mathrm{H}), 6.61(\mathrm{~m}, 2 \mathrm{H}), 6.79-6.89(\mathrm{~m}, 2 \mathrm{H}), 6.95-7.00(\mathrm{~m}, 4 \mathrm{H}), 7.05-7.13(\mathrm{~m}$, 3H), $7.38(\mathrm{~m}, 1 \mathrm{H})$.

\section{[2-(2,6-Difluoro-benzylsulfanyl)-3-(4-fluoro-phenyl)-3H-imidazol-4-yl]-(3,4-dimethoxy-}

phenyl)-methyl-amine (3). In a $50 \mathrm{~mL}$ flask were added 2-[2-(2,6-difluoro-benzyl)-3-(4-fluorophenyl)-isothioureido]-N-(3,4-dimethoxy-phenyl)-N-methyl-acetamide (3e) (500 mg), $10 \mathrm{~mL}$ EtOAc, $\mathrm{NEt}_{3}(843 \mu \mathrm{L})$, and $\mathrm{T} 3 \mathrm{P} \circledast(1.77 \mathrm{~mL})$. Reaction mixture was then stirred at reflux for 28 hours. After 8 hours, $\mathrm{NEt}_{3}(843 \mu \mathrm{L})$ and T3P® $(1.77 \mathrm{~mL})$ were added. After 25 hours, $\mathrm{NEt}_{3}(422$ $\mu \mathrm{L})$ and $\mathrm{T} 3 \mathrm{P} \circledast(885 \mu \mathrm{L})$ were added. After dilution with $20 \mathrm{~mL}$ EtOAc, the solution was washed with a saturated aqueous solution of $\mathrm{NaHCO}_{3}$, and brine. Organic phase was dried over $\mathrm{Na}_{2} \mathrm{SO}_{4}$ and evaporated. Residue was purified by flash chromatography using as eluent a mixture of $\mathrm{DCM} / \mathrm{MeOH}$. The titled product was obtained as an oily residue $(160 \mathrm{mg}, 33 \%)$. LC-MS: $\mathrm{t}_{\mathrm{R}}=$ 3.13 min, MS $[\mathrm{M}+\mathrm{H}]^{+} \mathrm{m} / z=486.3$. HRMS found 486.1437; $\mathrm{C}_{25} \mathrm{H}_{22} \mathrm{~F}_{3} \mathrm{~N}_{3} \mathrm{O}_{2} \mathrm{~S}$ requires 486.1463. ${ }^{1} \mathrm{H}$ NMR $\left(300 \mathrm{MHz}, \mathrm{CDCl}_{3}\right.$ ): $\delta(\mathrm{ppm}) 2.92$ (s, 3H),3.80 (s, 3H), 3.82 (s, 3H), 4.16 (s, 2H), 6.16 $(\mathrm{dd}, J=8.7,2.7 \mathrm{~Hz}, 1 \mathrm{H}), 6.30(\mathrm{~d}, J=2.7 \mathrm{~Hz}, 1 \mathrm{H}), 6.72(\mathrm{~d}, J=8.7 \mathrm{~Hz}, 1 \mathrm{H}), 6.78(\mathrm{~m}, 2 \mathrm{H}), 6.83-$ $6.85(\mathrm{~m}, 4 \mathrm{H}), 6.92(\mathrm{~s}, 1 \mathrm{H}), 7.19(\mathrm{~m}, 1 \mathrm{H}) .{ }^{13} \mathrm{C} \mathrm{NMR}\left(75 \mathrm{MHz}, \mathrm{CDCl}_{3}\right): \delta(\mathrm{ppm}) 25.9,40.1,55.9$, 56.4, 99.9, 105.5, 111.2, 112.4, 113.6 (t, $J=19.3 \mathrm{~Hz}), 115.9(\mathrm{~d}, J=22.9 \mathrm{~Hz}), 124.4,129.1$, 
$129.2,130.8,138.1,139.6,142.7,143.2,149.6,161.1(\mathrm{dd}, J=250.0,7.7 \mathrm{~Hz}), 162.2(\mathrm{~d}, J=249.0$ $\mathrm{Hz})$.

\section{N-(3,4-Dimethoxy-phenyl)-2-[2-(2-fluoro-benzyl)-3-(4-fluoro-phenyl)-isothioureido]-N-}

methyl-acetamide (4e). The titled product was obtained without purification as an oily residue (254 mg, 96\%), following Procedure B, using N-(3,4-Dimethoxy-phenyl)-2-[3-(4-fluorophenyl)-isothioureido]-N-methyl-acetamide (3d) (195 mg) and 1-(bromomethyl)-2-fluorobenzene $(94 \mathrm{mg})$. MS $[\mathrm{M}+\mathrm{H}]^{+} \mathrm{m} / z=486.0,{ }^{1} \mathrm{H}$ NMR $\left(300 \mathrm{MHz}, \mathrm{DMSO}-d_{6}\right): \delta(\mathrm{ppm}) 3.16(\mathrm{~s}$, 3H), 3.39-3.76 (m, 8H), $4.17(\mathrm{~s}, 2 \mathrm{H}), 6.59-6.89(\mathrm{~m}, 4 \mathrm{H}), 6.95-7.00(\mathrm{~m}, 4 \mathrm{H}), 7.11-7.19(\mathrm{~m}, 2 \mathrm{H})$, $7.31(\mathrm{~m}, 1 \mathrm{H}), 7.41(\mathrm{~m}, 1 \mathrm{H})$

(3,4-Dimethoxy-phenyl)-[2-(2-fluoro-benzylsulfanyl)-3-(4-fluoro-phenyl)-3H-imidazol-4-yl]methyl-amine (4). The titled product was obtained as an orange powder (130 $\mathrm{mg}, 61 \%)$, following Procedure C, using N-(3,4-Dimethoxy-phenyl)-2-[2-(2-fluoro-benzyl)-3-(4-fluorophenyl)-isothioureido]-N-methyl-acetamide (4e). LC-MS: $\mathrm{t}_{\mathrm{R}}=3.28 \mathrm{~min}, \mathrm{MS}[\mathrm{M}+\mathrm{H}]^{+} \mathrm{m} / \mathrm{z}=$ 468.0. HRMS found 468.1544; $\mathrm{C}_{25} \mathrm{H}_{23} \mathrm{~F}_{2} \mathrm{~N}_{3} \mathrm{O}_{2} \mathrm{~S}$ requires 468.1557. ${ }^{1} \mathrm{H}$ NMR (300 MHz, $\mathrm{CDCl}_{3}$ ): $\delta(\mathrm{ppm}) 3.77(\mathrm{~s}, 3 \mathrm{H}), 3.81(\mathrm{~s}, 3 \mathrm{H}), 4.27(\mathrm{~s}, 2 \mathrm{H}), 6.11(\mathrm{dd}, J=8.7,2.7 \mathrm{~Hz}, 1 \mathrm{H}), 6.22(\mathrm{~d}, J=2.7$ $\mathrm{Hz}, 1 \mathrm{H}), 6.69(\mathrm{~d}, J=8.7 \mathrm{~Hz}, 1 \mathrm{H}), 6.79-6.84(\mathrm{~m}, 2 \mathrm{H}), 6.90-7.06(\mathrm{~m}, 5 \mathrm{H}), 7.20-7.25(\mathrm{~m}, 2 \mathrm{H}) .{ }^{13} \mathrm{C}$ NMR (75 MHz, $\left.\mathrm{CDCl}_{3}\right): \delta(\mathrm{ppm}) 31.8,40.3,55.9,56.5,100.0,105.8,112.4,115.5(\mathrm{~d}, J=21.5$ Hz), $116.0(\mathrm{~d}, J=22.8 \mathrm{~Hz}), 123.8,124.1,124.7(\mathrm{~d}, J=14.8 \mathrm{~Hz}), 129.1,129.2,129.4,130.7$, 131.0, 139.1, 139.3, 142.7, 143.1, 149.6, $160.9(\mathrm{~d}, J=248.3 \mathrm{~Hz}), 162.4(\mathrm{~d}, J=249.8 \mathrm{~Hz})$.

\section{2-[2-Benzyl-3-(4-fluoro-phenyl)-isothioureido]-N-(3,4-dimethoxy-phenyl)-N-methyl-}

acetamide (5e). The titled product was obtained without purification as an oily residue (259 $\mathrm{mg}$, 98\%), following Procedure B, using N-(3,4-Dimethoxy-phenyl)-2-[3-(4-fluoro-phenyl)isothioureido]-N-methyl-acetamide (3d) $(195 \mathrm{mg} \text { ) and benzylbromide (85 mg). MS [M+H] }]^{+} \mathrm{m} / \mathrm{z}$ 
$=468.0,{ }^{1} \mathrm{H}$ NMR $\left(300 \mathrm{MHz}, \mathrm{DMSO}-d_{6}\right): \delta(\mathrm{ppm}) 3.17(\mathrm{~s}, 3 \mathrm{H}), 3.69-3.76(\mathrm{~m}, 8 \mathrm{H}), 4.14(\mathrm{~s}, 2 \mathrm{H})$, $6.61(\mathrm{~m}, 3 \mathrm{H}), 6.88(\mathrm{~m}, 1 \mathrm{H}), 6.95-7.01(\mathrm{~m}, 4 \mathrm{H})$, 7.22-7.31 (m, 5H).

\section{[2-Benzylsulfanyl-3-(4-fluoro-phenyl)-3H-imidazol-4-yl]-(3,4-dimethoxy-phenyl)-methyl-}

amine (5). The titled product was obtained as an orange powder $(68 \mathrm{mg}, 32 \%)$, following Procedure C, using 2-[2-Benzyl-3-(4-fluoro-phenyl)-isothioureido]-N-(3,4-dimethoxy-phenyl)$\mathrm{N}$-methyl-acetamide (5e) (249 mg). LC-MS: $\mathrm{t}_{\mathrm{R}}=3.32 \mathrm{~min}, \mathrm{MS}[\mathrm{M}+\mathrm{H}]^{+} \mathrm{m} / z=450.0 . \mathrm{HRMS}$ found 450.1659; $\mathrm{C}_{25} \mathrm{H}_{24} \mathrm{FN}_{3} \mathrm{O}_{2} \mathrm{~S}$ requires 450.1652. ${ }^{1} \mathrm{H} \mathrm{NMR}\left(\mathrm{CDCl}_{3}\right): \delta(\mathrm{ppm}) 2.92(\mathrm{~s}, 3 \mathrm{H}), 3.75$ (s, 3H), $3.81(\mathrm{~s}, 3 \mathrm{H}), 4.26(\mathrm{~s}, 2 \mathrm{H}), 6.09(\mathrm{dd}, J=8.8,2.8 \mathrm{~Hz}, 1 \mathrm{H}), 6.20(\mathrm{~d}, J=2.7 \mathrm{~Hz}, 1 \mathrm{H}), 6.68$ $(\mathrm{d}, J=8.8 \mathrm{~Hz}, 1 \mathrm{H}), 6.74-6.78(\mathrm{~m}, 2 \mathrm{H}), 6.89-6.95(\mathrm{~m}, 2 \mathrm{H}), 7.04(\mathrm{~s}, 1 \mathrm{H}), 7.19-7.29(\mathrm{~m}, 5 \mathrm{H}) .{ }^{13} \mathrm{C}$ NMR (75 MHz, $\left.\mathrm{CDCl}_{3}\right): \delta(\mathrm{ppm}) 38.7,40.3,55.9,56.5,99.9,105.8,112.4,115.7,115.9(\mathrm{~d}, J=$ $22.8 \mathrm{~Hz}), 123.6,127.4,128.5,129.0,129.3$ (d, $J=8.6 \mathrm{~Hz}), 130.7,137.4,139.2,139.4,142.7$, $143.1,149.5,162.4(\mathrm{~d}, J=248.9 \mathrm{~Hz})$.

N-(3,4-Dimethoxy-phenyl)-2-[2-(2,6-dimethyl-benzyl)-3-(4-fluoro-phenyl)-isothioureido]-Nmethyl-acetamide (6e). The titled product was obtained without purification as an oily residue (230 mg, 90\%), following Procedure B, using N-(3,4-Dimethoxy-phenyl)-2-[3-(4-fluorophenyl)-isothioureido]-N-methyl-acetamide (3d) (195 mg) and 2-(chloromethyl)-1,3-dimethylbenzene $(77 \mathrm{mg})$. MS $[\mathrm{M}+\mathrm{H}]^{+} \mathrm{m} / z=496.0,{ }^{1} \mathrm{H}$ NMR (300 MHz, DMSO- $\left.d_{6}\right): \delta(\mathrm{ppm}) 2.25(\mathrm{~s}$, $6 \mathrm{H}), 3.18(\mathrm{~s}, 3 \mathrm{H}), 3.68-3.77(\mathrm{~m}, 8 \mathrm{H}), 4.14(\mathrm{~s}, 2 \mathrm{H}), 6.69-7.05(\mathrm{~m}, 11 \mathrm{H})$.

\section{(3,4-Dimethoxy-phenyl)-[2-(2,6-dimethyl-benzylsulfanyl)-3-(4-fluoro-phenyl)-3H-imidazol-}

4-yl]-methyl-amine (6). The titled product was obtained as an orange powder (63 $\mathrm{mg}, 34 \%)$ following procedure C using N-(3,4-Dimethoxy-phenyl)-2-[2-(2,6-dimethyl-benzyl)-3-(4-fluorophenyl)-isothioureido]-N-methyl-acetamide (6e) $(200 \mathrm{mg}) . \mathrm{LC}-\mathrm{MS}: \mathrm{t}_{\mathrm{R}}=3.45 \mathrm{~min}, \mathrm{MS}[\mathrm{M}+\mathrm{H}]^{+}$ $m / z=478.0$. HRMS found 478.1974; $\mathrm{C}_{27} \mathrm{H}_{28} \mathrm{FN}_{3} \mathrm{O}_{2} \mathrm{~S}$ requires 478.1965. ${ }^{1} \mathrm{H}$ NMR $(300 \mathrm{MHz}$, 
$\left.\mathrm{CDCl}_{3}\right): \delta(\mathrm{ppm}) 2.28(\mathrm{~s}, 6 \mathrm{H}), 2.95(\mathrm{~s}, 3 \mathrm{H}), 3.78(\mathrm{~s}, 3 \mathrm{H}), 3.82(\mathrm{~s}, 3 \mathrm{H}), 4.34(\mathrm{~s}, 2 \mathrm{H}), 6.15(\mathrm{dd}, J=$ 8.7, 2.7 Hz, 1H), $6.25(\mathrm{~d}, J=2.8 \mathrm{~Hz}, 1 \mathrm{H}), 6.70(\mathrm{~d}, J=8.7 \mathrm{~Hz}, 1 \mathrm{H}), 6.86-7.05(\mathrm{~m}, 8 \mathrm{H}) .{ }^{13} \mathrm{C} \mathrm{NMR}$ $\left(75 \mathrm{MHz}, \mathrm{CDCl}_{3}\right): \delta(\mathrm{ppm}) 19.6,33.3,40.4,56.0,56.4,100.1,106.1,112.4,115.9(\mathrm{~d}, J=23.0$ $\mathrm{Hz}), 123.4,127.5,128.3,129.3(\mathrm{~d}, J=8.7 \mathrm{~Hz}), 130.8,132.4,137.6,139.4,140.0,142.8,143.1$, $149.6,162.3(\mathrm{~d}, J=250.2 \mathrm{~Hz})$.

\section{N-(3,4-Dimethoxy-phenyl)-N-methyl-2-(3-phenyl-isothioureido)-acetamide}

Phenylisothiocyanate $(159.5 \mu \mathrm{L}, 1.33 \mathrm{mmol})$ and $\mathrm{NEt}_{3}(216 \mu \mathrm{L}, 1.60 \mathrm{mmol})$ were added in a 100 $\mathrm{mL}$ flask in $2 \mathrm{~mL}$ of ethanol. Residue from [2-(3,4-dimethoxy-N-methyl-anilino)-2-oxoethyl]ammonium formate $(3 \mathrm{c})(400 \mathrm{mg}, 1.33 \mathrm{mmol})$ was dissolved in $16 \mathrm{~mL}$ of ethanol, $\mathrm{NEt}_{3}$ $(180 \mu \mathrm{L}, 1.33 \mathrm{mmol})$ was added, and the mixture was added dropwise at room temperature. After the addition, the reaction was over. Reaction mixture was evaporated to dryness, and purified by flash chromatography using as eluent a mixture of $\mathrm{DCM} / \mathrm{MeOH}(99.5 / 0.5)$ to give the titled product as a yellowish residue $(162 \mathrm{mg}, 34 \%)$. MS $[\mathrm{M}+\mathrm{H}]^{+} \mathrm{m} / z=359.9$.

\section{2-[2-(2,6-Difluoro-benzyl)-3-phenyl-isothioureido]-N-(3,4-dimethoxy-phenyl)-N-methyl-}

acetamide (7e). The titled product was obtained as yellowish solid (183 mg, 84\%), without purification, following Procedure B, using $N$-(3,4-Dimethoxy-phenyl)-N-methyl-2-(3-phenylisothioureido)-acetamide (7d) $(162 \mathrm{mg}, 450 \mu \mathrm{mol})$ and 2-Bromomethyl-1,3-difluoro-benzene (93 $\mathrm{mg}, 450 \mu \mathrm{mol}) . \mathrm{MS}[\mathrm{M}+\mathrm{H}]^{+} \mathrm{m} / z=486.0,{ }^{1} \mathrm{H} \mathrm{NMR}\left(300 \mathrm{MHz}, \mathrm{CDCl}_{3}\right): \delta(\mathrm{ppm}) 3.27(\mathrm{~s}, 3 \mathrm{H})$, 3.81-3.87 (m, 8H),4.12 (s, 2H), 6.68-7.21 (m, 11H).

\section{[2-(2,6-Difluoro-benzylsulfanyl)-3-phenyl-3H-imidazol-4-yl]-(3,4-dimethoxy-phenyl)-}

methyl-amine (7). 2-[2-(2,6-Difluoro-benzyl)-3-phenyl-isothioureido]-N-(3,4-dimethoxyphenyl)-N-methyl-acetamide (7e) $(183 \mathrm{mg}, 0.38 \mathrm{mmol})$ was dissolved in $3.8 \mathrm{~mL}$ of EtOAc. DIEA $(395 \mu \mathrm{L}, 2.26 \mathrm{mmol})$, and T3P® in EtOAc $(666 \mu \mathrm{L}, 1.13 \mathrm{mmol})$ were then added. The 
reaction mixture was heated under microwave irradiation at $150^{\circ} \mathrm{C}$ for $10 \mathrm{~min}$. Reaction mixture was then diluted with EtOAc, washed with a saturated aqueous solution of $\mathrm{NaHCO}_{3}$, and brine. Organic phase was then dried over $\mathrm{Na}_{2} \mathrm{SO}_{4}$ and evaporated to dryness. Residue was then purified by flash chromatography using as eluent a mixture of cyclohexane/EtOAc (85/15), and then again by flash chromatography using as eluent a mixture of cyclohexane/DCM (1/1) to DCM/ $\mathrm{MeOH}(99 / 1)$ to give the titled product as a reddish solid $(21 \mathrm{mg}, 11 \%) . \mathrm{LC}-\mathrm{MS}: \mathrm{t}_{\mathrm{R}}=3.10 \mathrm{~min}$, MS $[\mathrm{M}+\mathrm{H}]^{+} m / z=467.9$. HRMS found 468.1547; $\mathrm{C}_{25} \mathrm{H}_{23} \mathrm{~F}_{2} \mathrm{~N}_{3} \mathrm{O}_{2} \mathrm{~S}$ requires 468.1557. ${ }^{1} \mathrm{H}$ NMR $\left(300 \mathrm{MHz}, \mathrm{CDCl}_{3}\right): \delta(\mathrm{ppm}) 2.90(\mathrm{~s}, 3 \mathrm{H}), 3.80(\mathrm{~s}, 3 \mathrm{H}), 3.82(\mathrm{~s}, 3 \mathrm{H}), 4.18(\mathrm{~s}, 2 \mathrm{H}), 6.17(\mathrm{dd}, J=$ 8.7, $2.8 \mathrm{~Hz}, 1 \mathrm{H}), 6.31(\mathrm{~d}, J=2.8 \mathrm{~Hz}, 1 \mathrm{H}), 6.70-6.83(\mathrm{~m}, 3 \mathrm{H}), 6.99-7.04(\mathrm{~m}, 3 \mathrm{H}), 7.18(\mathrm{~m}, 1 \mathrm{H})$, 7.25-7.32 (m, 3H). ${ }^{13} \mathrm{C}$ NMR (75 MHz, $\left.\mathrm{CDCl}_{3}\right): \delta(\mathrm{ppm}) 25.7,40.0,55.9,56.5,99.8,105.3$, $111.3(\mathrm{~m}), 112.4,113.6(\mathrm{t}, J=19.4 \mathrm{~Hz}), 124.2,127.3,128.7,128.9,129.1(\mathrm{t}, J=9.9 \mathrm{~Hz}), 134.9$, $138.3,139.5,142.6,143.3,149.6,161.3(\mathrm{dd}, J=249.8,7.4 \mathrm{~Hz})$.

\section{N-(3,4-Dimethoxy-phenyl)-2-[3-(4-methoxy-phenyl)-isothioureido]-N-methyl-acetamide}

(8d). 4-methoxyphenylisothiocyanate $(184.0 \mu \mathrm{L}, 1.33 \mathrm{mmol})$ and $\mathrm{NEt}_{3}(216 \mu \mathrm{L}, 1.60 \mathrm{mmol})$ were added in a $100 \mathrm{~mL}$ flask in $2 \mathrm{~mL}$ of ethanol. [2-(3,4-dimethoxy-N-methyl-anilino)-2-oxoethyl]ammonium formate $(\mathbf{3 c})(400 \mathrm{mg}, 1.33 \mathrm{mmol})$ was dissolved in $16 \mathrm{~mL}$ of ethanol, $\mathrm{NEt}_{3}$ $(180 \mu \mathrm{L}, 1.33 \mathrm{mmol})$ was added, and the mixture was added dropwise at room temperature. After the addition, the reaction was over. Reaction mixture was evaporated to dryness, and purified by flash chromatography using as eluent a mixture of $\mathrm{DCM} / \mathrm{MeOH}(99 / 1)$, to give the titled product as a yellowish powder $(157 \mathrm{mg}, 30 \%)$. MS $[\mathrm{M}+\mathrm{H}]^{+} \mathrm{m} / \mathrm{z}=389.9$.

\section{2-[2-(2,6-Difluoro-benzyl)-3-(4-methoxy-phenyl)-isothioureido]-N-(3,4-dimethoxy-phenyl)-}

N-methyl-acetamide (8e). The titled product was obtained as an orange solid (170 $\mathrm{mg}, 82 \%)$ without purification, following Procedure B, using N-(3,4-Dimethoxy-phenyl)-2-[3-(4-methoxy- 
phenyl)-isothioureido]-N-methyl-acetamide (8d) (157 mg, $400 \mu \mathrm{mol})$ and 2-Bromomethyl-1,3difluoro-benzene $(83 \mathrm{mg}, 400 \mu \mathrm{mol})$. MS $[\mathrm{M}+\mathrm{H}]^{+} \mathrm{m} / z=516.0 .{ }^{1} \mathrm{H}$ NMR $\left(300 \mathrm{MHz}, \mathrm{CDCl}_{3}\right): \delta$ (ppm) $3.28(\mathrm{~s}, 3 \mathrm{H}), 3.71(\mathrm{~s}, 3 \mathrm{H}), 3.82-3.88(\mathrm{~m}, 8 \mathrm{H}), 4.12(\mathrm{~s}, 2 \mathrm{H}), 6.70-6.85(\mathrm{~m}, 9 \mathrm{H}), 7.17$ (m, $1 \mathrm{H})$.

[2-(2,6-Difluoro-benzylsulfanyl)-3-(4-methoxy-phenyl)-3H-imidazol-4-yl]-(3,4-dimethoxy-

phenyl)-methyl-amine (8). 2-[2-(2,6-Difluoro-benzyl)-3-(4-methoxy-phenyl)-isothioureido]-N(3,4-dimethoxy-phenyl)-N-methyl-acetamide (8e) (170 mg, $0.33 \mathrm{mmol})$ was dissolved in $3.3 \mathrm{~mL}$ of EtOAc. DIEA (346 $\mu \mathrm{L}, 1.98 \mathrm{mmol})$, and T3P® in EtOAc $(583 \mu \mathrm{L}, 0.98 \mathrm{mmol})$ were then added. The mixture was heated under microwave irradiation at $150^{\circ} \mathrm{C}$ for $10 \mathrm{~min}$. Reaction mixture was then diluted with EtOAc, washed with a saturated aqueous solution of $\mathrm{NaHCO}_{3}$, and brine. Organic phase was then dried over $\mathrm{Na}_{2} \mathrm{SO}_{4}$ and evaporated to dryness. Residue was then purified by flash chromatography using as eluent a mixture of cyclohexane/EtOAc (85/15), to give the titled product a reddish solid $(77 \mathrm{mg}, 46 \%)$. LC-MS: $\mathrm{t}_{\mathrm{R}}=3.08 \mathrm{~min}$, MS $[\mathrm{M}+\mathrm{H}]^{+} \mathrm{m} / \mathrm{z}=$ 498.0. HRMS found 498.1672; $\mathrm{C}_{26} \mathrm{H}_{25} \mathrm{~F}_{2} \mathrm{~N}_{3} \mathrm{O}_{3}$ S requires 498.1663. ${ }^{1} \mathrm{H} \mathrm{NMR}\left(300 \mathrm{MHz}, \mathrm{CDCl}_{3}\right)$ : $\delta(\mathrm{ppm}) 2.91(\mathrm{~s}, 3 \mathrm{H}), 3.77(\mathrm{~s}, 3 \mathrm{H}), 3.80-3.81(\mathrm{~m}, 6 \mathrm{H}), 4.17(\mathrm{~s}, 2 \mathrm{H}), 6.16(\mathrm{dd}, J=8.7,2.8 \mathrm{~Hz}$, $1 \mathrm{H}), 6.30(\mathrm{~d}, J=2.7 \mathrm{~Hz}, 1 \mathrm{H}), 6.70-6.83(\mathrm{~m}, 5 \mathrm{H}), 6.93(\mathrm{~m}, 2 \mathrm{H}), 7.01(\mathrm{~s}, 1 \mathrm{H}), 7.18(\mathrm{~m}, 1 \mathrm{H}) .{ }^{13} \mathrm{C}$ NMR (75 MHz, $\left.\mathrm{CDCl}_{3}\right): \delta(\mathrm{ppm})$ 25.6, 39.9, 55.4, 55.9, 56.5, 99.6, 105.1, $111.2(\mathrm{~m}), 112.4$, $113.6(\mathrm{t}, J=19.6 \mathrm{~Hz}), 114.1,124.2,127.5,128.5,129.1(\mathrm{t}, J=10.4 \mathrm{~Hz}), 138.6,139.6,142.4$, $143.4,149.5,159.5,161.2(\mathrm{dd}, J=250.1,7.9 \mathrm{~Hz})$.

\section{N-(3,4-Dimethoxy-phenyl)-N-methyl-2-[3-(4-trifluoromethyl-phenyl)-isothioureido]-}

acetamide (9d). 4-(trifluomethyl)phenylisothiocyanate (332 mg, $1.63 \mathrm{mmol})$ and TEA (264 $\mu \mathrm{L}$, $1.96 \mathrm{mmol})$ were added in a $100 \mathrm{~mL}$ flask in $2 \mathrm{~mL}$ of ethanol. [2-(3,4-dimethoxy-N-methylanilino)-2-oxo-ethyl]ammonium formate (3c) $(490 \mathrm{mg}, 1.63 \mathrm{mmol})$ was dissolved in $18 \mathrm{~mL}$ of 
ethanol, $\mathrm{NEt}_{3}(220 \mu \mathrm{L}, 1.63 \mathrm{mmol})$ was added and the mixture was added dropwise at room temperature. After the addition, the reaction was over. Reaction mixture was evaporated to dryness, and purified by flash chromatography using as eluent a mixture of cyclohexane/EtOAc (6/4), to give the titled product as a yellowish powder $(352 \mathrm{mg}, 50 \%)$. MS $[\mathrm{M}+\mathrm{H}]^{+} \mathrm{m} / \mathrm{z}=427.9$. ${ }^{1} \mathrm{H}$ NMR (300 MHz, DMSO- $\left.d_{6}\right): \delta(\mathrm{ppm}) 3.18(\mathrm{~s}, 3 \mathrm{H}), 3.78$ (s, 3H), 3.79 (s, 3H), $4.02(\mathrm{~d}, J=3.8$ $\mathrm{Hz}, 2 \mathrm{H}), 6.93(\mathrm{dd}, J=8.5,2.2 \mathrm{~Hz}, 1 \mathrm{H}), 7.01-7.06(\mathrm{~m}, 2 \mathrm{H}), 7.65(\mathrm{~d}, J=8.6 \mathrm{~Hz}, 2 \mathrm{H}), 7.80(\mathrm{~d}, J=$ $8.6 \mathrm{~Hz}, 2 \mathrm{H}), 8.08(\mathrm{~s}, 1 \mathrm{H}), 10.3(\mathrm{~s}, 1 \mathrm{H})$.

\section{2-[2-(2,6-Difluoro-benzyl)-3-(4-trifluoromethyl-phenyl)-isothioureido]-N-(3,4-dimethoxy-}

phenyl)-N-methyl-acetamide (9e). The titled product was obtained as an orange solid (438 mg, $96 \%$ ) without purification, following Procedure B, using N-(3,4-Dimethoxy-phenyl)-N-methyl2-[3-(4-trifluoromethyl-phenyl)-isothioureido]-acetamide (9d) (352 mg) and 2-Bromomethyl1,3-difluoro-benzene (170 mg). MS $[\mathrm{M}+\mathrm{H}]^{+} m / z=554.0 .{ }^{1} \mathrm{H}$ NMR $\left(300 \mathrm{MHz}, \mathrm{DMSO}-d_{6}\right): \delta$ (ppm) $3.16(\mathrm{~s}, 3 \mathrm{H}), 3.68(\mathrm{~s}, 3 \mathrm{H}), 3.76(\mathrm{~m}, 5 \mathrm{H}), 4.21(\mathrm{~s}, 2 \mathrm{H}), 6.77-6.88(\mathrm{~m}, 3 \mathrm{H}), 6.95-6.99(\mathrm{~m}$, 2H), 7.05-7.11 (m, 3H), $7.39(\mathrm{~m}, 1 \mathrm{H}), 7.49(\mathrm{~d}, J=8.4 \mathrm{~Hz}, 2 \mathrm{H})$.

\section{[2-(2,6-Difluoro-benzylsulfanyl)-3-(4-trifluoromethyl-phenyl)-3H-imidazol-4-yl]-(3,4-}

dimethoxy-phenyl)-methyl-amine (9). 2-[2-(2,6-Difluoro-benzyl)-3-(4-trifluoromethylphenyl)-isothioureido]-N-(3,4-dimethoxy-phenyl)-N-methyl-acetamide $\quad$ (9e) (438 mg, 0.79 mmol) was dissolved in $8 \mathrm{~mL}$ of EtOAc. DIEA $(829 \mu \mathrm{L}, 4.75 \mathrm{mmol})$, and T3P® in EtOAc (1.40 $\mathrm{mL}, 2.37 \mathrm{mmol}$ ) were then added. The mixture was heated under microwave irradiation at $150^{\circ} \mathrm{C}$ for 10 min. Reaction mixture was then diluted with EtOAc, washed with a saturated aqueous solution of $\mathrm{NaHCO}_{3}$, and brine. Organic phase was then dried over $\mathrm{Na}_{2} \mathrm{SO}_{4}$ and evaporated to dryness. Residue was then purified by flash chromatography using as eluent a mixture of cyclohexane/EtOAc (85/15), to give the titled compound as an orange solid (166 mg, $39 \%)$. LC- 
MS: $t_{R}=3.42 \min$, MS $[\mathrm{M}+\mathrm{H}]^{+} m / z=535.9$. HRMS found 536.1433; $\mathrm{C}_{26} \mathrm{H}_{22} \mathrm{~F}_{5} \mathrm{~N}_{3} \mathrm{O}_{2} \mathrm{~S}$ requires 536.1431. ${ }^{1} \mathrm{H}$ NMR $\left(300 \mathrm{MHz}, \mathrm{CDCl}_{3}\right): \delta(\mathrm{ppm}) 2.92(\mathrm{~s}, 3 \mathrm{H}), 3.80(\mathrm{~s}, 3 \mathrm{H}), 3.83(\mathrm{~s}, 3 \mathrm{H}), 4.16(\mathrm{~s}$, 2H), $6.19(\mathrm{dd}, J=8.7,2.7 \mathrm{~Hz}, 1 \mathrm{H}), 6.31(\mathrm{~d}, J=2.7 \mathrm{~Hz}, 1 \mathrm{H}), 6.72(\mathrm{~d}, J=8.8 \mathrm{~Hz}, 1 \mathrm{H}), 6.79(\mathrm{~m}$, 2H), $7.06(\mathrm{~s}, 1 \mathrm{H}), 7.13(\mathrm{~d}, J=8.3 \mathrm{~Hz}, 2 \mathrm{H}), 7.18(\mathrm{~m}, 1 \mathrm{H}), 7.53(\mathrm{~d}, J=8.3 \mathrm{~Hz}, 2 \mathrm{H}) .{ }^{13} \mathrm{C}$ NMR $(75$ $\left.\mathrm{MHz}, \mathrm{CDCl}_{3}\right): \delta(\mathrm{ppm}) 26.3,40.3,56.0,56.5,100.2,106.0,111.4(\mathrm{~m}), 112.5,113.5(\mathrm{t}, J=19.3$ $\mathrm{Hz}), 123.7(\mathrm{q}, J=271.3 \mathrm{~Hz}), 126.1(\mathrm{q}, J=10.1 \mathrm{~Hz}), 130.6(\mathrm{q}, J=32.6 \mathrm{~Hz}), 137.9,138.0,139.8$, $143.0,149.7,161.2(\mathrm{dd}, J=250.0,7.4 \mathrm{~Hz})$.

tert-Butyl N-[2-(3,4-dimethoxy-N-methyl-anilino)-2-oxo-ethyl]carbamate (10b). In a $250 \mathrm{~mL}$ flask was added (3,4-dimethoxy-phenyl)-methyl-amine (3a) (903 mg, $5.405 \mathrm{mmol})$ in $4 \mathrm{~mL}$ of EtOAc. Then 2-(tert-butoxycarbonylamino)acetic acid (1136 mg, $6.486 \mathrm{mmol})$, T3Р® (4.777 $\mathrm{mL}, 5159 \mathrm{mmol})$ and DIEA $(2.832 \mathrm{~mL}, 16.21 \mathrm{mmol})$ were added. The mixture was stirred at room temperature for $30 \mathrm{~min}$. Then reaction mixture was diluted with EtOAc, washed with water, with a saturated aqueous solution of $\mathrm{NaHCO}_{3}$ and brine. The organic phase was dried over $\mathrm{MgSO}_{4}$, and evaporated to dryness, to give $1.77 \mathrm{~g}$ of reddish powder corresponding to the expected product, leading to a $100 \%$ yield. MS $[\mathrm{M}+\mathrm{H}]^{+} m / z=325.0 .{ }^{1} \mathrm{H}$ NMR $(300 \mathrm{MHz}$, $\left.\mathrm{CDCl}_{3}\right): \delta(\mathrm{ppm}) 1.42(\mathrm{~s}, 9 \mathrm{H}), 3.27(\mathrm{~s}, 3 \mathrm{H}), 3.68(\mathrm{~s}, 2 \mathrm{H}), 3.89(\mathrm{~m}, 6 \mathrm{H}), 6.68(\mathrm{~d}, J=2.4 \mathrm{~Hz}, 1 \mathrm{H})$, $6.76(\mathrm{dd}, J=8.4,2.4 \mathrm{~Hz}, 1 \mathrm{H}), 6.86(\mathrm{~d}, J=8.5 \mathrm{~Hz}, 1 \mathrm{H})$.

[2-(3,4-Dimethoxy-N-methyl-anilino)-2-oxo-ethyl] ammonium; 2,2,2-trifluoroacetate (10c). In a $50 \mathrm{~mL}$ flask tert-butyl $\mathrm{N}$-[2-(3,4-dimethoxy-N-methyl-anilino)-2-oxo-ethyl]carbamate (10b) (1770 mg, $5.458 \mathrm{mmol})$ was dissolved in $13.6 \mathrm{~mL}$ of DCM. TFA (5.526 mL, $72.21 \mathrm{mmol})$ was added and the reaction mixture was stirred at room temperature for 15 minutes. Reaction mixture was evaporated to dryness to give purple oil, corresponding to the expected product. Residue was used without further purification in the next step of the synthesis. MS $[\mathrm{M}+\mathrm{H}]^{+} m / z=225.1$. 


\section{$N$-(3,4-Dimethoxy-phenyl)-2-[3-(3-chloro-4-fluoro-phenyl)-isothioureido]- $N$-methyl-}

acetamide (10d). In a $100 \mathrm{~mL}$ flask were added 2-Chloro-1-fluoro-4-isothiocyanato-benzene $(318 \mathrm{mg}, 1.697 \mathrm{mmol})$ and $\mathrm{NEt}_{3}(0.275 \mathrm{~mL}, 2.036 \mathrm{mmol})$ in $5 \mathrm{~mL}$ of ethanol. A solution of [2(3,4-dimethoxy-N-methyl-anilino)-2-oxo-ethyl] ammonium; 2,2,2-trifluoroacetate (10c) (574 $\mathrm{mg}, 1.697 \mathrm{mmol})$ and $\mathrm{NEt}_{3}(0.229 \mathrm{~mL}, 1.697 \mathrm{mmol})$ in $20 \mathrm{~mL}$ of ethanol was added dropwise at room temperature. Reaction mixture was then evaporated to dryness and purified by flash chromatography using as eluent a mixture of $\mathrm{DCM} / \mathrm{MeOH}(98 / 2)$ to give the titled product as a pale green powder $(367 \mathrm{mg}, 53 \%)$. MS $[\mathrm{M}+\mathrm{H}]^{+} \mathrm{m} / \mathrm{z}=412.0 .{ }^{1} \mathrm{H}$ NMR $(300 \mathrm{MHz}, \mathrm{DMSO}-d 6): \delta$ (ppm) 3.17 (s, 3H), 3.77 (s, 3H), 3.79 (s, 3H), 4.00 (d, J=4.2 Hz, 2H), 6.93 (dd, J = 8.4, 2.3 Hz, 1H), 7.34-7.36 (m, 2H), 7.84-7.95 (m, 2H), $10.05(\mathrm{~s}, 1 \mathrm{H})$.

\section{2-[2-(2,6-Difluoro-benzyl)-3-(3-chloro-4-fluoro-phenyl)-isothioureido]-N-(3,4-dimethoxy-}

phenyl)-N-methyl-acetamide (10e). The titled product was obtained as an orange oil (238 mg, $99 \%)$ without purification, following Procedure B, using $N$-(3,4-dimethoxy-phenyl)-2-[3-(3chloro-4-fluoro-phenyl)-isothioureido]- $N$-methyl-acetamide $\quad(\mathbf{1 0 d}) \quad\left(\begin{array}{lll}184 & \mathrm{mg}\end{array}\right) \quad$ and $\quad 2-$ Bromomethyl-1,3-difluoro-benzene $(92 \mathrm{mg})$. MS $[\mathrm{M}+\mathrm{H}]^{+} \mathrm{m} / \mathrm{z}=$ 538.1. ${ }^{1} \mathrm{H}$ NMR $(300 \mathrm{MHz}$, $\left.\mathrm{CDCl}_{3}\right): \delta(\mathrm{ppm}) 3.29(\mathrm{~s}, 3 \mathrm{H}), 3.79-3.93(\mathrm{~m}, 8 \mathrm{H}), 4.13(\mathrm{~s}, 2 \mathrm{H}), 6.57-7.00(\mathrm{~m}, 9 \mathrm{H})$, 7.15-7.27 (m, $1 \mathrm{H})$.

\section{[2-(2,6-Difluoro-benzylsulfanyl)-3-(3-chloro-4-fluoro-phenyl)-3H-imidazol-4-yl]-(3,4-}

dimethoxy-phenyl)-methyl-amine (10). The titled product is obtained as an orange powder (126 mg, 55\%), following Procedure C, using 2-[2-(2,6-Difluoro-benzyl)-3-(3-chloro-4-fluorophenyl)-isothioureido]-N-(3,4-dimethoxy-phenyl)-N-methyl-acetamide (10e) (238 mg). LC-MS: $\mathrm{t}_{\mathrm{R}}=3.55 \mathrm{~min}$, MS $[\mathrm{M}+\mathrm{H}]^{+} \mathrm{m} / \mathrm{z}=520.1$. HRMS found 520.1063; $\mathrm{C}_{25} \mathrm{H}_{21}{ }^{35} \mathrm{ClF}_{3} \mathrm{~N}_{3} \mathrm{O}_{2} \mathrm{~S}$ requires 520.1073. ${ }^{1} \mathrm{H}$ NMR $\left(300 \mathrm{MHz}, \mathrm{CDCl}_{3}\right): \delta(\mathrm{ppm}) 2.96(\mathrm{~s}, 3 \mathrm{H}), 3.80(\mathrm{~s}, 3 \mathrm{H}), 3.82(\mathrm{~s}, 3 \mathrm{H}), 4.14(\mathrm{~s}$, 
2H), $6.15(\mathrm{dd}, J=8.7,2.7 \mathrm{~Hz}, 1 \mathrm{H}), 6.71(\mathrm{~d}, J=8.7 \mathrm{~Hz}, 1 \mathrm{H}), 6.77-6.89(\mathrm{~m}, 3 \mathrm{H}), 6.91(\mathrm{dd}, J=$ 6.4, $2.5 \mathrm{~Hz}, 1 \mathrm{H}), 7.01(\mathrm{t}, J=8.5 \mathrm{~Hz}, 1 \mathrm{H}), 7.03(\mathrm{~s}, 1 \mathrm{H}), 7.20(\mathrm{~m}, 1 \mathrm{H}) .{ }^{13} \mathrm{C} \mathrm{NMR}(75 \mathrm{MHz}$, $\left.\mathrm{CDCl}_{3}\right): \delta(\mathrm{ppm}) 26.3,40.6,56.0,56.5,100.6,106.5,111.3(\mathrm{~m}), 112.3,113.6(\mathrm{t}, J=19.4 \mathrm{~Hz})$ $116.6(\mathrm{~d}, J=22.4 \mathrm{~Hz}), 121.2(\mathrm{~d}, J=19.1 \mathrm{~Hz}), 124.0,127.5(\mathrm{~d}, J=7.7 \mathrm{~Hz}), 129.3(\mathrm{t}, J=10.2$ $\mathrm{Hz}), 129.7,131.4(\mathrm{~d}, J=3.9 \mathrm{~Hz}), 137.9,139.9,142.9,143.2,149.7,157.8(\mathrm{~d}, J=251.7 \mathrm{~Hz})$, $161.1(\mathrm{dd}, J=249.7,7.6 \mathrm{~Hz})$.

\section{$N$-(3,4-Dimethoxy-phenyl)-2-[3-(2,4-difluoro-phenyl)-isothioureido]- $N$-methyl-acetamide}

(11d). In a 100mL flask were added 2,4-difluoro-1-isothiocyanato-benzene (290 mg, 1.698 $\mathrm{mmol})$ and $\mathrm{NEt}_{3}(0.275 \mathrm{~mL}, 2.037 \mathrm{mmol})$ in $5 \mathrm{~mL}$ of ethanol. A solution of [2-(3,4-dimethoxyN-methyl-anilino)-2-oxo-ethyl] ammonium; 2,2,2-trifluoroacetate (10c) (574 mg, $1.698 \mathrm{mmol})$ and $\mathrm{NEt}_{3}(0.229 \mathrm{~mL}, 1.698 \mathrm{mmol})$ in $20 \mathrm{~mL}$ of ethanol was added dropwise at room temperature. Reaction mixture was then evaporated to dryness. Residue was then purified by flash chromatography using as eluent a mixture of DCM/ methanol (98/2) to give $335 \mathrm{mg}$ of a yellowish powder corresponding to the expected product, leading to a $50 \%$ yield. MS $[\mathrm{M}+\mathrm{H}]^{+}$ $m / z=396.1 .{ }^{1} \mathrm{H}$ NMR $\left(300 \mathrm{MHz}, \mathrm{DMSO}-d_{6}\right): \delta(\mathrm{ppm}) 3.16$ (s, 3H), $3.76(\mathrm{~s}, 3 \mathrm{H}), 3.78(\mathrm{~s}, 3 \mathrm{H})$, $4.00(\mathrm{~s}, 2 \mathrm{H}), 6.90-7.08(\mathrm{~m}, 4 \mathrm{H}), 7.29(\mathrm{~m}, 1 \mathrm{H}), 7.62(\mathrm{~m}, 1 \mathrm{H}), 7.98$ (brs, 1H), 9.59 (brs, 1H).

\section{2-[2-(2,6-Difluoro-benzyl)-3-(2,4-difluoro-phenyl)-isothioureido]-N-(3,4-dimethoxy-}

phenyl)-N-methyl-acetamide (11e). The titled product was obtained as a yellowish oil (413 mg, $93 \%)$ without purification, following Procedure B, using N-(3,4-dimethoxy-phenyl)-2-[3-(2,4difluoro-phenyl)-isothioureido]- $N$-methyl-acetamide (11d) $(335 \mathrm{mg}$ ) and 2-Bromomethyl-1,3difluoro-benzene $(175 \mathrm{mg})$. MS $[\mathrm{M}+\mathrm{H}]^{+} \mathrm{m} / z=522.2 .{ }^{1} \mathrm{H} \mathrm{NMR}\left(300 \mathrm{MHz}, \mathrm{CDCl}_{3}\right): \delta$ (ppm) 3.31 (s, 3H), 3.83-3.99 (m, 8H), $4.18(\mathrm{~s}, 2 \mathrm{H}), 6.65-6.93(\mathrm{~m}, 9 \mathrm{H})$, 7.17-7.25 (m, 1H). 
[2-(2,6-Difluoro-benzylsulfanyl)-3-(2,4-difluoro-phenyl)-3H-imidazol-4-yl]-(3,4-dimethoxy-

phenyl)-methyl-amine (11). The titled product is obtained as a reddish solid (226 mg, 56\%), following Procedure C, using 2-[2-(2,6-Difluoro-benzyl)-3-(2,4-difluoro-phenyl)-isothioureido]$\mathrm{N}$-(3,4-dimethoxy-phenyl)-N-methyl-acetamide (11e) $(413 \mathrm{mg})$. LC-MS: $\mathrm{t}_{\mathrm{R}}=3.47 \mathrm{~min}, \mathrm{MS}$ $[\mathrm{M}+\mathrm{H}]^{+} m / z=504.1$. HRMS found 504.1382; $\mathrm{C}_{25} \mathrm{H}_{21} \mathrm{~F}_{4} \mathrm{~N}_{3} \mathrm{O}_{2} \mathrm{~S}$ requires 504.1369. ${ }^{1} \mathrm{H}$ NMR (300 $\left.\mathrm{MHz}, \mathrm{CDCl}_{3}\right): \delta(\mathrm{ppm}) 3.02(\mathrm{~s}, 3 \mathrm{H}), 3.77(\mathrm{~s}, 3 \mathrm{H}), 3.80(\mathrm{~s}, 3 \mathrm{H}), 4.17(\mathrm{~m}, 2 \mathrm{H}), 6.14(\mathrm{dd}, J=8.7$, $2.8 \mathrm{~Hz}, 1 \mathrm{H}), 6.25(\mathrm{~d}, J=2.8 \mathrm{~Hz}, 1 \mathrm{H}), 6.64-6.76(\mathrm{~m}, 2 \mathrm{H}), 6.77-6.87(\mathrm{~m}, 4 \mathrm{H}), 7.05(\mathrm{~s}, 1 \mathrm{H}), 7.20$

(m, 1H). ${ }^{13} \mathrm{C} \mathrm{NMR}\left(75 \mathrm{MHz}, \mathrm{CDCl}_{3}\right): \delta(\mathrm{ppm})$ 26.2, 40.7, 55.8, 56.4, 100.6, $104.9(\mathrm{dd}, J=26.4$, $23.7 \mathrm{~Hz}), 106.2,111.1-112.1(\mathrm{~m}), 113.7(\mathrm{t}, J=19.4 \mathrm{~Hz}), 119.1(\mathrm{dd}, J=13.0,4.1 \mathrm{~Hz}), 123.8$, $129.2(\mathrm{t}, J=10.3 \mathrm{~Hz}), 130.5(\mathrm{~d}, J=10.2 \mathrm{~Hz}), 138.7,140.4,142.7,143.0,149.4,157.8(\mathrm{dd}, J=$ 255.1, $12.9 \mathrm{~Hz}), 161.2(\mathrm{dd}, J=250.2,7.5 \mathrm{~Hz}), 162.9(\mathrm{dd}, J=252.4,11.3 \mathrm{~Hz})$.

\section{$N$-(3,4-Dimethoxy-phenyl)-2-[3-(4-fluoro-3-methoxy-phenyl)-isothioureido]- $N$-methyl-}

acetamide (12d). In a $25 \mathrm{~mL}$ flask, TCDI $(133 \mathrm{mg}, 0.749 \mathrm{mmol})$ was dissolved in $3 \mathrm{~mL}$ of dioxane. [2-(3,4-dimethoxy-N-methyl-anilino)-2-oxo-ethyl] ammonium; 2,2,2-trifluoroacetate (10b) (230 $\mathrm{mg}, 0.681 \mathrm{mmol})$ in $3.50 \mathrm{~mL}$ of dioxane was then added dropwise. The solution was then stirred at room temperature for 1.5 hours. 4-fluoro-3-methoxy-aniline (106 mg, 0.750 mmol) and $\mathrm{NEt}_{3}(285 \mu \mathrm{L}, 2.04 \mathrm{mmol})$ were added to the solution. Reaction mixture was stirred at $60^{\circ} \mathrm{C}$ overnight. Solvent was then removed. Residue was dissolved in EtOAc, and washed with water, with an aqueous $\mathrm{HCl} 0.1 \mathrm{~N}$ solution, and dried over $\mathrm{MgSO}_{4}$. After evaporation, residue was purified by flash chromatography using as eluent a mixture of cyclohexane/EtOAc (8/2) to give the titled product as an orange solid $(136 \mathrm{mg}, 49 \%)$. MS $[\mathrm{M}+\mathrm{H}]^{+} \mathrm{m} / \mathrm{z}=408.1 .{ }^{1} \mathrm{H} \mathrm{NMR}$ (300 MHz, DMSO- $\left.d_{6}\right): \delta(\mathrm{ppm}) 3.16(\mathrm{~s}, 3 \mathrm{H}), 3.74-3.82(\mathrm{~m}, 9 \mathrm{H}), 4.00(\mathrm{~d}, J=4.2 \mathrm{~Hz}, 2 \mathrm{H}) ; 6.84-$ 
$6.96(\mathrm{~m}, 2 \mathrm{H}), 6.98-7.06(\mathrm{~m}, 2 \mathrm{H}), 7.15(\mathrm{dd}, J=11.3,8.7 \mathrm{~Hz}, 1 \mathrm{H}), 7.37(\mathrm{dd}, J=7.9,2.2 \mathrm{~Hz}, 1 \mathrm{H})$, 7.77 (brs, 1H), 9.91 (s, 1H).

2-[2-(2,6-Difluoro-benzyl)-3-(4-fluoro-3-methoxy-phenyl)-isothioureido]-N-(3,4-dimethoxyphenyl)-N-methyl-acetamide (12e). The titled product was obtained as a yellowish oil (156 mg, 91\%) without purification, following Procedure B, using $N$-(3,4-dimethoxy-phenyl)-2-[3-(4fluoro-3-methoxy-phenyl)-isothioureido]- $N$-methyl-acetamide $\quad(\mathbf{1 2 d}) \quad(124 \quad \mathrm{mg}) \quad$ and $\quad 2$ Bromomethyl-1,3-difluoro-benzene $(63 \mathrm{mg}) . \mathrm{MS}[\mathrm{M}+\mathrm{H}]^{+} \mathrm{m} / \mathrm{z}=534.2 .{ }^{1} \mathrm{H} \mathrm{NMR}(300 \mathrm{MHz}$, $\left.\mathrm{CDCl}_{3}\right): \delta(\mathrm{ppm}) 3.28(\mathrm{~s}, 3 \mathrm{H}), 3.78-3.84(\mathrm{~m}, 11 \mathrm{H}), 4.11$ (brs, 2H), $5.82(\mathrm{~s}, 1 \mathrm{H}), 6.29$ (brs, 1H), $6.44(\mathrm{~d}, J=6.3 \mathrm{~Hz}, 1 \mathrm{H}), 6.61-6.89(\mathrm{~m} 6 \mathrm{H}), 7.13-7.26(\mathrm{~m}, 1 \mathrm{H})$.

\section{[2-(2,6-Difluoro-benzylsulfanyl)-3-(4-fluoro-3-methoxy-phenyl)-3H-imidazol-4-yl]-(3,4-}

dimethoxy-phenyl)-methyl-amine (12). The titled product is obtained as an orange powder (143 mg, 63\%), following Procedure C, using 2-[2-(2,6-Difluoro-benzyl)-3-(4-fluoro-3methoxy-phenyl)-isothioureido]-N-(3,4-dimethoxy-phenyl)-N-methyl-acetamide (12e) (156 mg). LC-MS: $t_{R}=3.42 \min , \operatorname{MS}[M+H]^{+} m / z=516.2$. HRMS found 516.1558; $\mathrm{C}_{26} \mathrm{H}_{24} \mathrm{~F}_{3} \mathrm{~N}_{3} \mathrm{O}_{3} \mathrm{~S}$ requires 516.1569. ${ }^{1} \mathrm{H} \mathrm{NMR}\left(300 \mathrm{MHz}, \mathrm{CDCl}_{3}\right): \delta(\mathrm{ppm}) 2.90(\mathrm{~s}, 3 \mathrm{H}), 3.54(\mathrm{~s}, 3 \mathrm{H}), 3.82(\mathrm{~s}, 6 \mathrm{H})$, $4.20(\mathrm{~s}, 2 \mathrm{H}), 6.18(\mathrm{dd}, J=8.7,2.8 \mathrm{~Hz}, 1 \mathrm{H}), 6.33(\mathrm{~d}, J=2.8 \mathrm{~Hz}, 1 \mathrm{H}), 6.54(\mathrm{dd}, J=7.5,2.4 \mathrm{~Hz}$, 1H), 6.59-6.64 (m, 1H), $6.75(\mathrm{~d}, J=8.7 \mathrm{~Hz}, 1 \mathrm{H}), 6.78-6.86(\mathrm{~m}, 2 \mathrm{H}), 6.98(\mathrm{dd}, J=10.8,8.6 \mathrm{~Hz}$, 1H), $7.06(\mathrm{~s}, 1 \mathrm{H}), 7.14-7.24(\mathrm{~m}, 1 \mathrm{H}) .{ }^{13} \mathrm{C} \mathrm{NMR}\left(75 \mathrm{MHz}, \mathrm{CDCl}_{3}\right): \delta(\mathrm{ppm})$ 25.7, 39.9, 55.9, 56.0, 56.6, 99.7, 105.2, 111.1-111.4 (m), 112.6, 112.7 (d, $J=2.4 \mathrm{~Hz}), 113.6(\mathrm{t}, J=19.4 \mathrm{~Hz})$, $115.9(\mathrm{~d}, J=19.6 \mathrm{~Hz}), 119.7(\mathrm{~d}, J=7.3 \mathrm{~Hz}), 124.9,129.2(\mathrm{t}, J=10.2 \mathrm{~Hz}), 130.9(\mathrm{~d}, J=3.6 \mathrm{~Hz})$, 138.6, 139.0, 142.6, 143.5, $147.5(\mathrm{~d}, J=11.6 \mathrm{~Hz}), 149.8,152.0(\mathrm{~d}, J=248.9 \mathrm{~Hz}), 161.2(\mathrm{dd}, J=$ 249.9, $7.7 \mathrm{~Hz}$ ). 
(4-Chloro-3-methoxy-phenyl)-methyl-amine (13a). In a $50 \mathrm{~mL}$ flask were added 4-Chloro-3methoxy-phenylamine (907 mg), sodium methoxide (1.56 g), $10 \mathrm{~mL}$ anhydrous methanol, and paraformaldehyde $(690 \mathrm{mg})$. Reaction mixture was then stirred overnight at room temperature. Then, paraformaldehyde (173 mg) and sodium methoxyde (311 mg) were added, and reaction mixture was heated at reflux for 1 hour. Sodium borohydride (436 mg) was then added, and reaction mixture was stirred at reflux for 4 hours. Once back at room temperature, mixture was partially evaporated, and aqueous $\mathrm{KOH} 1 \mathrm{M}(50 \mathrm{~mL})$ was then added. The obtained suspension was extracted by $\mathrm{Et}_{2} \mathrm{O}$, organic phase was dried over $\mathrm{Na}_{2} \mathrm{SO}_{4}$ and evaporated. The obtained residue was purified by flash chromatography using as eluent a mixture of cyclohexane/EtOAc $(8 / 2)$ to give the titled product as a brown powder $(650 \mathrm{mg}, 66 \%)$. MS $[\mathrm{M}+\mathrm{H}]^{+} \mathrm{m} / \mathrm{z}=171.9 .{ }^{1} \mathrm{H}$ NMR (300 MHz, DMSO- $\left.d_{6}\right): \delta(\mathrm{ppm}) 2.66(\mathrm{~d}, J=4.9 \mathrm{~Hz}, 3 \mathrm{H}), 3.77(\mathrm{~s}, 3 \mathrm{H}), 5.80(\mathrm{q}, J=4.9 \mathrm{~Hz}$, $1 \mathrm{H}), 6.09(\mathrm{dd}, J=8.7,2.5 \mathrm{~Hz}, 1 \mathrm{H}), 6.25(\mathrm{~d}, J=2.4 \mathrm{~Hz}, 1 \mathrm{H}), 7.04(\mathrm{~d}, J=8.7 \mathrm{~Hz}, 1 \mathrm{H})$.

2-Chloro-N-(4-chloro-3-methoxy-phenyl)-N-methyl-acetamide (13b). In a $100 \mathrm{~mL}$ flask were introduced a solution of $620 \mathrm{mg}$ of (4-Chloro-3-methoxy-phenyl)-methyl-amine (13a) and 1.7 $\mathrm{mL}$ of DIEA in $18 \mathrm{~mL}$ of DCM (dried over $\mathrm{Na}_{2} \mathrm{SO}_{4}$ ). The solution was stirred at $0^{\circ} \mathrm{C}$. Then, a solution of $568 \mu \mathrm{L}$ of chloroacetyl chloride in $14 \mathrm{~mL}$ of DCM (dried over $\mathrm{Na}_{2} \mathrm{SO}_{4}$ ) was added dropwise in the flask. The mixture was then evaporated to dryness to give a brown residue which was used without further purification in the next step of the synthesis. MS $[\mathrm{M}+\mathrm{H}]^{+} \mathrm{m} / z=248.0$.

2-Amino-N-(4-chloro-3-methoxy-phenyl)-N-methyl-acetamide (13c). Residue corresponding to 2-Chloro-N-(4-chloro-3-methoxy-phenyl)-N-methyl-acetamide $\quad(\mathbf{1 3 b}) \quad(3.6 \mathrm{mmol})$ was dissolved in $6 \mathrm{~mL}$ EtOH $95^{\circ}$. The obtained solution was added dropwise in aqueous ammonia $(30 \% \mathrm{w} / \mathrm{w}, 75 \mathrm{~mL})$ at $65^{\circ} \mathrm{C}$. After 1 hour stirring at $65^{\circ} \mathrm{C}$, reaction mixture was evaporated. The residue was dissolved in water, $\mathrm{pH}$ was adjusted to 10 , and the solution was extracted several 
times by DCM. Organic phases were dried over over $\mathrm{Na}_{2} \mathrm{SO}_{4}$ and evaporated, to give a brown oily residue. It was used without further purification in the next step of the synthesis. MS $[\mathrm{M}+\mathrm{H}]^{+} m / z=229.0$.

\section{N-(4-Chloro-3-methoxy-phenyl)-2-[3-(4-fluoro-phenyl)-isothioureido]-N-methyl-acetamide}

(13d). In a $250 \mathrm{~mL}$ flask, 4-fluorophenylisothiocyanate $(551.4 \mathrm{mg})$ and $\mathrm{NEt}_{3}(583 \mu \mathrm{L})$ were dissolved in $3 \mathrm{~mL}$ of ethanol. A solution 2-amino-N-(4-chloro-3-methoxy-phenyl)-N-methylacetamide (13c) in $48 \mathrm{~mL}$ of ethanol was added dropwise at room temperature. After 1 hour stirring at room temperature, mixture was evaporated to dryness, and residue was purified by flash chromatography using as eluent a mixture of cyclohexane/DCM (1/1) to pure DCM. The titled product was obtained as a yellowish powder (546 mg, $39 \%$ yield over the 3 steps). MS $[\mathrm{M}+\mathrm{H}]^{+} \mathrm{m} / z=382.1 .{ }^{1} \mathrm{H}$ NMR $\left(300 \mathrm{MHz}, \mathrm{DMSO}-d_{6}\right): \delta(\mathrm{ppm}) 3.21(\mathrm{~s}, 3 \mathrm{H}), 3.88(\mathrm{~s}, 3 \mathrm{H}), 4.06$ (brs, 2H), $7.01(\mathrm{~m}, 1 \mathrm{H}), 7.16(\mathrm{~m}, 2 \mathrm{H}), 7.26(\mathrm{brs}, 1 \mathrm{H}), 7.45(\mathrm{~m}, 2 \mathrm{H}), 7.52(\mathrm{~d}, J=8.3 \mathrm{~Hz}, 1 \mathrm{H})$, 7.76 (brs, 1H), 9.90 (brs, 1H).

\section{N-(4-Chloro-3-methoxy-phenyl)-2-[2-(2,6-difluoro-benzyl)-3-(4-fluoro-phenyl)-}

isothioureido]-N-methyl-acetamide (13e). The titled product was obtained as an oily residue (603 mg, $87 \%$ ), without purification, following Procedure B, using N-(4-Chloro-3-methoxyphenyl)-2-[3-(4-fluoro-phenyl)-isothioureido]-N-methyl-acetamide (13d) (468 mg) and 2Bromomethyl-1,3-difluoro-benzene (254 mg). MS $[\mathrm{M}+\mathrm{H}]^{+} \mathrm{m} / z=508.2 .{ }^{1} \mathrm{H}$ NMR $(300 \mathrm{MHz}$, DMSO- $\left.d_{6}\right): \delta(\mathrm{ppm}) 3.20(\mathrm{~s}, 3 \mathrm{H}), 3.79-3.89(\mathrm{~m}, 5 \mathrm{H}), 4.19(\mathrm{~s}, 2 \mathrm{H}), 6.23$ (brs, 2H), 6.95-7.10 (m, 6H), $7.18(\mathrm{~s}, 1 \mathrm{H}), 7.38(\mathrm{~m}, 1 \mathrm{H}), 7.48(\mathrm{~m}, 1 \mathrm{H})$.

(4-Chloro-3-methoxy-phenyl)-[2-(2,6-difluoro-benzylsulfanyl)-3-(4-fluoro-phenyl)-3Himidazol-4-yl]-methyl-amine (13). In a microwave tube were introduced N-(4-Chloro-3methoxy-phenyl)-2-[2-(2,6-difluoro-benzyl)-3-(4-fluoro-phenyl)-isothioureido]-N-methyl- 
acetamide (13e) $(145 \mathrm{mg}), 3 \mathrm{~mL}$ of EtOAc, DIEA $(74,8 \mu \mathrm{L})$, and T3P® $(168 \mu \mathrm{L})$. Reaction mixture was then heated twice under microwave irradiation, at $100^{\circ} \mathrm{C}$ for $10 \mathrm{~min}$. T3P® $(348$ $\mu \mathrm{L})$ and DIEA (206 $\mu \mathrm{L})$ were then added, and the mixture was heated at $150^{\circ} \mathrm{C}$ for $20 \mathrm{~min}$ under microwave irradiation. Reaction mixture was washed with a saturated aqueous solution of $\mathrm{NaHCO}_{3}$, and brine. Organic phase was dried over $\mathrm{Na}_{2} \mathrm{SO}_{4}$ and evaporated. The obtained residue was purified by flash chromatography using as eluent a mixture of DCM/cyclohexane and then $\mathrm{DCM} / \mathrm{MeOH}$ to give a yellowish residue corresponding to the titled product $(83 \mathrm{mg}, 59 \%)$. LCMS: $t_{R}=3.77 \mathrm{~min}$, MS $[\mathrm{M}+\mathrm{H}]^{+} \mathrm{m} / \mathrm{z}=508.2$. HRMS found 490.0953; $\mathrm{C}_{24} \mathrm{H}_{19}{ }^{35} \mathrm{ClF}_{3} \mathrm{~N}_{3} \mathrm{OS}$ requires 490.0968. ${ }^{1} \mathrm{H}$ NMR (300 MHz, DMSO- $\left.d_{6}\right): \delta(\mathrm{ppm}) 2.96(\mathrm{~s}, 3 \mathrm{H}), 3.75$ (s, 3H), 4.08 (s, 2H), $6.09(\mathrm{dd}, J=8.8,2.7 \mathrm{~Hz}, 1 \mathrm{H}), 6.27(\mathrm{~d}, J=2.6 \mathrm{~Hz}, 1 \mathrm{H}), 7.02-7.07(\mathrm{~m}, 3 \mathrm{H}), 7.11-7.15(\mathrm{~m}$, 3H), $7.21(\mathrm{~m}, 2 \mathrm{H}), 7.37(\mathrm{~m}, 1 \mathrm{H}) .{ }^{13} \mathrm{C}$ NMR (75 MHz, DMSO- $\left.d_{6}\right): \delta(\mathrm{ppm}) 26.0,26.8,56.2,98.2$, $106.4,110.7,112.1(\mathrm{~d}, J=23.9 \mathrm{~Hz}), 113.8(\mathrm{t}, J=19.9 \mathrm{~Hz}), 116.5(\mathrm{~d}, J=23.2 \mathrm{~Hz}), 125.2,130.0$, $130.1(\mathrm{~d}, J=9.1 \mathrm{~Hz}), 130.5(\mathrm{t}, J=10.9 \mathrm{~Hz}), 131.2,137.9,138.6,149.0,155.3,161.0(\mathrm{dd}, J=$ $248.8,7.4 \mathrm{~Hz}), 162.3(\mathrm{~d}, J=245.9 \mathrm{~Hz})$.

tert-Butyl $N$-[2-(4-methoxy- $N$-methyl-anilino)-2-oxo-ethyl]carbamate (14b). In a $25 \mathrm{~mL}$ flask was added 4-methoxy-N-methyl-aniline $(274 \mathrm{mg}, 2 \mathrm{mmol})$ in $4 \mathrm{~mL}$ of EtOAc. Then 2-(tertbutoxycarbonylamino)acetic acid $(420 \mathrm{mg}, 2.4 \mathrm{mmol}), \mathrm{T} 3 \mathrm{P} 囚(1.768 \mathrm{~mL}, 3 \mathrm{mmol})$ and DIEA (1.048 $\mathrm{mL}, 6 \mathrm{mmol})$ were added. The mixture was stirred for $30 \mathrm{~min}$ at room temperature. Then the reaction mixture was diluted with EtOAc, washed with water, with a saturated aqueous solution of $\mathrm{NaHCO}_{3}$ and brine. The organic phase was dried over $\mathrm{MgSO}_{4}$, filtered and then evaporated, to give the titled product as a bronze solid (463 mg, $79 \%$ ). MS $[\mathrm{M}+\mathrm{H}]^{+} \mathrm{m} / \mathrm{z}=295.1$.

[2-(4-Methoxy- $N$-methyl-anilino)-2-oxo-ethyl] ammonium; 2,2,2-trifluoroacetate (14c). Tert-butyl $N$-[2-(4-methoxy- $N$-methyl-anilino)-2-oxo-ethyl]carbamate (14b) (463.70 mg, 1.575 
mmol) was dissolved in $4 \mathrm{~mL}$ of DCM. TFA (20.84 mmol, $1.595 \mathrm{~mL})$ was added and the reaction mixture was stirred at room temperature for 30 minutes. Solvent was removed to give viscous reddish oil. $510 \mathrm{mg}$ of residue was obtained corresponding to the expected product and to a rest of 4-methoxy-N-methyl-aniline. Residue was used in the next step without further purification. MS $[\mathrm{M}+\mathrm{H}]^{+} \mathrm{m} / \mathrm{z}=195.0 .{ }^{1} \mathrm{H}$ NMR $\left(300 \mathrm{MHz}, \mathrm{CDCl}_{3}\right): \delta(\mathrm{ppm}) 3.20(\mathrm{~s}, 3 \mathrm{H}), 3.57$ $(\mathrm{s}, 2 \mathrm{H}), 3.83(\mathrm{~s}, 3 \mathrm{H}), 6.95(\mathrm{~d}, J=8.9 \mathrm{~Hz}, 2 \mathrm{H}), 7.12(\mathrm{~d}, J=9.0 \mathrm{~Hz}, 2 \mathrm{H}), 7.80(\mathrm{~s}, 3 \mathrm{H})$.

$N$-(4-Methoxy-phenyl)-2-[3-(4-fluoro-phenyl)-isothioureido]- $N$-methyl-acetamide (14d). In a $100 \mathrm{~mL}$ flask were added 4-fluorophenylisothiocyanate $(1.575 \mathrm{mmol}, 241 \mathrm{mg})$ and $\mathrm{NEt}_{3}(1.890$ mmol, $0.255 \mathrm{~mL}$ ) in $5 \mathrm{~mL}$ of ethanol. A solution of [2-(4-methoxy- $N$-methyl-anilino)-2-oxoethyl] ammonium; 2,2,2-trifluoroacetate (14c) $(1.575 \mathrm{mmol}, 485 \mathrm{mg})$ and $\mathrm{NEt}_{3}(1.575 \mathrm{mmol}$, $0.213 \mathrm{~mL}$ ) in $20 \mathrm{~mL}$ of ethanol was added dropwise at room temperature. Reaction mixture was evaporated to dryness to give $865 \mathrm{mg}$ of pale green powder, corresponding to the titled product. Residue was used without further purification in the next step of the synthesis. MS $[\mathrm{M}+\mathrm{H}]^{+} \mathrm{m} / \mathrm{z}$ $=348.0$.

2-[2-(2,6-Difluoro-benzyl)-3-(4-fluoro-phenyl)-isothioureido]-N-(4-methoxy-phenyl)-Nmethyl-acetamide (14e). The titled product was obtained without purification as yellow oil (727 mg, $97 \%$ ) following procedure B, using $N$-(4-methoxy-phenyl)-2-[3-(4-fluoro-phenyl)isothioureido]- $N$-methyl-acetamide (14d) (547 mg) and 2-(bromomethyl)-1,3-difluoro-benzene (513 mg). MS $[\mathrm{M}+\mathrm{H}]^{+} \mathrm{m} / z=475.1$.

[2-(2,6-Difluoro-benzylsulfanyl)-3-(4-fluoro-phenyl)-3H-imidazol-4-yl]-(4-methoxy-phenyl)methyl-amine (14). The titled product was obtained as an orange powder (120 mg, 17\%), following Procedure C, using 2-[2-(2,6-Difluoro-benzyl)-3-(4-fluoro-phenyl)-isothioureido]-N(4-methoxy-phenyl)-N-methyl-acetamide (14e) $(726 \mathrm{mg})$ LC-MS : $\mathrm{t}_{\mathrm{R}}=3.59 \mathrm{~min} ; \mathrm{MS}[\mathrm{M}+\mathrm{H}]^{+}$ 
$m / z=456.1$. HRMS found 456.1369; $\mathrm{C}_{24} \mathrm{H}_{20} \mathrm{~F}_{3} \mathrm{~N}_{3} \mathrm{OS}$ requires 456.1357. ${ }^{1} \mathrm{H}$ NMR $(300 \mathrm{MHz}$, $\left.\mathrm{CDCl}_{3}\right): \delta(\mathrm{ppm}) 2.92(\mathrm{~s}, 3 \mathrm{H}), 3.76(\mathrm{~s}, 3 \mathrm{H}), 4.18$ (brs, 2H), 6.57-6.60 (m, 2H), 6.70-6.77 (m, 2H), 6.80-6.86 (m, 2H), 6.92-6.95 (m, 4H), $7.00(\mathrm{~s}, 1 \mathrm{H}), 7.15-7.23(\mathrm{~m}, 1 \mathrm{H}) .{ }^{13} \mathrm{C} \mathrm{NMR}(75 \mathrm{MHz}$, $\left.\mathrm{CDCl}_{3}\right): \delta(\mathrm{ppm}) 25.9,40.2,55.7,111.3(\mathrm{~m}), 113.6,114.4,115.4,115.9(\mathrm{~d}, J=23.0 \mathrm{~Hz}), 124.1$, 129.0-129.3 (m), $130.9(\mathrm{~d}, J=3.4 \mathrm{~Hz}), 138.1,140.0,142.7,153.1,161.3(\mathrm{dd}, J=250.0,7.4 \mathrm{~Hz})$, $162.3(\mathrm{~d}, J=249.2 \mathrm{~Hz})$.

3-Methoxy- $N$-methyl-aniline (15a). In a $25 \mathrm{~mL}$ flask were added 3-methoxyaniline (2.0 mmol, $0.224 \mathrm{~mL})$ and sodium methoxide $(10 \mathrm{mmol}, 545 \mathrm{mg})$ in $3.5 \mathrm{~mL}$ of anhydrous methanol. Then, paraformaldehyde (4 mmol, $119 \mathrm{mg}$ ) was diluted in $1.5 \mathrm{~mL}$ of anhydrous methanol and the solution was added to the mixture. Molecular sieves ( $4 \AA$ ) was then added and the mixture was stirred overnight at room temperature. The mixture was heated under reflux for 1 hour with sodium borohydride ( $2 \mathrm{mmol}, 75.6 \mathrm{mg})$, then sodium borohydride $(3.172 \mathrm{mmol}, 120 \mathrm{mg}$ ) was added again and reaction mixture was stirred under reflux for 3 hours. The reaction mixture was filtered on Celite, evaporated, dissolved in EtOAc and water, and the two phases were separated. The aqueous phase was then basified by addition of a saturated aqueous solution of $\mathrm{NaHCO}_{3}$, and extracted by EtOAc. The organic phase were washed with a saturated aqueous solution of $\mathrm{NaHCO}_{3}$ and brine, dried over $\mathrm{MgSO}_{4}$, evaporated and dried under reduced pressure to give the titled product as brown oil $(266 \mathrm{mg}, 96 \%)$. MS $[\mathrm{M}+\mathrm{H}]^{+} \mathrm{m} / z=138.0 .{ }^{1} \mathrm{H} \mathrm{NMR}(300 \mathrm{MHz}$, $\left.\mathrm{CDCl}_{3}\right): \delta(\mathrm{ppm}) 2.84(\mathrm{~s}, 3 \mathrm{H}), 3.78(\mathrm{~s}, 3 \mathrm{H}), 6.19(\mathrm{t}, J=2.3 \mathrm{~Hz}, 1 \mathrm{H}), 6.26-6.31(\mathrm{~m}, 2 \mathrm{H}), 7.10(\mathrm{t}, J$ $=8.1 \mathrm{~Hz}, 1 \mathrm{H})$.

tert-Butyl $N$-[2-(3-methoxy- $N$-methyl-anilino)-2-oxo-ethyl]carbamate (15b). In a $25 \mathrm{~mL}$ flask was added 3-methoxy-N-methyl-aniline (15a) (1.554 mmol, $213 \mathrm{mg})$ in $1 \mathrm{~mL}$ of EtOAc. Then 2(tert-butoxycarbonylamino)acetic acid (1.865 mmol, $326 \mathrm{mg})$, Т3Р® (2.331 mmol, $1.374 \mathrm{~mL})$ 
and DIEA (4.662 mmol, $814 \mu \mathrm{L})$ were added, and the mixture was stirred for $30 \mathrm{~min}$ at room temperature. Then the reaction mixture was diluted with EtOAc. The solution was washed with water, then with a saturated aqueous solution of $\mathrm{NaHCO}_{3}$ and brine. The organic phase was dried over $\mathrm{MgSO}_{4}$, and filtered and then evaporated and dried under reduced pressure to give a light brown solid. This residue was purified by flash chromatography using as eluent a mixture of DCM/cyclohexane (9/1) to pure DCM and then DCM/ MeOH (1000/1) to give the expected product as a yellowish powder $(444 \mathrm{mg}, 97 \%)$. MS $[\mathrm{M}+\mathrm{H}]^{+} \mathrm{m} / z=295.2$.

[2-(3-Methoxy- $N$-methyl-anilino)-2-oxo-ethyl] ammonium; 2,2,2-trifluoroacetate (15c). tertbutyl $N$-[2-(3-methoxy- $N$-methyl-anilino)-2-oxo-ethyl]carbamate (15b) (444.4 mg, $1.510 \mathrm{mmol})$ was dissolved in $4 \mathrm{~mL}$ of DCM. TFA (19.97 mmol, $1.529 \mathrm{~mL})$ was added and the reaction mixture was stirred at room temperature for 30 minutes. Solvent was removed to give a viscous reddish oil. $699 \mathrm{mg}$ of residue were obtained corresponding to the expected product and to a rest of 3-methoxy-N-methyl-aniline. Residue was used without further purification in the next step of the synthesis. MS $[\mathrm{M}+\mathrm{H}]^{+} m / z=195.1$.

$N$-(3-Methoxy-phenyl)-2-[3-(4-fluoro-phenyl)-isothioureido]- $N$-methyl-acetamide (15d). In a $100 \mathrm{~mL}$ flask were added 1-fluoro-4-isothiocyanato-benzene (1.287 mmol, $446 \mathrm{mg})$ and $\mathrm{NEt}_{3}$ (1.544 mmol, $0.208 \mathrm{~mL})$ in $2 \mathrm{~mL}$ of ethanol. A solution of [2-(3-methoxy- $N$-methyl-anilino)-2oxo-ethyl] ammonium; 2,2,2-trifluoroacetate (15c) $(1.287 \mathrm{mmol}, 446 \mathrm{mg})$ and $\mathrm{NEt}_{3}(4.254$ mmol, $0.574 \mathrm{~mL}$ ) in $20 \mathrm{~mL}$ of ethanol was added dropwise at room temperature. Reaction mixture was evaporated to dryness to give oil. This oil was purified by flash chromatography using as eluent a mixture of $\mathrm{DCM} / \mathrm{MeOH}(98 / 2)$, to give the titled product as a white solid (361 mg, $69 \%)$. MS $[\mathrm{M}+\mathrm{H}]^{+} m / z=386.0 .{ }^{1} \mathrm{H}$ NMR (300 MHz, DMSO- $\left.d_{6}\right): \delta(\mathrm{ppm}) 3.19(\mathrm{~s}, 3 \mathrm{H}), 3.78$ 
(s, 3H), 4.03 (brs, 2H), 6.92-7.04 (m, 3H), 7.09-7.21 (m, 2H), 7.30-7.50 (m, 3H), 7.68-7.79 (m, $1 \mathrm{H})$.

\section{2-[2-(2,6-Difluoro-benzyl)-3-(4-fluoro-phenyl)-isothioureido]-N-(3-methoxy-phenyl)-N-}

methyl-acetamide (15e). The titled product was obtained as an orange solid (136 mg, $94 \%$ ) following procedure B without purification, using $N$-(3-methoxy-phenyl)-2-[3-(4-fluoro-phenyl)isothioureido]- $N$-methyl-acetamide (15d) (100 mg) and 2-(bromomethyl)-1,3-difluoro-benzene $(60 \mathrm{mg}) . \mathrm{MS}[\mathrm{M}+\mathrm{H}]^{+} \mathrm{m} / z=474.1 .{ }^{1} \mathrm{H} \mathrm{NMR}\left(300 \mathrm{MHz}, \mathrm{CDCl}_{3}\right): \delta(\mathrm{ppm}) 3.32(\mathrm{~s}, 3 \mathrm{H}), 3.81(\mathrm{~s}$, 3H), 3.90 (brs, 2H), 4.13 (brs, 2H), 6.68-6.96 (m, 9H), 7.16-7.26 (m, 1H), 7.34 (t, $J=8.1 \mathrm{~Hz}$, $1 \mathrm{H})$.

[2-(2,6-Difluoro-benzylsulfanyl)-3-(4-fluoro-phenyl)-3H-imidazol-4-yl]-(3-methoxy-phenyl)methyl-amine (15). 2-[2-(2,6-Difluoro-benzyl)-3-(4-fluoro-phenyl)-isothioureido]-N-(3methoxy-phenyl)-N-methyl-acetamide (15e) $(136 \mathrm{mg}, 0.27 \mathrm{mmol})$ was dissolved in $2.7 \mathrm{~mL}$ of EtOAc. DIEA ( $283 \mu \mathrm{L}, 1.62 \mathrm{mmol})$, and T3P® in EtOAc $(477 \mu \mathrm{L}, 0.83 \mathrm{mmol})$ were then added. The mixture was heated under microwave irradiation at $150^{\circ} \mathrm{C}$ for $10 \mathrm{~min}$. DIEA $(283 \mu \mathrm{L}, 1.62$ mmol), and $\mathrm{T} 3 \mathrm{P} \circledast$ in EtOAc $(477 \mu \mathrm{L}, 0.83 \mathrm{mmol})$ were added again, and reaction mixture was heated again under microwave irradiation at $150^{\circ} \mathrm{C}$ for $10 \mathrm{~min}$. DIEA $(142 \mu \mathrm{L}, 0.81 \mathrm{mmol})$, and $\mathrm{T} 3 \mathrm{P} \circledast$ in EtOAc $(240 \mu \mathrm{L}, 0.41 \mathrm{mmol})$ were added again, and reaction mixture was heated again under microwave irradiation at $150^{\circ} \mathrm{C}$ for $10 \mathrm{~min}$. DIEA $(142 \mu \mathrm{L}, 0.81 \mathrm{mmol})$, and $\mathrm{T} 3 \mathrm{P} \circledast$ in EtOAc $(240 \mu \mathrm{L}, 0.41 \mathrm{mmol})$ were added again, and reaction mixture was heated again under microwave irradiation at $150^{\circ} \mathrm{C}$ for $10 \mathrm{~min}$. Reaction mixture was then diluted with EtOAc, washed with water, with a saturated aqueous solution of $\mathrm{NaHCO}_{3}$, and brine. Organic phase was then dried over $\mathrm{Na}_{2} \mathrm{SO}_{4}$ and evaporated. Residue was then purified by flash chromatography using as eluent a mixture of cyclohexane/EtOAc (85/15), to give the titled compound as an 
orange residue $(12.1 \mathrm{mg}, 10 \%)$. LC-MS: $\mathrm{t}_{\mathrm{R}}=3.62 \mathrm{~min}, \mathrm{MS}[\mathrm{M}+\mathrm{H}]^{+} \mathrm{m} / z=456.1$. HRMS found 456.1341; $\mathrm{C}_{24} \mathrm{H}_{20} \mathrm{~F}_{3} \mathrm{~N}_{3} \mathrm{OS}$ requires 456.1357. ${ }^{1} \mathrm{H} \mathrm{NMR}\left(300 \mathrm{MHz}, \mathrm{CDCl}_{3}\right): \delta(\mathrm{ppm}) 2.91(\mathrm{~s}, 3 \mathrm{H})$, $3.77(\mathrm{~s}, 3 \mathrm{H}), 4.19(\mathrm{~s}, 2 \mathrm{H}), 6.22(\mathrm{t}, J=2.3 \mathrm{~Hz}, 1 \mathrm{H}), 6.25(\mathrm{dd}, J=8.2,2.3 \mathrm{~Hz}, 1 \mathrm{H}), 6.37(\mathrm{dd}, J=$ 8.2, $2.3 \mathrm{~Hz}, 1 \mathrm{H}), 6.81-6.86(\mathrm{~m}, 2 \mathrm{H}), 6.94-6.99(\mathrm{~m}, 4 \mathrm{H}), 7.05(\mathrm{~s}, 1 \mathrm{H}), 7.10(\mathrm{t}, J=8.1 \mathrm{~Hz}, 1 \mathrm{H})$, 7.15-7.25 (m, 1H). ${ }^{13} \mathrm{C}$ NMR (75 MHz, $\left.\mathrm{CDCl}_{3}\right): \delta(\mathrm{ppm}) 25.8,39.4,55.2,99.9,103.5,106.3$, $111.3(\mathrm{~m}), 113.5(\mathrm{t}, J=19.3 \mathrm{~Hz}), 116.0(\mathrm{~d}, J=22.9 \mathrm{~Hz}), 125.3,129.1(\mathrm{~d}, J=8.8 \mathrm{~Hz}), 129.2(\mathrm{t}, J$ $=10.3 \mathrm{~Hz}), 129.8,130.7(\mathrm{~d}, J=3.1 \mathrm{~Hz}), 138.5,138.7,149.9,160.6,161.2(\mathrm{dd}, J=250.2,7.6 \mathrm{~Hz})$, $162.3(\mathrm{~d}, J=249.3 \mathrm{~Hz})$.

3,4-Dichloro-N-methyl-aniline (16a). In a 25mL flask were added 3,4-dichloroaniline (324 mg, $2.0 \mathrm{mmol}$ ) and sodium methoxide $(540 \mathrm{mg}, 10 \mathrm{mmol})$ in $3.5 \mathrm{~mL}$ of anhydrous methanol. Then, paraformaldehyde $(120 \mathrm{mg}, 4 \mathrm{mmol})$ was diluted in $1.5 \mathrm{~mL}$ of anhydrous methanol and the solution was added to the mixture. Molecular sieves ( $4 \AA$ ) was then added and the mixture was stirred overnight at room temperature. The mixture was then heated under reflux for 1 hour with sodium borohydride (151 mg, $4 \mathrm{mmol}$ ). Reaction mixture was then filtered on Celite, evaporated, residue was dissolved in EtOAc and water, and the two phases were separated. Aqueous phase was then basified by addition of a saturated aqueous solution of $\mathrm{NaHCO}_{3}$, and extracted by EtOAc. Organic phases were washed with a saturated aqueous solution of $\mathrm{NaHCO}_{3}$ and brine, dried over $\mathrm{MgSO}_{4}$, evaporated and dried under vacuum to give yellow oil corresponding to the titled product $(227 \mathrm{mg}, 64 \%)$. MS $[\mathrm{M}+\mathrm{H}]^{+} \mathrm{m} / z=179.9 .{ }^{1} \mathrm{H}$ NMR $\left(300 \mathrm{MHz}, \mathrm{CDCl}_{3}\right): \delta(\mathrm{ppm})$ $2,83(\mathrm{~s}, 3 \mathrm{H}), 6,48(\mathrm{dd}, J=8.7,2.8 \mathrm{~Hz}, 1 \mathrm{H}), 6,70(\mathrm{~d}, J=2.8 \mathrm{~Hz}, 1 \mathrm{H}), 7.21(\mathrm{~d}, J=8.8 \mathrm{~Hz}, 1 \mathrm{H})$.

tert-Butyl N-[2-(3,4-dichloro-N-methyl-anilino)-2-oxo-ethyl]carbamate (16b). In a $10 \mathrm{~mL}$ flask were 3,4-dichloro-N-methyl-aniline (16a) $(226 \mathrm{mg}, 1.287 \mathrm{mmol})$ in $2.6 \mathrm{~mL}$ of EtOAc. Then 2-(tert-butoxycarbonylamino)acetic acid (608 mg, $3.474 \mathrm{mmol})$, T3P® $(2.27 \mathrm{~mL}, 3.859$ 
mmol) and DIEA $(1.012 \mathrm{~mL}, 5.791 \mathrm{mmol})$ were added. The mixture was stirred at $40^{\circ} \mathrm{C}$ for 2 days. Then the reaction mixture was diluted with EtOAc, washed with water, with a saturated aqueous solution of $\mathrm{NaHCO}_{3}$ and brine. The organic phase was dried over $\mathrm{MgSO}_{4}$, and evaporated to dryness to give yellowish oil. For the next step of the synthesis, yield was considered to be $100 \%$. MS $\left[\mathrm{M}+\mathrm{H}-\mathrm{H}_{2} \mathrm{C}=\mathrm{C}\left(\mathrm{CH}_{3}\right)_{2}\right]^{+} \mathrm{m} / \mathrm{z}=277.0 .{ }^{1} \mathrm{H} \mathrm{NMR}\left(300 \mathrm{MHz}, \mathrm{CDCl}_{3}\right): \delta$ (ppm) $1.40(\mathrm{~m}, 9 \mathrm{H}), 3.25(\mathrm{~s}, 3 \mathrm{H}), 3.65(\mathrm{~s}, 2 \mathrm{H}), 3.35(\mathrm{~s}, 1 \mathrm{H}), 7.10(\mathrm{dd}, J=8.4,2.4 \mathrm{~Hz}, 1 \mathrm{H}), 3.37$ $(\mathrm{d}, J=2.3 \mathrm{~Hz}, 2 \mathrm{H}), 7.72(\mathrm{~d}, J=8.5 \mathrm{~Hz}, 1 \mathrm{H})$.

[2-(3,4-Dichloro-N-methyl-anilino)-2-oxo-ethyl] ammonium; 2,2,2-trifluoroacetate (16c). Tert-butyl N-[2-(3,4-dichloro-N-methyl-anilino)-2-oxo-ethyl]carbamate (16b) (428 mg, 1.287 mmol ) was dissolved in $4 \mathrm{~mL}$ of DCM. TFA $(1.30 \mathrm{~mL}, 17.03 \mathrm{mmol})$ was added and the reaction mixture was stirred at room temperature for 30 minutes. Solvent was removed to give oil. Residue was used without further purification in the next step of the synthesis. MS $[\mathrm{M}+\mathrm{H}]^{+} \mathrm{m} / \mathrm{z}=$ 235.1

$N$-(3,4-Dichloro-phenyl)-2-[3-(4-fluoro-phenyl)-isothioureido]- $N$-methyl-acetamide (16d). In a $100 \mathrm{~mL}$ flask were added 4-fluorophenylisothiocyanate (237 mg, $1.54 \mathrm{mmol})$ and $\mathrm{NEt}_{3}(0.208$ $\mathrm{mL}, 1.544 \mathrm{mmol})$ in $2 \mathrm{~mL}$ of ethanol. A solution of [2-(3,4-dichloro-N-methyl-anilino)-2-oxoethyl] ammonium; 2,2,2-trifluoroacetate (16c) (446 mg $1.287 \mathrm{mmol}$ ) and $\mathrm{NEt}_{3}(0.574 \mathrm{~mL}, 4.25$ $\mathrm{mmol}$ ) in $20 \mathrm{~mL}$ of ethanol was added dropwise at room temperature. Reaction mixture was then evaporated to dryness. The residue was purified by flash chromatography using as eluent a mixture of $\mathrm{DCM} / \mathrm{MeOH}(98 / 2)$, to give a white solid corresponding to the titled product (550 mg, quantitative yield). MS $[\mathrm{M}+\mathrm{H}]^{+} \mathrm{m} / z=386.0,{ }^{1} \mathrm{H}$ NMR (300 MHz, DMSO- $\left.d_{6}\right): \delta$ (ppm) 3.21 (s, 3H), 4.09 (s, 2H), 7.16 (m, 2H), 7.41-7.47 (m, 3H), 7.74-7.80 (m, 3H), $9.90(\mathrm{~s}, 1 \mathrm{H})$. 


\section{2-[2-(2,6-Difluoro-benzyl)-3-(4-fluoro-phenyl)-isothioureido]-N-(3,4-dichloro-phenyl)-N-}

methyl-acetamide (16e). The titled product was obtained as a yellowish oil (334 mg, $90 \%$ ), without purification, following Procedure B, using N-(3,4-dichloro-phenyl)-2-[3-(4-fluorophenyl)-isothioureido]- $N$-methyl-acetamide (16d) $(280 \mathrm{mg}$ ) and 2-Bromomethyl-1,3-difluorobenzene $(150 \mathrm{mg}) . \mathrm{MS}[\mathrm{M}+\mathrm{H}]^{+} \mathrm{m} / z=512.1 .{ }^{1} \mathrm{H} \mathrm{NMR}\left(300 \mathrm{MHz}, \mathrm{CDCl}_{3}\right): \delta(\mathrm{ppm}) 3.31(\mathrm{~s}, 3 \mathrm{H})$, $3.92(\mathrm{~s}, 2 \mathrm{H}), 4.12(\mathrm{~s}, 2 \mathrm{H}), 6.75-6.98(\mathrm{~m}, 6 \mathrm{H}), 7.13(\mathrm{~m}, 1 \mathrm{H}), 7.23(\mathrm{~m}, 1 \mathrm{H}), 7.38(\mathrm{~m}, 1 \mathrm{H}), 7.53(\mathrm{~d}$, $J=8.5 \mathrm{~Hz}, 1 \mathrm{H})$.

\section{[2-(2,6-Difluoro-benzylsulfanyl)-3-(4-fluoro-phenyl)-3H-imidazol-4-yl]-(3,4-dichloro-}

phenyl)-methyl-amine (16). The titled product was obtained as an orange powder (143 mg, 44\%), following Procedure C, using 2-[2-(2,6-Difluoro-benzyl)-3-(4-fluoro-phenyl)isothioureido]-N-(3,4-dichloro-phenyl)-N-methyl-acetamide (16e) $(334 \mathrm{mg})$. LC-MS: $\mathrm{t}_{\mathrm{R}}=3.97$ $\min$; MS $[\mathrm{M}+\mathrm{H}]^{+} \mathrm{m} / z=496.0$. HRMS found 494.0457; $\mathrm{C}_{23} \mathrm{H}_{16}{ }^{35} \mathrm{Cl}_{2} \mathrm{~F}_{3} \mathrm{~N}_{3} \mathrm{~S}$ requires 494.0472. ${ }^{1} \mathrm{H}$ NMR $\left(\mathrm{CDCl}_{3}\right): \delta(\mathrm{ppm}) 2,92(\mathrm{~s}, 3 \mathrm{H}), 4,19(\mathrm{~s}, 2 \mathrm{H}), 6,45(\mathrm{dd}, J=8.9,3.1 \mathrm{~Hz}, 1 \mathrm{H}), 6,72(\mathrm{~d}, J=3.0$ $\mathrm{Hz}, 1 \mathrm{H}), 6,87(\mathrm{t}, J=7.7 \mathrm{~Hz}, 1 \mathrm{H}), 6,82-6,95(\mathrm{~m}, 6 \mathrm{H}), 7,05(\mathrm{~s}, 1 \mathrm{H}), 7,2(\mathrm{~d}, J=2.6 \mathrm{~Hz}, 1 \mathrm{H}), 7,22$ $(\mathrm{d}, J=2.6 \mathrm{~Hz}, 1 \mathrm{H}) .{ }^{13} \mathrm{C} \mathrm{NMR}\left(75 \mathrm{MHz}, \mathrm{CDCl}_{3}\right): \delta(\mathrm{ppm}) 25.8,39.6,111.4(\mathrm{~m}), 112.5,113.5(\mathrm{t}$, $J=19.4 \mathrm{~Hz}), 114.5,116.3(\mathrm{~d}, J=23.1 \mathrm{~Hz}), 121.7,125.6,129.0(\mathrm{~d}, J=8.8 \mathrm{~Hz}), 129.3(\mathrm{t}, J=10.3$ Hz), 130.4, 132.9, 137.4, 139.5, 148.0, $161.2(\mathrm{dd}, J=250.0,7.3 \mathrm{~Hz}), 162.5(\mathrm{~d}, J=249.9 \mathrm{~Hz})$.

2-Chloro-N-[(3,4-dimethoxyphenyl)methyl]-N-methylacetamide (17b). In a 100mL flask was introduced commercial [(3,4-dimethoxyphenyl)methyl](methyl)amine (17a) $\quad(1.05 \mathrm{~mL}, 5.3$ mmol) and DIEA (2.74 mL, $15.89 \mathrm{mmol})$ in $13 \mathrm{~mL}$ of DCM (dried over $\mathrm{Na}_{2} \mathrm{SO}_{4}$ ). The solution was stirred at $0^{\circ} \mathrm{C}$. Then, chloroacetyl chloride $(0.84 \mathrm{~mL}, 10.59 \mathrm{mmol})$ in $13 \mathrm{~mL}$ of DCM (dried over $\mathrm{Na}_{2} \mathrm{SO}_{4}$ ) was added dropwise in the flask. The mixture was then evaporated to dryness to 
give a brown residue. Conversion was considered to be $100 \%$ for the next reaction. MS $[\mathrm{M}+\mathrm{H}]^{+}$ $m / z=257.9$.

[(3,4-Dimethoxy-benzyl)-methyl-carbamoyl]-methyl-ammonium formate (17c). 2-chloro-N[(3,4-dimethoxyphenyl)methyl]-N-methylacetamide (17b) was dissolved in $9 \mathrm{~mL}$ of Ethanol $95^{\circ} \mathrm{C}$ and added dropwise in a $250 \mathrm{~mL}$ flask containing $100 \mathrm{~mL}$ of aqueous ammonia at $65^{\circ} \mathrm{C}$. After the addition, heating was stopped. The mixture was evaporated to dryness. The residue was then dissolved in DCM, and extracted several times by an aqueous solution of $\mathrm{HCOOH} 1 \mathrm{M}$. During this extraction, a precipitate appeared and was filtered. The filtrate was then evaporated to dryness, and the residue was triturated in acetonitrile. The supernatant was evaporated to dryness, to give the titled product as a pale brown oily residue $\left(90 \% \mathrm{UV}_{215 \mathrm{~nm}}\right.$ purity) $(1.51 \mathrm{~g}$, 90\%). MS $[\mathrm{M}+\mathrm{H}]^{+} \mathrm{m} / \mathrm{z}=239.0$.

N-(3,4-Dimethoxy-benzyl)-2-[3-(4-fluoro-phenyl)-thioureido]-N-methyl-acetamide (17d). $732 \mathrm{mg}$ of 4 -fluorophenylisothiocyanate and $774 \mu \mathrm{L}$ of $\mathrm{NEt}_{3}$ were added in a $250 \mathrm{~mL}$ flask in 4 $\mathrm{mL}$ Ethanol. [(3,4-dimethoxy-benzyl)-methyl-carbamoyl]-methyl-ammonium formate $(\mathbf{1 7 c})$ (1.51 g, $4.78 \mathrm{mmol}$ ) was dissolved in $60 \mathrm{~mL}$ of ethanol and $645 \mu \mathrm{L}$ of $\mathrm{NEt}_{3}$ were then added. This solution was added dropwise at room temperature. After the addition, the reaction was over. Reaction mixture was evaporated to dryness, and purified by flash chromatography using as eluent a mixture of cyclohexane/EtOAc (6/4) to give the titled product as a yellowish solid (880 $\mathrm{mg}, 47 \%$ yield $) . \mathrm{MS}[\mathrm{M}+\mathrm{H}]^{+} \mathrm{m} / z=391.9 .{ }^{1} \mathrm{H}$ NMR $\left(300 \mathrm{MHz}, \mathrm{MeOD}-d_{4}\right): \delta(\mathrm{ppm}) 2.91-2.99$ (m, 3H), 3.81-3.84 (m, 6H), 4.47-4.58 (m, 4H), 6.81-6.98 (m, 3H), 7.08-7.15 (m, 2H), 7.39-7.45 $(\mathrm{m}, 2 \mathrm{H})$.

2-[2-(2,6-Difluoro-benzyl)-3-(4-fluoro-phenyl)-isothioureido]-N-(3,4-dimethoxy-benzyl)-Nmethyl-acetamide (17e). The titled product was obtained as an oily residue (207 $\mathrm{mg}, 58 \%$ ), 
following Procedure B, using N-(3,4-Dimethoxy-benzyl)-2-[3-(4-fluoro-phenyl)-thioureido]-Nmethyl-acetamide (17d) (0,300 g) and 2-Bromomethyl-1,3-difluoro-benzene (77 mg). MS $[\mathrm{M}+\mathrm{H}]^{+} \mathrm{m} / z=518.0 .{ }^{1} \mathrm{H}$ NMR $\left(300 \mathrm{MHz}, \mathrm{DMSO}-d_{6}\right): \delta(\mathrm{ppm}) 2.85(\mathrm{~m}, 3 \mathrm{H}), 3.65(\mathrm{~m}, 3 \mathrm{H}), 3.70$ (s, 3H), $4.15(\mathrm{~m}, 2 \mathrm{H}), 4.23(\mathrm{~m}, 2 \mathrm{H}), 4.47(\mathrm{~m}, 2 \mathrm{H}), 6.64(\mathrm{~m}, 2 \mathrm{H}), 6.77-6.89(\mathrm{~m}, 4 \mathrm{H}), 6.99(\mathrm{~m}$, 2H), $7.09(\mathrm{~m}, 2 \mathrm{H}), 7.39(\mathrm{~m}, 1 \mathrm{H})$.

\section{[2-(2,6-Difluoro-benzylsulfanyl)-3-(4-fluoro-phenyl)-3H-imidazol-4-yl]-(3,4-dimethoxy-}

benzyl)-methyl-amine (17). The titled product was obtained as a yellowish powder (91 mg, 47 \%) following procedure C using 2-[2-(2,6-Difluoro-benzyl)-3-(4-fluoro-phenyl)-isothioureido]$\mathrm{N}$-(3,4-dimethoxy-benzyl)-N-methyl-acetamide (17e) $(200 \mathrm{mg})$. LC-MS: $\mathrm{t}_{\mathrm{R}}=3.33 \mathrm{~min}, \mathrm{MS}$ : $[\mathrm{M}+\mathrm{H}]^{+} m / z=499.9$. HRMS found 500.1622; $\mathrm{C}_{26} \mathrm{H}_{24} \mathrm{~F}_{3} \mathrm{~N}_{3} \mathrm{O}_{2} \mathrm{~S}$ requires 500.1620. ${ }^{1} \mathrm{H}$ NMR (300 $\left.\mathrm{MHz}, \mathrm{CDCl}_{3}\right): \delta(\mathrm{ppm}) 2.48(\mathrm{~s}, 3 \mathrm{H}), 3.68(\mathrm{~s}, 2 \mathrm{H}), 3.77(\mathrm{~s}, 3 \mathrm{H}), 3.86(\mathrm{~s}, 3 \mathrm{H}), 4.10(\mathrm{~s}, 2 \mathrm{H}), 6.37(\mathrm{~d}$, $J=1.9 \mathrm{~Hz}, 1 \mathrm{H}), 6.56(\mathrm{dd}, J=8.2,1.9 \mathrm{~Hz}, 1 \mathrm{H}), 6.74(\mathrm{~d}, J=8.1 \mathrm{~Hz}, 1 \mathrm{H}), 6.77-6.85(\mathrm{~m}, 3 \mathrm{H}), 7.10-$ $7.22(\mathrm{~m}, 5 \mathrm{H}) .{ }^{13} \mathrm{C} \mathrm{NMR}\left(75 \mathrm{MHz}, \mathrm{CDCl}_{3}\right): \delta(\mathrm{ppm})$ 26.0, 40.4, 55.8, 55.9, 60.6, 110.6, 111.1, $111.3,113.5(\mathrm{t}, J=19.0 \mathrm{~Hz}), 116.0(\mathrm{~d}, J=22.1 \mathrm{~Hz}), 117.6,121.0,129.1(\mathrm{t}, J=10.1 \mathrm{~Hz}), 129.7$, $129.9(\mathrm{~d}, J=8.5 \mathrm{~Hz}), 131.6(\mathrm{~d}, J=2.3 \mathrm{~Hz}), 136.4,145.8,148.3,148.8,161.2(\mathrm{dd}, J=250.0,7.7$ $\mathrm{Hz}), 162.3(\mathrm{~d}, J=248.9 \mathrm{~Hz})$.

N-Allyl-3,4-dimethoxy-aniline (18a). Allyl bromide (0.519 mL, $6.0 \mathrm{mmol})$ was added dropwise to a solution of 3,4-dimethoxyaniline $(919 \mathrm{mg}, 6.0 \mathrm{mmol})$ and $\mathrm{K}_{2} \mathrm{CO}_{3}(1.99 \mathrm{~g}, 14.4 \mathrm{mmol})$ in DMF (15 mL). The solution was heated to $80{ }^{\circ} \mathrm{C}$ and stirred at this temperature overnight. The reaction mixture was then filtered, washed with $\mathrm{H}_{2} \mathrm{O}$ and extracted with EtOAc. The combined organic extracts were washed with brine, dried over $\mathrm{Na}_{2} \mathrm{SO}_{4}$ and evaporated to dryness. Residue was purified by flash chromatography using as eluent a mixture of cyclohexane/EtOAc (8/2) to give the titled product as a pale yellowish oil $(587 \mathrm{mg}, 51 \%)$. MS $[\mathrm{M}+\mathrm{H}]^{+} \mathrm{m} / \mathrm{z}=194.0 .{ }^{1} \mathrm{H} \mathrm{NMR}$ 
$\left(300 \mathrm{MHz}, \mathrm{CDCl}_{3}\right): \delta(\mathrm{ppm}) 3.74(\mathrm{Dt}, J=5.5,1.5 \mathrm{~Hz}, 2 \mathrm{H}), 3.81(\mathrm{~s}, 3 \mathrm{H}), 3.84(\mathrm{~s}, 3 \mathrm{H}), 5.17$ (Dq, $J$ $=10.3,1.5 \mathrm{~Hz}, 1 \mathrm{H}), 5.29(\mathrm{Dq}, J=17.2,1.6 \mathrm{~Hz}, 1 \mathrm{H}), 5.98(\mathrm{Ddt}, J=17.2,10.6,5.3 \mathrm{~Hz}, 1 \mathrm{H}), 6.18$ $(\mathrm{dd}, J=8.5,2.6 \mathrm{~Hz}, 1 \mathrm{H}), 6.29(\mathrm{~d}, J=2.6 \mathrm{~Hz}, 1 \mathrm{H}), 6.75(\mathrm{~d}, J=8.5 \mathrm{~Hz}, 1 \mathrm{H})$.

tert-Butyl N-[2-(N-allyl-3,4-dimethoxy-anilino)-2-oxo-ethyl]carbamate (18b). In a 100mL flask were added N-allyl-3,4-dimethoxy-aniline (18a) $(587.0 \mathrm{mg}, 3.04 \mathrm{mmol}), 6 \mathrm{~mL}$ of EtOAc, Boc-Gly-OH (638.6 mg, $3.65 \mathrm{mmol})$, T3P® (2.69 mL, $4.56 \mathrm{mmol})$, and DIEA (1.59 mL, 9.11 mmol). Reaction mixture was then stirred at room temperature for 2 hours. The reaction mixture was diluted with EtOAc, washed with a saturated aqueous solution of $\mathrm{NaHCO}_{3}$ and brine, and the organic phase was dried over $\mathrm{Na}_{2} \mathrm{SO}_{4}$ and evaporated to give the titled product as yellowish viscous oil $(1.07 \mathrm{~g}, 100 \%)$. MS $[\mathrm{M}+\mathrm{H}]^{+} \mathrm{m} / z=351.1 .{ }^{1} \mathrm{H} \mathrm{NMR}\left(300 \mathrm{MHz}, \mathrm{CDCl}_{3}\right): \delta(\mathrm{ppm}) 1.41$ (s, 9H), $3.66(\mathrm{~d}, J=4.2 \mathrm{~Hz}, 2 \mathrm{H}), 3.85(\mathrm{~s}, 3 \mathrm{H}), 3.88(\mathrm{~s}, 3 \mathrm{H}), 4.26(\mathrm{~d}, J=6.4 \mathrm{~Hz}, 2 \mathrm{H}), 5.04-5.19$ (m, 2H), 5.39 (brs, 1H), $5.85(\mathrm{Ddt}, J=16.8,10.3,6.5 \mathrm{~Hz}, 1 \mathrm{H}), 6.64(\mathrm{~d}, J=2.2 \mathrm{~Hz}, 1 \mathrm{H}), 6.72$ $(\mathrm{dd}, J=8.4,2.4 \mathrm{~Hz}, 1 \mathrm{H}), 6.83(\mathrm{~d}, J=8.4 \mathrm{~Hz}, 1 \mathrm{H})$.

[2-(N-Allyl-3,4-dimethoxy-anilino)-2-oxo-ethyl]ammonium;2,2,2-trifluoroacetate

(18c). Tert-butyl N-[2-(N-allyl-3,4-dimethoxy-anilino)-2-oxo-ethyl]carbamate (18b) (1.07 g, 3.05 mmol) was dissolved in $7 \mathrm{~mL}$ of DCM. $3 \mathrm{~mL}$ of TFA were then gently added and reaction mixture was then stirred at room temperature for $30 \mathrm{~min}$. Reaction mixture was then evaporated to dryness, to give pale orange oil, corresponding to the titled product. This oil will enter in the next step without further purification. Yield was considered to be $100 \%$. MS $[\mathrm{M}+\mathrm{H}]^{+} \mathrm{m} / \mathrm{z}=$ 251.1.

N-Allyl-N-(3,4-dimethoxy-phenyl)-2-[3-(4-fluoro-phenyl)-isothioureido]-acetamide (18d). 4fluorophenylisothiocyanate (468 mg, $3.05 \mathrm{mmol})$ and $\mathrm{NEt}_{3}(494 \mu \mathrm{L}, 3.66 \mathrm{mmol})$ were added in a $250 \mathrm{~mL}$ flask in $9 \mathrm{~mL}$ Ethanol. [2-(N-allyl-3,4-dimethoxy-anilino)-2-oxo- 
ethyl]ammonium;2,2,2-trifluoroacetate $(\mathbf{1 8 c})(3.05 \mathrm{mmol})$ was dissolved in $31 \mathrm{~mL}$ of ethanol, $\mathrm{NEt}_{3}$ was added until $\mathrm{pH}$ was over 8 and the mixture was added dropwise at room temperature. After the addition, the reaction was over. After one hour stirring a room temperature, a precipitate has appeared. It was then filtered, to give a white powder of the powder corresponding to the titled product $(1.09 \mathrm{~g}, 88 \%)$. MS $[\mathrm{M}+\mathrm{H}]^{+} \mathrm{m} / \mathrm{z}=404.1 .{ }^{1} \mathrm{H} \mathrm{NMR}(300 \mathrm{MHz}$, DMSO- $\left.d_{6}\right): \delta(\mathrm{ppm}) 3.75(\mathrm{~s}, 3 \mathrm{H}), 3.78(\mathrm{~s}, 3 \mathrm{H}), 4.01(\mathrm{~d}, J=4.4 \mathrm{~Hz}, 2 \mathrm{H}), 4.23(\mathrm{~d}, J=5.8 \mathrm{~Hz}, 2 \mathrm{H})$, 5.01-5.20 (m, 2H), 5.80 (Ddt, $J=16.0,11.5,5.7 \mathrm{~Hz}, 1 \mathrm{H}), 6.87(\mathrm{dd}, J=7.3,1.1 \mathrm{~Hz}, 1 \mathrm{H}), 6.93-$ 7.05 (m, 2H), 7.09-7.21 (m, 2H), 7.38-7.51 (m, 2H), 7.74 (brs, 1H), 9.89 (s, 1H).

\section{N-Allyl-2-[2-(2,6-difluoro-benzyl)-3-(4-fluoro-phenyl)-isothioureido]-N-(3,4-dimethoxy-}

phenyl)-acetamide (18e). In a 25mL flask were added N-Allyl-N-(3,4-dimethoxy-phenyl)-2-[3(4-fluoro-phenyl)-isothioureido]-acetamide (18d) (400 mg, $0.99 \mathrm{mmol}), \mathrm{K}_{2} \mathrm{CO}_{3}$ (137 mg, 0.99 mmol), sodium iodide (74 mg, $0.50 \mathrm{mmol}$ ), and $5 \mathrm{~mL}$ of acetonitrile. The suspension was stirred at room temperature for $10 \mathrm{~min}$, and 2-(bromomethyl)-1,3-difluoro-benzene (205 $\mathrm{mg}, 0.99$ mmol) was then added. The suspension was stirred at room temperature overnight. The medium was then evaporated, residue was dissolved in EtOAc, washed with water and brine, organic phase was dried over $\mathrm{Na}_{2} \mathrm{SO}_{4}$ and evaporated to dryness to give $543 \mathrm{mg}$ of an orange solid corresponding to the titled product $(100 \%)$. MS $[\mathrm{M}+\mathrm{H}]^{+} \mathrm{m} / z=530.2 .{ }^{1} \mathrm{H} \mathrm{NMR}(300 \mathrm{MHz}$, $\left.\mathrm{CDCl}_{3}\right): \delta(\mathrm{ppm}) 3.81-3.92(\mathrm{~m}, 8 \mathrm{H}), 4.13(\mathrm{brs}, 2 \mathrm{H}), 4.29(\mathrm{~d}, J=6.3 \mathrm{~Hz}, 2 \mathrm{H}), 5.07-5.21(\mathrm{~m}, 2 \mathrm{H})$, 5.78-5.96 (m, 1H), 6.63-6.95 (m, 10H), $7.21(\mathrm{~m}, 1 \mathrm{H})$.

\section{Allyl-[2-(2,6-difluoro-benzylsulfanyl)-3-(4-fluoro-phenyl)-3H-imidazol-4-yl]-(3,4-}

dimethoxy-phenyl)-amine (18). In a microwave tube were introduced N-Allyl-2-[2-(2,6difluoro-benzyl)-3-(4-fluoro-phenyl)-isothioureido]-N-(3,4-dimethoxy-phenyl)-acetamide (18e) (373 mg, $0.7 \mathrm{mmol}), 7 \mathrm{~mL}$ of EtOAc, DIEA (738 $\mu \mathrm{L}, 4.2 \mathrm{~mol})$, and T3P® (1245 $\mu \mathrm{L}, 2.1 \mathrm{mmol})$. 
The mixture was heated under microwave irradiation at $150^{\circ} \mathrm{C}$ for $10 \mathrm{~min}$. Reaction mixture was then diluted with EtOAc, washed with water, with a saturated aqueous solution of $\mathrm{NaHCO}_{3}$, and with brine. Organic phase was then dried over $\mathrm{Na}_{2} \mathrm{SO}_{4}$ and evaporated. Residue was then purified by flash chromatography using as eluent a mixture of $\mathrm{CHCl}_{3} / \mathrm{MeOH}(99 / 1)$ to give an orange solid corresponding to the titled product (192 mg, $53 \%)$. LC-MS: $\mathrm{t}_{\mathrm{R}}=3.27 \mathrm{~min}$, MS $[\mathrm{M}+\mathrm{H}]^{+} m / z=512.1$. HRMS found 512.1617; $\mathrm{C}_{27} \mathrm{H}_{24} \mathrm{~F}_{3} \mathrm{~N}_{3} \mathrm{O}_{2} \mathrm{~S}$ requires 512.1620. ${ }^{1} \mathrm{H}$ NMR (300 $\left.\mathrm{MHz}, \mathrm{CDCl}_{3}\right): \delta(\mathrm{ppm}) 3.75-3.86(\mathrm{~m}, 8 \mathrm{H}), 4.15(\mathrm{~s}, 2 \mathrm{H}), 5.2-5.14(\mathrm{~m}, 2 \mathrm{H}), 5.67(\mathrm{Ddt}, J=17.4$, 10.0, $5.5 \mathrm{~Hz}, 1 \mathrm{H}), 6.17(\mathrm{dd}, J=8.7,2.8 \mathrm{~Hz}, 1 \mathrm{H}), 6.30(\mathrm{~d}, J=2.8 \mathrm{~Hz}, 1 \mathrm{H}), 6.69(\mathrm{~d}, J=8.8 \mathrm{~Hz}$, 1H), 6.74-6.86 (m, 2H), 6.88-6.98 (m, 4H), $7.04(\mathrm{~s}, 1 \mathrm{H}), 7.18(\mathrm{tt}, J=8.4,6.5 \mathrm{~Hz}, 1 \mathrm{H}) .{ }^{13} \mathrm{C} \mathrm{NMR}$ (75 MHz, $\left.\mathrm{CDCl}_{3}\right): \delta(\mathrm{ppm})$ 25.9, 55.3, 55.9, 56.4, 100.7, 106.6, 111.0-111.5 (m), 112.2, $113.6(\mathrm{t}$, $J=19.3 \mathrm{~Hz}), 115.8(\mathrm{~d}, J=22.9 \mathrm{~Hz}), 117.3,125.5,129.2(\mathrm{t}, J=10.8 \mathrm{~Hz}), 129.4(\mathrm{~d}, J=8.9 \mathrm{~Hz})$, $130.8(\mathrm{~d}, J=3.2 \mathrm{~Hz}), 133.6,138.4,142.4,142.7,149.5,161.2(\mathrm{dd}, J=250.0,7.6 \mathrm{~Hz}), 162.3(\mathrm{~d}, J$ $=249.2 \mathrm{~Hz})$.

1-Cyanomethyl-3-(4-fluoro-phenyl)-isothiourea (19a). 2-aminoacetonitrile hydrochloride (725 $\mathrm{mg}, 7.83 \mathrm{mmol})$ and $\mathrm{NEt}_{3}(1090 \mu \mathrm{L}, 7.83 \mathrm{mmol})$ were added in $12 \mathrm{~mL}$ of DMF. Then a solution of 4-fluoro-phenylisothiocyanate $(1.00 \mathrm{~g}, 6.53 \mathrm{mmol})$ in $2 \mathrm{~mL}$ of DMF was added and the reaction mixture was stirred at room temperature for $5 \mathrm{~min}$, then cooled down to $0^{\circ} \mathrm{C}$. After addition of roughly $60 \mathrm{~mL}$ water, a precipitate was obtained. The mixture was stirred at $0^{\circ} \mathrm{C}$ for $30 \mathrm{~min}$ and filtrated. The purple crystals obtained correspond to the titled product $(1.09 \mathrm{~g}, 80 \%)$. MS $[\mathrm{M}+\mathrm{H}]^{+} \mathrm{m} / z=209.9 .{ }^{1} \mathrm{H}$ NMR $\left(300 \mathrm{MHz}, \mathrm{DMSO}-d_{6}\right): \delta(\mathrm{ppm}) 4.49(\mathrm{~d}, J=5.5 \mathrm{~Hz}, 2 \mathrm{H}), 7.20$ (t, $J=8.7 \mathrm{~Hz}, 2 \mathrm{H}), 7.38(\mathrm{Dd}, J=8.6,5.0 \mathrm{~Hz}, 2 \mathrm{H}), 8.03$ (brs, 1H), $10.02(\mathrm{~s}, 1 \mathrm{H})$.

2-(2,6-Difluoro-benzylsulfanyl)-3-(4-fluoro-phenyl)-3H-imidazol-4-ylamine (19b). In a 50 mL flask were added 1-Cyanomethyl-3-(4-fluoro-phenyl)-isothiourea (19a) (1.09 g, $5.21 \mathrm{mmol}$ ), 
$10 \mathrm{~mL}$ of dry acetonitrile, sodium iodide (390 mg, $2.60 \mathrm{mmol}$ ), 2-Bromomethyl-1,3-difluorobenzene $(1.08 \mathrm{~g})$ and DIEA $(891 \mu \mathrm{L}, 5.21 \mathrm{mmol})$. Reaction mixture was stirred at room temperature for 5 min. Reaction mixture was then diluted with EtOAc, washed with water and brine, dried over $\mathrm{Na}_{2} \mathrm{SO}_{4}$ and evaporated. All attempts to purify that compound were unsuccessful, due to its instability. Next step of the synthesis was performed on the crude residue. $\mathrm{MS}[\mathrm{M}+\mathrm{H}]^{+} m / z=335.9$.

\section{N-[2-(2,6-Difluoro-benzylsulfanyl)-3-(4-fluoro-phenyl)-3H-imidazol-4-yl]-3,4-dimethoxy-}

benzamide (19). 3,4-dimethoxybenzoic acid (130 mg, $0.72 \mathrm{mmol}$ ) was dissolved in $752 \mu \mathrm{L}$ of a mixture of thionyl chloride and DCM (2/8, V/V). After one hour stirring at room temperature, it was evaporated. Then 2-(2,6-Difluoro-benzylsulfanyl)-3-(4-fluoro-phenyl)-3H-imidazol-4ylamine (19b) (200 mg, $0.36 \mathrm{mmol})$ in $1.8 \mathrm{~mL}$ dry THF and Pyridine $(57.9 \mu \mathrm{L}, 0.72 \mathrm{mmol})$ were added over the residue, and the mixture was stirred at room temperature for $4 \mathrm{~h}$. Reaction mixture was then evaporated, dissolved in EtOAc, washed with water, with a saturated aqueous solution of $\mathrm{NaHCO}_{3}$ and brine. Organic phase was dried over $\mathrm{Na}_{2} \mathrm{SO}_{4}$ and evaporated. Residue was purified by flash chromatography using as eluent a mixture of cyclohexane/ EtOAc (7/3) and then $\mathrm{DCM} / \mathrm{MeOH}(98 / 2)$ to give a reddish solid corresponding to the pure titled product (56 mg, 31\%). LC-MS: $\mathrm{t}_{\mathrm{R}}=2.80 \mathrm{~min}$, MS $[\mathrm{M}+\mathrm{H}]^{+} \mathrm{m} / z=499.8$. HRMS found 500.1256; $\mathrm{C}_{25} \mathrm{H}_{20} \mathrm{~F}_{3} \mathrm{~N}_{3} \mathrm{O}_{3} \mathrm{~S}$ requires 500.1256. ${ }^{1} \mathrm{H} \mathrm{NMR}\left(300 \mathrm{MHz}, \mathrm{CDCl}_{3}\right): \delta(\mathrm{ppm}) 3.87(\mathrm{~s}, 3 \mathrm{H}), 3.89(\mathrm{~s}, 3 \mathrm{H}), 4.13(\mathrm{~s}, 2 \mathrm{H})$, 6.75-6.87 (m, 3H), 7.05-7.26 (m, 7H), $7.37(\mathrm{~d}, J=2.0 \mathrm{~Hz}, 1 \mathrm{H}), 8.15(\mathrm{~s}, 1 \mathrm{H}) .{ }^{13} \mathrm{C}$ NMR $(75 \mathrm{MHz}$, $\left.\mathrm{CDCl}_{3}\right): \delta(\mathrm{ppm}) 26.0,56.1,110.4,110.9,111.2-111.6(\mathrm{~m}), 113.2(\mathrm{t}, J=19.2 \mathrm{~Hz}), 116.6(\mathrm{~d}, J=$ $23.0 \mathrm{~Hz}), 120.1,123.4,125.5,129.3,129.5(\mathrm{t}, J=10.2 \mathrm{~Hz}), 129.7(\mathrm{~d}, J=8.8 \mathrm{~Hz}), 130.1(\mathrm{~d}, J=$ $3.3 \mathrm{~Hz}), 138.7,149.2,152.6,161.3(\mathrm{dd}, J=254.5,3.7 \mathrm{~Hz}), 162.9(\mathrm{~d}, J=250.5 \mathrm{~Hz}), 165.9$. 


\section{2-[2-(4-Bromo-2,6-difluoro-benzyl)-3-(4-fluoro-phenyl)-isothioureido]-N-(3,4-dimethoxy-}

phenyl)-N-methyl-acetamide (20a). (4-Bromo-2,6-difluoro-phenyl)-methanol (892 mg) and $\mathrm{NEt}_{3}(594 \mu \mathrm{L})$ were dissolved in dry $\mathrm{DCM}$ at $0^{\circ} \mathrm{C}$. Mesylchloride $(310 \mu \mathrm{L})$ was then added dropwise, and the mixture was stirred at room temperature overnight. Water was then added to quench the reaction. Organic phase was washed with water and brine, dried over $\mathrm{Na}_{2} \mathrm{SO}_{4}$ and evaporated to give an orange oil corresponding to 5-bromo-2-(chloromethyl)-1,3-difluorobenzene. ${ }^{1} \mathrm{H}$ NMR (300 MHz, $\left.\left.\mathrm{CDCl}_{3}\right): \delta(\mathrm{ppm}) 4.62(\mathrm{~s}, 2 \mathrm{H}), 7.14(\mathrm{~d}, J=6.7 \mathrm{~Hz} ; 2 \mathrm{H})\right)$. The titled product was then obtained as a yellowish powder $(1.07 \mathrm{~g}, 95 \%)$ following procedure B using $\mathrm{N}$ (3,4-Dimethoxy-phenyl)-2-[3-(4-fluoro-phenyl)-isothioureido]-N-methyl-acetamide (3d) (750 $\mathrm{mg}$ ), and 5-bromo-2-(chloromethyl)-1,3-difluoro-benzene (461 mg). MS $[\mathrm{M}+\mathrm{H}]^{+} \mathrm{m} / \mathrm{z}=583.8$. ${ }^{1} \mathrm{H}$ NMR (300 MHz, DMSO-d6): $\delta$ (ppm) 3.15 (s, 3H), 3.73 (m, 8H), 4.14 (s, 2H), 6.60 (m, 2H), 6.79 (brs, 1H), $6.86(\mathrm{~m}, 1 \mathrm{H}), 6.97(\mathrm{~m}, 4 \mathrm{H}), 7.46(\mathrm{~m}, 2 \mathrm{H})$.

\section{[2-(4-Bromo-2,6-difluoro-benzylsulfanyl)-3-(4-fluoro-phenyl)-3H-imidazol-4-yl]-(3,4-}

dimethoxy-phenyl)-methyl-amine (20b). The titled product was obtained as an orange oil (867 mg, $74 \%$ ) following procedure D using 2-[2-(4-Bromo-2,6-difluoro-benzyl)-3-(4-fluorophenyl)-isothioureido]-N-(3,4-dimethoxy-phenyl)-N-methyl-acetamide (20a) (1.07 g). MS $[\mathrm{M}+\mathrm{H}]^{+} m / z=565.9 .{ }^{1} \mathrm{H}$ NMR $\left(300 \mathrm{MHz}, \mathrm{DMSO}-d_{6}\right): \delta(\mathrm{ppm}) 2.91(\mathrm{~s}, 3 \mathrm{H}), 3.64-3.65(\mathrm{~m}, 6 \mathrm{H})$, $3.97(\mathrm{~s}, 2 \mathrm{H}), 6.04(\mathrm{dd}, J=8.6,2.6 \mathrm{~Hz}, 1 \mathrm{H}), 6.20(\mathrm{~d}, J=2.8 \mathrm{~Hz}, 1 \mathrm{H}), 6.76(\mathrm{~d}, J=8.7 \mathrm{~Hz}, 1 \mathrm{H})$, $6.96(\mathrm{~s}, 1 \mathrm{H}), 7.11(\mathrm{dd}, J=9.0,5.1 \mathrm{~Hz}, 2 \mathrm{H}), 7.19(\mathrm{~m}, 2 \mathrm{H}), 7.41(\mathrm{~m}, 2 \mathrm{H})$.

(3,4-Dimethoxy-phenyl)-[2-[4-(3-dimethylamino-prop-1-ynyl)-2,6-difluoro-benzylsulfanyl]3-(4-fluoro-phenyl)-3H-imidazol-4-yl]-methyl-amine (20). In a 25 mL flask, [2-(4-Bromo-2,6difluoro-benzylsulfanyl)-3-(4-fluoro-phenyl)-3H-imidazol-4-yl]-(3,4-dimethoxy-phenyl)-methylamine (20b) (600 mg, $1.06 \mathrm{mmol})$, dimethylpropargylamine (172 $\mu \mathrm{L}, 1.60 \mathrm{mmol})$, pyrrolidine 
$(133 \mu \mathrm{L}, 1.60 \mathrm{mmol})$ were added in $5 \mathrm{~mL}$ of dry and degassed DMF. Then, $\mathrm{PdCl}_{2}(\mathrm{dppf})_{2}(68 \mathrm{mg}$, $53 \mu \mathrm{mol})$ and $\mathrm{CuI}(20 \mathrm{mg}, 106 \mu \mathrm{mol})$ are added. Reaction mixture was heated under argon at $80^{\circ} \mathrm{C}$ for $6 \mathrm{~h}$. Reaction mixture was cooled down to room temperature, diluted with EtOAc, washed with brine, dried over $\mathrm{Na}_{2} \mathrm{SO}_{4}$ and evaporated. Crude product was purified by flash chromatography using as eluent a mixture of DCM/cyclohexane and then DCM/MeOH, to give $281 \mathrm{mg}$ of a white powder $(47 \%)$. LC-MS: $\mathrm{t}_{\mathrm{R}}=2.82 \mathrm{~min}, \mathrm{MS}[\mathrm{M}+\mathrm{H}]^{+} \mathrm{m} / z=566.9$. HRMS found 567.2054; $\mathrm{C}_{30} \mathrm{H}_{29} \mathrm{~F}_{3} \mathrm{~N}_{4} \mathrm{O}_{2} \mathrm{~S}$ requires 567.2042. ${ }^{1} \mathrm{H}$ NMR (300 MHz, $\mathrm{CDCl}_{3}$ ): $\delta$ (ppm) 2.35 (s, 6H), $2.91(\mathrm{~s}, 3 \mathrm{H}), 3.45(\mathrm{~s}, 2 \mathrm{H}), 3.79(\mathrm{~s}, 3 \mathrm{H}), 3.82(\mathrm{~s}, 3 \mathrm{H}), 4.08(\mathrm{~s}, 2 \mathrm{H}), 6.15(\mathrm{dd}, J=8.7,2.7$ $\mathrm{Hz}, 1 \mathrm{H}), 6.28(\mathrm{~d}, J=2.7 \mathrm{~Hz}, 1 \mathrm{H}), 6.72(\mathrm{~d}, J=8.7 \mathrm{~Hz}, 1 \mathrm{H}), 6.87(\mathrm{~d}, J=8.0 \mathrm{~Hz}, 2 \mathrm{H}), 6.97(\mathrm{~m}$, 4H), $7.02(\mathrm{~s}, 1 \mathrm{H})$.

\section{(3-\{4-[5-[(3,4-Dimethoxy-phenyl)-methyl-amino]-1-(4-fluoro-phenyl)-1H-imidazol-2-}

ylsulfanylmethyl]-3,5-difluoro-phenyl\}-prop-2-ynyl)-trimethyl-ammonium iodide (21). In a $25 \mathrm{~mL}$ flask were added (3,4-Dimethoxy-phenyl)-[2-[4-(3-dimethylamino-prop-1-ynyl)-2,6difluoro-benzylsulfanyl]-3-(4-fluoro-phenyl)-3H-imidazol-4-yl]-methyl-amine (20) (254 mg, $448 \mu \mathrm{mol})$, and $5 \mathrm{~mL}$ of a mixture dry $\mathrm{Et}_{2} \mathrm{O} / \mathrm{dry}_{\mathrm{THF}}(1: 1)$. Iodomethane $(27.7 \mu \mathrm{L}, 1.345 \mathrm{mmol})$ was then added, and reaction mixture was stirred at room temperature. After $1 \mathrm{~h} 30$ and $4 \mathrm{~h}$, iodomethane $(27.7 \mu \mathrm{L}, 1.345 \mathrm{mmol})$ was added again. Reaction mixture was then evaporated to dryness. Residue was triturated in $\mathrm{Et}_{2} \mathrm{O}$, filtrated, and the residue was purified by preparative HPLC (ammonium formate buffer, $\mathrm{pH}$ 3.8) to give the titled product as a brown residue (55 mg, 17\%). LC-MS: $\mathrm{t}_{\mathrm{R}}=2.83 \mathrm{~min}$, MS $[\mathrm{M}]^{+} \mathrm{m} / \mathrm{z}=581.1$. HRMS found 581.2212; $\mathrm{C}_{31} \mathrm{H}_{32} \mathrm{~F}_{3} \mathrm{~N}_{4} \mathrm{O}_{2} \mathrm{~S}$ requires 581.2198. ${ }^{1} \mathrm{H}$ NMR (300 MHz, DMSO-d6): $\delta(\mathrm{ppm}) 2.92(\mathrm{~s}, 3 \mathrm{H}), 3.21(\mathrm{~s}, 9 \mathrm{H}), 3.64(\mathrm{~s}$, $3 \mathrm{H}), 3.65(\mathrm{~s}, 3 \mathrm{H}), 4.01(\mathrm{~s}, 2 \mathrm{H}), 4.68(\mathrm{~s}, 2 \mathrm{H}), 6.06(\mathrm{dd}, J=8.8,2.8 \mathrm{~Hz}, 1 \mathrm{H}), 6.21(\mathrm{~d}, J=2.7 \mathrm{~Hz}$,

$1 \mathrm{H}), 6.75(\mathrm{~d}, J=8.8 \mathrm{~Hz}, 1 \mathrm{H}), 6.95(\mathrm{~s}, 1 \mathrm{H}), 7.13-7.25(\mathrm{~m}, 4 \mathrm{H}), 7.40(\mathrm{~m}, 2 \mathrm{H}) .{ }^{13} \mathrm{C} \mathrm{NMR}(75 \mathrm{MHz}$, 
DMSO-d6): $\delta$ (ppm) 26.2, 52.7, 52.9, 55.9, 56.7, 80.7, 88.1, 100.1, 105.6; 113.8, 115.6, 116.3, $116.5,122.0,124.4,130.2,131.5,136.5,140.4,142.6,143.4,149.8,160.6,162.2$.

\section{(3-\{4-[5-[(3,4-Dimethoxy-phenyl)-methyl-amino]-1-(4-fluoro-phenyl)-1H-imidazol-2-} ylsulfanylmethyl]-3,5-difluoro-phenyl\}-prop-2-ynyl)-trimethyl-ammonium formate (22). (3,4-Dimethoxy-phenyl)-[2-[4-(3-dimethylamino-prop-1-ynyl)-2,6-difluoro-benzylsulfanyl]-3(4-fluoro-phenyl)-3H-imidazol-4-yl]-methyl-amine (20) (365 mg, $644 \mu \mathrm{mol}$ ) was dissolved in $6.4 \mathrm{~mL}$ of a mixture of dry $\mathrm{Et}_{2} \mathrm{O} / \mathrm{THF}(1 / 1)$, under argon, and iodomethane ( $80 \mu \mathrm{L}, 1.29 \mathrm{mmol}$ ) was then added. Reaction mixture was stirred at room temperature. After $1 \mathrm{~h} 30$ iodomethane (80 $\mu \mathrm{L}, 1.29 \mathrm{mmol}$ ) was added again. After $30 \mathrm{~min}$, reaction mixture was evaporated to dryness. Residue was then purified twice by preparative HPLC (HCOOH $0.1 \%$ first, then ammonium formate buffer, $\mathrm{pH}$ 9.2) to give the titled product as a yellowish powder ( $75 \mathrm{mg}, 19 \%)$. LC-MS: $\mathrm{t}_{\mathrm{R}}=2.83 \mathrm{~min}, \mathrm{MS}[\mathrm{M}]^{+} \mathrm{m} / z=581.1$. HRMS found 581.2213; $\mathrm{C}_{31} \mathrm{H}_{32} \mathrm{~F}_{3} \mathrm{~N}_{4} \mathrm{O}_{2} \mathrm{~S}$ requires 581.2198. ${ }^{1} \mathrm{H}$ NMR (300 MHz, CDCl 3 ): $\delta(\mathrm{ppm}) 2.94$ (s, 3H), 3.45 (s, 9H), 3.78-3.80 (m, 6H), 4.01 (s, 2H), $4.87(\mathrm{~s}, 2 \mathrm{H}), 6.16(\mathrm{dd}, J=8.7,2.7 \mathrm{~Hz}, 1 \mathrm{H}), 6.27(\mathrm{~d}, J=2.7 \mathrm{~Hz}, 1 \mathrm{H}), 6.71(\mathrm{~d}, J=8.7 \mathrm{~Hz}, 1 \mathrm{H})$, 6.96-7.07 (m, 7H), $8.58(\mathrm{~s}, 1 \mathrm{H}) .{ }^{13} \mathrm{C} \mathrm{NMR}\left(75 \mathrm{MHz}, \mathrm{CDCl}_{3}\right): \delta$ (ppm) 25.9, 40.5, 53.4, 56.0, 56.6, 57.1, 89.6, 100.4, 106.0, 112.6, $115.5(\mathrm{~d}, J=26.8 \mathrm{~Hz}), 116.2(\mathrm{~d}, J=23.0 \mathrm{~Hz}), 116.8(\mathrm{t}, J=$ 19.2 Hz), $121.4(\mathrm{t}, J=12.5 \mathrm{~Hz}), 124.3,129.4(\mathrm{~d}, J=8.7 \mathrm{~Hz}), 131.0(\mathrm{~d}, J=3.2 \mathrm{~Hz}), 137.3,140.4$, 143.0, 143.2, 149.7, $160.9(\mathrm{dd}, J=251.9,9.1 \mathrm{~Hz}), 162.5(\mathrm{~d}, J=250.3 \mathrm{~Hz}), 167.5$.

2,6-Difluoro-4-hydroxy-benzoic acid. 2,6-Difluoro-4-hydroxy-benzonitrile $\left(\begin{array}{ll}1.5 & \mathrm{~g}\end{array}\right)$ was dissolved in $7 \mathrm{~mL}$ distilled water and a solution of $1,35 \mathrm{~g}$ of $\mathrm{NaOH}$ in $4 \mathrm{~mL}$ water was then added. Reaction mixture was then heated at reflux for 4 days. Heating was then stopped, and reaction mixture was acidified by adding concentrated $\mathrm{HCl}$, and extracted with $\mathrm{Et}_{2} \mathrm{O}$. Organic phase was then extracted by a saturated aqueous solution of $\mathrm{NaHCO}_{3}$. This aqueous solution was 
then acidified by adding concentrated $\mathrm{HCl}$, and then extracted by $\mathrm{Et}_{2} \mathrm{O}$. Organic phase was dried over $\mathrm{Na}_{2} \mathrm{SO}_{4}$, and evaporated, to give the titled product as a white solid (1.58 g, $\left.94 \%\right)$. MS [M$\mathrm{H}]^{-} m / z=172.9 .{ }^{1} \mathrm{H}$ NMR $\left(300 \mathrm{MHz}, \mathrm{DMSO}-d_{6}\right): \delta(\mathrm{ppm}) 6.49(\mathrm{~m}, 2 \mathrm{H}), 10.96(\mathrm{brs}, 1 \mathrm{H}), 13.20$ (brs, $1 \mathrm{H})$.

2,6-Difluoro-4-hydroxy-benzoic acid methyl ester. 2,6-difluoro-4-hydroxy-benzoic acid (1.58 g) was dissolved in $18 \mathrm{~mL}$ of methanol, concentrated sulphuric acid $(257 \mu \mathrm{L})$ was then added and reaction mixture was heated at reflux overnight. Reaction mixture was then evaporated, and residue was dissolved in EtOAc, washed twice with water, brine, and dried over $\mathrm{Na}_{2} \mathrm{SO}_{4}$ and evaporated to give the titled product as a white powder $(1.48 \mathrm{~g}, 90 \%)$. MS $[\mathrm{M}-\mathrm{H}]^{-} \mathrm{m} / \mathrm{z}=187.1$. ${ }^{1} \mathrm{H}$ NMR (300 MHz, DMSO-d $)$ ): $\delta(\mathrm{ppm}) 3.80(\mathrm{~s}, 3 \mathrm{H}), 6.54(\mathrm{~m}, 2 \mathrm{H}), 11.12(\mathrm{~s}, 1 \mathrm{H})$.

3,5-Difluoro-4-hydroxymethyl-phenol (23i). In a $100 \mathrm{~mL}$ flask were added 2,6-Difluoro-4hydroxy-benzoic acid methyl ester $(1.48 \mathrm{~g}), 26 \mathrm{~mL}$ anhydrous $\mathrm{THF}$, and $34 \mathrm{~mL}$ of a $1 \mathrm{M}$ solution of diisobutylaluminum hydride (DIBAl-H) in cyclohexane at $0-5^{\circ} \mathrm{C}$. Reaction mixture was then stirred at this temperature for $1.5 \mathrm{~h}$, and then poured into a $250 \mathrm{~mL}$ flask containing $27 \mathrm{~mL}$ of cold $\left(0-5^{\circ} \mathrm{C}\right) 1 \mathrm{M}$ aqueous potassium sodium L-tartrate solution. Reaction mixture was stirred at room temperature for $30 \mathrm{~min}$. Aqueous phase was extracted by EtOAc, and combined organic phases were then washed with brine, dried over $\mathrm{Na}_{2} \mathrm{SO}_{4}$, and evaporated. Aqueous phase was acidified to $\mathrm{pH} 5$, and extracted by EtOAc. Organic phase was dried over $\mathrm{Na}_{2} \mathrm{SO}_{4}$ and evaporated. The titled product was obtained as a yellowish powders $(1 \mathrm{~g}, 80 \%)$. MS $[\mathrm{M}-\mathrm{H}]^{-} \mathrm{m} / \mathrm{z}=$ 159.0. ${ }^{1} \mathrm{H}$ NMR $\left(300 \mathrm{MHz}, \mathrm{DMSO}-d_{6}\right): \delta(\mathrm{ppm}) 4.36(\mathrm{~d}, J=5.2 \mathrm{~Hz}, 2 \mathrm{H}), 5.00(\mathrm{t}, J=5.5 \mathrm{~Hz}$, 1H), $6.41(\mathrm{~m}, 2 \mathrm{H}), 10.28(\mathrm{~s}, 1 \mathrm{H})$.

[4-(3-Chloropropoxy)-2,6-difluoro-phenyl]methanol. 1-bromo-3-chloro-propane $(1.30 \mathrm{~mL}$, $13.2 \mathrm{mmol})$, 3,5-Difluoro-4-hydroxymethyl-phenol (23i) (2.64 mmol, $423 \mathrm{mg})$ and $\mathrm{K}_{2} \mathrm{CO}_{3}(365$ 
$\mathrm{mg}, 2.64 \mathrm{mmol})$ were added in acetonitrile $(9 \mathrm{~mL})$ and the reaction mixture was stirred at reflux for 3 hours. The solvent was removed under reduced pressure. The crude was dissolved in EtOAc and washed with water. The aqueous phase was extracted by EtOAc, washed with brine and dried over $\mathrm{Na}_{2} \mathrm{SO}_{4}$. The solvents were removed under reduced pressure, to give the titled product as colorless oil $(602 \mathrm{mg}, 96 \%)$. MS $\left[\mathrm{M}+\mathrm{H}-\mathrm{H}_{2} \mathrm{O}\right]^{+} \mathrm{m} / z=218.9 .{ }^{1} \mathrm{H}$ NMR $(300 \mathrm{MHz}$, $\left.\mathrm{CDCl}_{3}\right): \delta(\mathrm{ppm}) 2.24($ quin, $J=6.1 \mathrm{~Hz}, 2 \mathrm{H}), 3.73(\mathrm{t}, J=6.3 \mathrm{~Hz}, 2 \mathrm{H}), 4.10(\mathrm{t}, J=5.8 \mathrm{~Hz}, 2 \mathrm{H})$, $4.71(\mathrm{~s}, 2 \mathrm{H}), 6.41-6.52(\mathrm{~m}, 2 \mathrm{H})$.

2-Chloromethyl-5-(3-chloro-propoxy)-1,3-difluoro-benzene (23ii). [4-(3-chloropropoxy)-2,6difluoro-phenyl]methanol (602 mg, $2.54 \mathrm{mmol})$ and $\mathrm{NEt}_{3}(428 \mu \mathrm{L}, 3.17 \mathrm{mmol})$ were dissolved in $5 \mathrm{~mL}$ dry $\mathrm{DCM}$ at $0^{\circ} \mathrm{C}$. Mesylchloride $(197 \mu \mathrm{L}, 2.54 \mathrm{mmol})$ was then added dropwise, and the mixture was stirred at room temperature overnight. Reaction mixture was then evaporated to dryness. Water was added to quench the reaction. The organic phase was then washed with water and brine, and dried over $\mathrm{Na}_{2} \mathrm{SO}_{4}$, and then evaporated. The obtained residue corresponding to the titled product would enter in the next step of the synthesis without further purification.

2-[2-[2,6-Difluoro-4-(3-chloropropoxy)-benzyl]-3-(4-fluoro-phenyl)-isothioureido]-N-(3,4dimethoxy-phenyl)-N-methyl-acetamide (23a). The titled product was obtained as a yellowish solid (915 mg, $73 \%$ ), following Procedure B, using N-(3,4-Dimethoxy-benzyl)-2-[3-(4-fluorophenyl)-thioureido]-N-methyl-acetamide (3d) (800 mg) and 2-Chloromethyl-5-(3-chloropropoxy)-1,3-difluoro-benzene (23ii). MS $[\mathrm{M}+\mathrm{H}]^{+} \mathrm{m} / \mathrm{z}=595.9 .{ }^{1} \mathrm{H} \mathrm{NMR}\left(300 \mathrm{MHz}, \mathrm{CDCl}_{3}\right): \delta$ (ppm) 2.15 (quin, $J=5.9 \mathrm{~Hz}, 2 \mathrm{H}), 3.27(\mathrm{~s}, 3 \mathrm{H}), 3.66(\mathrm{t}, J=6.2 \mathrm{~Hz}, 2 \mathrm{H}), 3.76-3.93(\mathrm{~m}, 8 \mathrm{H}), 3.95-$ $4.14(\mathrm{~m}, 4 \mathrm{H}), 6.32-6.46(\mathrm{~m}, 2 \mathrm{H}), 6.60-6.94(\mathrm{~m}, 7 \mathrm{H})$.

[2-(2,6-Difluoro-4-(3-chloropropoxy)-benzylsulfanyl)-3-(4-fluoro-phenyl)-3H-imidazol-4yl]-(3,4-dimethoxy-phenyl)-methyl-amine (23b). The titled product was obtained as a brown 
solid (895 mg, 96\%), following Procedure D (without Flash Chromatography purification), using 2-[2-[2,6-Difluoro-4-(3-chloropropoxy)-benzyl]-3-(4-fluoro-phenyl)-isothioureido]-N-(3,4dimethoxy-phenyl)-N-methyl-acetamide (23a) $(915 \mathrm{mg}) . \mathrm{MS}[\mathrm{M}+\mathrm{H}]^{+} \mathrm{m} / z=577.9 .{ }^{1} \mathrm{H} \mathrm{NMR}$ $\left(300 \mathrm{MHz}, \mathrm{CDCl}_{3}\right): \delta(\mathrm{ppm}) 2.21$ (quin, $\left.J=6.0 \mathrm{~Hz}, 2 \mathrm{H}\right), 2.91(\mathrm{~s}, 3 \mathrm{H}), 3.72(\mathrm{t}, J=6.2 \mathrm{~Hz}, 2 \mathrm{H})$, 3.77-3.86 (m, 6H), 4.00-4.14 (m, 4H), $6.16(\mathrm{dd}, J=8.7,2.8 \mathrm{~Hz}, 1 \mathrm{H}), 6.30(\mathrm{~d}, J=2.7 \mathrm{~Hz}, 1 \mathrm{H})$, 6.32-6.42 (m, 2H), $6.72(\mathrm{~d}, J=8.7 \mathrm{~Hz}, 1 \mathrm{H}), 6.91-7.05(\mathrm{~m}, 5 \mathrm{H}) .{ }^{13} \mathrm{C} \mathrm{NMR}\left(75 \mathrm{MHz}, \mathrm{CDCl}_{3}\right): \delta$ (ppm) 25.8, 31.8, 40.1, 41.1, 55.9, 56.4, 64.8, 98.0-98.6 (m), 100.0, 105.5, $105.6(\mathrm{t}, J=20.2 \mathrm{~Hz})$, 112.4, $115.9(\mathrm{~d}, J=22.9 \mathrm{~Hz}), 124.3,129.2(\mathrm{~d}, J=8.7 \mathrm{~Hz}), 130.9(\mathrm{~d}, J=3.1 \mathrm{~Hz}), 138.5,139.5$, 142.7, 143.2, 149.6, $159.5(\mathrm{t}, J=14.1 \mathrm{~Hz}), 161.7(\mathrm{dd}, J=248.1,11.0 \mathrm{~Hz}), 162.3(\mathrm{~d}, J=249.2$ $\mathrm{Hz})$.

\section{2-[[4-[3-(1-Aza-4-azoniabicyclo[2.2.2]octan-4-yl)propoxy]-2,6-difluoro-} phenyl]methylsulfanyl]-N-(3,4-dimethoxyphenyl)-3-(4-fluorophenyl)-N-methyl-imidazol-4amine ; formate (23). [2-(2,6-Difluoro-4-(3-chloropropoxy)-benzylsulfanyl)-3-(4-fluorophenyl)-3H-imidazol-4-yl]-(3,4-dimethoxy-phenyl)-methyl-amine (23b) (225 mg, $370 \mu \mathrm{mol})$ and 1,4-diazabicyclo[2.2.2]octane (DABCO) $(112 \mathrm{mg}, 1.0 \mathrm{mmol})$ were dissolved in dry acetonitrile (3.7 mL). Reaction mixture was then heated under microwave irradiation at $100{ }^{\circ} \mathrm{C}$ for $30 \mathrm{~min}$. It was then evaporated to dryness and purified by preparative HPLC (ammonium formate buffer, $\mathrm{pH}=9.2)$ to give the titled compound as a pale orange powder $(60 \mathrm{mg}, 23 \%)$. LC-MS: $\mathrm{t}_{\mathrm{R}}=2.47$ $\min ; \mathrm{MS}[\mathrm{M}]^{+} \mathrm{m} / \mathrm{z}=654.2$. HRMS found 654.2733; $\mathrm{C}_{34} \mathrm{H}_{39} \mathrm{~F}_{3} \mathrm{~N}_{5} \mathrm{O}_{3} \mathrm{~S}$ requires 654.2726. ${ }^{1} \mathrm{H}$ NMR (300 MHz, $\mathrm{CDCl}_{3}$ ): $\delta$ (ppm) 2.31 (brs, 2H), 2.94 (s, 3H), 3.32 (brs, 6H), 3.48-3.82 (m, 14H), $3.94(\mathrm{~s}, 2 \mathrm{H}), 4.06$ (brs, 2H), $6.16(\mathrm{dd}, J=8.7,2.7 \mathrm{~Hz}, 1 \mathrm{H}), 6.27(\mathrm{~d}, J=2.7 \mathrm{~Hz}, 1 \mathrm{H}), 6.35-6.47$ $(\mathrm{m}, 2 \mathrm{H}), 6.71(\mathrm{~d}, J=8.8 \mathrm{~Hz}, 1 \mathrm{H}), 6.93-7.11(\mathrm{~m}, 5 \mathrm{H}), 8.60(\mathrm{~s}, 1 \mathrm{H}) .{ }^{13} \mathrm{C} \mathrm{NMR}\left(75 \mathrm{MHz}, \mathrm{CDCl}_{3}\right)$ : $\delta(\mathrm{ppm}) 22.1,25.7,40.3,45.3,52.6,55.9,56.5,61.8,65.2,98.2-98.8(\mathrm{~m}), 100.1,105.9,106.0(\mathrm{t}$, 
$J=20.1 \mathrm{~Hz}), 112.5,116.0(\mathrm{~d}, J=22.9 \mathrm{~Hz}), 123.9,129.3(\mathrm{~d}, J=8.8 \mathrm{~Hz}), 130.9(\mathrm{~d}, J=3.2 \mathrm{~Hz})$, 137.8, 140.1, 142.8, 143.1, 149.6, $159.0(\mathrm{t}, J=14.1 \mathrm{~Hz}), 161.6(\mathrm{dd}, J=248.2,11.0 \mathrm{~Hz}), 162.3$ $(\mathrm{d}, J=249.3 \mathrm{~Hz})$.

\section{3-[4-[[5-(3,4-Dimethoxy-N-methyl-anilino)-1-(4-fluorophenyl)imidazol-2-}

yl]sulfanylmethyl]-3,5-difluoro-phenoxy]propane-1-sulfonate; ammonium (24). In a 2-5 mL microwave tube, [2-(2,6-Difluoro-4-(3-chloropropoxy)-benzylsulfanyl)-3-(4-fluoro-phenyl)-3Himidazol-4-yl]-(3,4-dimethoxy-phenyl)-methyl-amine (23b) (540 mg, $0.89 \mathrm{mmol})$ was dissolved in $6 \mathrm{~mL}$ of a mixture of dioxane and water (1/1, V/V). Sodium sulfite $(559 \mathrm{mg}, 4.44 \mathrm{mmol})$ and sodium iodide (133 $\mathrm{mg}, 0.89 \mathrm{mmol}$ ) were then added. Reaction mixture was heated under microwave irradiation at $130^{\circ} \mathrm{C}$ for $30 \mathrm{~min}$ and then at $130^{\circ} \mathrm{C}$ for $40 \mathrm{~min}$. Then Sodium sulfite (223 mg, $1.8 \mathrm{mmol})$ and sodium iodide $(53 \mathrm{mg}, 0.36 \mathrm{mmol})$ were added again, before heating under microwave irradiation at $130{ }^{\circ} \mathrm{C}$ for $30 \mathrm{~min}$. Reaction mixture was evaporated to dryness and purified by preparative HPLC (ammonium formate buffer $\mathrm{pH}=3.8$ ) to give the titled product a yellowish powder $(207 \mathrm{mg}, 36 \%)$. LC-MS: $\mathrm{t}_{\mathrm{R}}=2.40 \mathrm{~min}, \mathrm{MS}[\mathrm{M}]^{-} \mathrm{m} / z=622.1$. HRMS found 624.1453; $\mathrm{C}_{28} \mathrm{H}_{27} \mathrm{~F}_{3} \mathrm{~N}_{3} \mathrm{O}_{6} \mathrm{~S}_{2}$ requires 624.1450. ${ }^{1} \mathrm{H} \mathrm{NMR}\left(300 \mathrm{MHz}, \mathrm{MeOD}-d_{4}\right): \delta$ (ppm) 2.18-2.30 (m, 2H), 2.92-3.02 (m, 5H), $3.73(\mathrm{~s}, 3 \mathrm{H}), 3.75(\mathrm{~s}, 3 \mathrm{H}), 3.93(\mathrm{~s}, 2 \mathrm{H}), 4.11(\mathrm{t}, J=$ $6.3 \mathrm{~Hz}, 2 \mathrm{H}), 6.16(\mathrm{dd}, J=8.7,2.8 \mathrm{~Hz}, 1 \mathrm{H}), 6.30(\mathrm{~d}, J=2.7 \mathrm{~Hz}, 1 \mathrm{H}), 6.48-6.58(\mathrm{~m}, 2 \mathrm{H}), 6.78(\mathrm{~d}$, $J=8.7 \mathrm{~Hz}, 1 \mathrm{H}), 6.89-6.98(\mathrm{~m}, 2 \mathrm{H}), 6.99-7.11(\mathrm{~m}, 3 \mathrm{H}) .{ }^{13} \mathrm{C} \mathrm{NMR}\left(75 \mathrm{MHz}, \mathrm{MeOD}-d_{4}\right): \delta(\mathrm{ppm})$ 24.6, 26.6, 39.8, 47.7, 55.2, 55.8, 67.2, 98.0-98.3 (m), 101.7, $105.3(\mathrm{t}, J=20.0 \mathrm{~Hz}), 107.6,113.1$, 115.3, (d , $J=23.4 \mathrm{~Hz}), 121.4,129.7(\mathrm{~d}, J=9.0 \mathrm{~Hz}), 130.6(\mathrm{~d}, J=3.1 \mathrm{~Hz}), 137.3,141.1,142.9$, 143.5, 149.8, $160.2(\mathrm{t}, J=14.3 \mathrm{~Hz}), 161.5(\mathrm{dd}, J=246.6,11.2 \mathrm{~Hz}), 162.6(\mathrm{~d}, J=248.3 \mathrm{~Hz})$.

[4-(3-Bromopropoxy)-2,6-difluoro-phenyl]methanol (25i). 1,3-dibromopropane (950.87 $\mu \mathrm{L}$, $9.37 \mathrm{mmol}$ ), 3,5-difluoro-4-(hydroxymethyl)phenol (300 mg, $1.87 \mathrm{mmol}$ ) and $\mathrm{K}_{2} \mathrm{CO}_{3}(258.95$ 
$\mathrm{mg}, 1.87 \mathrm{mmol})$ were added in acetonitrile $(6 \mathrm{~mL})$ and the reaction mixture was stirred at reflux for 3 hours. The solvent was removed under reduced pressure. The crude was dissolved in EtOAc and washed with water. The aqueous phase was extracted with EtOAc and washed with brine, dried under $\mathrm{Na}_{2} \mathrm{SO}_{4}$. The solvents were removed under reduced pressure, and the crude was purified by flash chromatography using as eluent a mixture of Cy/EA (80/20) to give 400 mg of [4-(3-bromopropoxy)-2,6-difluoro-phenyl]methanol as a colorless oil, leading to a 76\% yield. MS $[\mathrm{M}+\mathrm{H}]^{+} m / z=264$.

tert-Butyl N-tert-butoxycarbonyl-N-[3-[3,5-difluoro-4-(hydroxymethyl)-phenoxy]propyl]carbamate (25ii). [4-(3-bromopropoxy)-2,6-difluoro-phenyl]methanol 25i (320 mg, $1.14 \mathrm{mmol}$ ) was dissolved in $11 \mathrm{~mL}$ of dry dimethylformamide. tert-butyl $\mathrm{N}$-tert-butoxycarbonylcarbamate (247.33 $\mathrm{mg}, 1.14 \mathrm{mmol})$ and cesium carbonate $(370.91 \mathrm{mg}, 1.14 \mathrm{mmol})$ were added and the reaction mixture was stirred at $70^{\circ} \mathrm{C}$ for $30 \mathrm{~min}$. The solvent was removed. The crude was dissolved in EtOAc, washed with water, dried over $\mathrm{Na}_{2} \mathrm{SO}_{4}$. The solvent was removed. The crude was purified by flash chromatography using as eluent a mixture of $\mathrm{Cy} / \mathrm{EA}(90 / 10)$ to give $500 \quad \mathrm{mg} \quad$ of $\quad$ tert-butyl N-tert-butoxycarbonyl-N-[3-[3,5-difluoro-4(hydroxymethyl)phenoxy]propyl]carbamate as a colorless oil, leading to a $95 \%$ yield. MS $[\mathrm{M}+\mathrm{H}]^{+} \mathrm{m} / \mathrm{z}=344 .{ }^{1} \mathrm{H}$ NMR $(300 \mathrm{MHz}, \mathrm{DMSO}-d 6): \delta(\mathrm{ppm}) 1.41(\mathrm{~s}, 18 \mathrm{H}), 1.87-1.96(\mathrm{q}, J=$ 12.6, 6.1 Hz, 2H), $3.64(\mathrm{t}, J=6.9 \mathrm{~Hz}, 2 \mathrm{H}), 3.99(\mathrm{t}, J=5.7 \mathrm{~Hz}, 2 \mathrm{H}), 4.39(\mathrm{~d}, J=5.7 \mathrm{~Hz}, 2 \mathrm{H}), 5.08$ (t, $J=5.4 \mathrm{~Hz}, 2 \mathrm{H}), 6.59-6.68(\mathrm{~m}, 2 \mathrm{H})$.

tert-Butyl

phenoxy]propyl]carbamate (25iii). Tert-butyl N-tert-butoxycarbonyl-N-[3-[3,5-difluoro-4(hydroxymethyl)phenoxy]propyl]-carbamate $25 \mathrm{ii}(520 \mathrm{mg}, 1.25 \mathrm{mmol})$ and $\mathrm{NEt}_{3}(420.17 \mu \mathrm{L}$, $3.11 \mathrm{mmol})$ were dissolved in dry dichloromehtane at $0^{\circ} \mathrm{C}$. Mesylchloride $(144.91 \mu \mathrm{L}, 1.87$ 
mmol) was then added dropwise, and the mixture was stirred at room temperature overnight. Water was then added to quench the reaction. The organic phase was then washed with water and brine, and dried over $\mathrm{Na}_{2} \mathrm{SO}_{4}$, and then evaporated to give $475 \mathrm{mg}$ of the titled compound as colorless oil, leading to a $87 \%$ yield. It will be used without further purification in the next step of the synthesis. MS $[\mathrm{M}+\mathrm{H}]^{+} m / z=453.0$.

tert-Butyl N-tert-butoxycarbonyl-N-[3-[4-[[(Z)-N-[2-(3,4-dimethoxy-N-methyl-anilino)-2oxo-ethyl]-N'-(4-fluorophenyl)carbamimidoyl]sulfanylmethyl]-3,5-difluoro-

phenoxy]propyl]carbamate (25a). In a $50 \mathrm{~mL}$ flask were added $\mathrm{N}$-(3,4-dimethoxyphenyl)-2[[(Z)-N-(4-fluorophenyl)-C-sulfanyl-carbonimidoyl]amino]-N-methyl-acetamide $\quad(411.3 \quad \mathrm{mg}$, $1.09 \mathrm{mmol})$, DIEA (206.57 $\mu \mathrm{L}, 1.2 \mathrm{mmol})$, and $2.5 \mathrm{~mL}$ of acetonitrile. The suspension was stirred at room temperature for $10 \mathrm{~min}$, and residue from tert-butyl N-tert-butoxycarbonyl-N-[3[4-(chloromethyl)-3,5-difluoro-phenoxy]propyl]carbamate (25iii) $(475 \mathrm{mg}, 1.09 \mathrm{mmol})$ in $3 \mathrm{~mL}$ of acetonitrile was then added. The suspension was stirred at room temperature overnight. The solvent was then evaporated, residue was dissolved in EtOAc, washed with water and brine, organic phase was dried over $\mathrm{Na}_{2} \mathrm{SO}_{4}$ and evaporated. Residue was then purified by flash chromatography using as eluent a mixture of cyclohexane/EtOAc (6/4) to give $300 \mathrm{mg}(35 \%)$ of 25a as yellowish oil. MS $[\mathrm{M}+\mathrm{H}]^{+} \mathrm{m} / z=777 .{ }^{1} \mathrm{H}$ NMR (300 MHz, DMSO-d6): $\delta(\mathrm{ppm}) 1.37(\mathrm{~s}$, $18 \mathrm{H}), 1.89$ (t, $J=6.4 \mathrm{~Hz}, 2 \mathrm{H}), 3.16(\mathrm{~s}, 3 \mathrm{H}), 3.61(\mathrm{t}, J=7.0 \mathrm{~Hz}, 2 \mathrm{H}), 3.68(\mathrm{~s}, 3 \mathrm{H}), 3.71-3.74(\mathrm{~m}$, 2H), $3.76(\mathrm{~s}, 3 \mathrm{H}), 3.98(\mathrm{t}, J=5.4 \mathrm{~Hz}, 2 \mathrm{H}), 4.10(\mathrm{~s}, 2 \mathrm{H}), 6.58-6.63(\mathrm{~m}, 2 \mathrm{H}), 6.66(\mathrm{~d}, J=9.6 \mathrm{~Hz}$, $2 \mathrm{H}), 6.88(\mathrm{~d}, J=8.3 \mathrm{~Hz}, 2 \mathrm{H}), 6.90-7.01(\mathrm{~m}, 4 \mathrm{H})$.

tert-Butyl N-tert-butoxycarbonyl-N-[3-[4-[[5-(3,4-dimethoxy-N-methyl-anilino)-1-(4fluorophenyl)imidazol-2-yl]sulfanylmethyl]-3,5-difluoro-phenoxy]propyl]carbamate (25b). In $100 \mathrm{~mL}$ flask were introduced tert-butyl N-tert-butoxycarbonyl-N-[3-[4-[[(Z)-N-[2-(3,4- 
dimethoxy-N-methyl-anilino)-2-oxo-ethyl]-N'-(4-fluorophenyl)carbamimidoyl]sulfanylmethyl]3,5-difluoro-phenoxy]propyl]carbamate (300 mg, 0,39 mmol), $4 \mathrm{~mL}$ of EtOAc, DIEA (0.4 mL, $2.32 \mathrm{mmol})$, and $\mathrm{T} 3 \mathrm{P} \AA(0.68 \mathrm{~mL}, 1.16 \mathrm{mmol})$. The mixture was heated at reflux for $7 \mathrm{~h}$. After 7 hours, DIEA $(0.4 \mathrm{~mL}, 2.32 \mathrm{mmol})$ and T3P® $(0.68 \mathrm{~mL}, 1.16 \mathrm{mmol})$ were added again. After 24 hours, DIEA $(0.4 \mathrm{~mL}, 2.32 \mathrm{mmol})$, and T3P® $(0.68 \mathrm{~mL}, 1.16 \mathrm{mmol})$ were added again. After 48 hours, the reaction was over and the reaction mixture was diluted in EtOAc. The solution was then washed with a saturated aqueous solution of $\mathrm{NaHCO}_{3}$, and with brine. Organic phase was dried over $\mathrm{Na}_{2} \mathrm{SO}_{4}$ and evaporated to dryness. Residue was purified by flash chromatography using as eluent a mixture of $\mathrm{DCM} / \mathrm{MeOH}(99 / 1)$ to give $183 \mathrm{mg}$ of the titled compound as orange oil, leading to a $62 \%$ yield. MS $[\mathrm{M}+\mathrm{H}]^{+} \mathrm{m} / z=759 .{ }^{1} \mathrm{H}$ NMR (300 MHz, DMSO$d 6): \delta(\mathrm{ppm}) 1.40(\mathrm{~s}, 18 \mathrm{H}), 1.91(\mathrm{t}, J=6.3 \mathrm{~Hz}, 2 \mathrm{H}), 2.92(\mathrm{~s}, 3 \mathrm{H}), 3.63(\mathrm{~s}, 3 \mathrm{H}), 3.64(\mathrm{~s}, 3 \mathrm{H}), 3.63$ $(\mathrm{t}, J=6.3 \mathrm{~Hz}, 2 \mathrm{H}), 3.98(\mathrm{t}, J=5.5 \mathrm{~Hz}, 2 \mathrm{H}), 3.98(\mathrm{~s}, 2 \mathrm{H}), 6.03-6.07(\mathrm{dd}, J=8.7,2.8 \mathrm{~Hz}, 1 \mathrm{H})$, $6.20(\mathrm{~d}, J=2.8 \mathrm{~Hz}, 1 \mathrm{H}), 6.63(\mathrm{~d}, J=9.8 \mathrm{~Hz}, 2 \mathrm{H}), 6.73(\mathrm{~d}, J=8.7 \mathrm{~Hz}, 1 \mathrm{H}), 6.95(\mathrm{~s}, 1 \mathrm{H}), 7.10-$ $7.23(\mathrm{~m}, 4 \mathrm{H})$.

2-[[4-(3-Aminopropoxy)-2,6-difluoro-phenyl]methylsulfanyl]-N-(3,4-dimethoxyphenyl)-3(4-fluorophenyl)-N-methyl-imidazol-4-amine (25c). Tert-butyl N-tert-butoxycarbonyl-N-[3[4-[[5-(3,4-dimethoxy-N-methyl-anilino)-1-(4-fluorophenyl)imidazol-2-yl]sulfanylmethyl]-3,5difluoro-phenoxy]propyl]carbamate $(180 \mathrm{mg}, 0.24 \mathrm{mmol})$ was diluted in $4 \mathrm{~mL}$ of dry DCM and $400 \mu \mathrm{L}$ of TFA were added. The reaction mixture was stirred at $0^{\circ} \mathrm{C}$ during $30 \mathrm{~min}$ and at room temperature during $5 \mathrm{~h}$. The crude was diluted in DCM, washed with a saturated aqueous solution of $\mathrm{NaHCO}_{3}$, dried over $\mathrm{Na}_{2} \mathrm{SO}_{4}$. The solvent was removed to give $130 \mathrm{mg}$ of the titled compound as yellow oil, leading as a $98 \%$ yield. It was used without further purification in the next step of the synthesis. MS $[\mathrm{M}+\mathrm{H}]^{+} m / z=559 .{ }^{1} \mathrm{H}$ NMR (300 MHz, DMSO-d6): $\delta$ (ppm) 1.74-1.79 (m, 
2H), $2.68(\mathrm{t}, J=6.6 \mathrm{~Hz}, 2 \mathrm{H}), 2.92(\mathrm{~s}, 3 \mathrm{H}), 3.32(\mathrm{~s}, 2 \mathrm{H}), 3.63(\mathrm{~s}, 3 \mathrm{H}), 3.64(\mathrm{~s}, 3 \mathrm{H}), 3.98(\mathrm{~s}, 2 \mathrm{H})$, $4.03(\mathrm{t}, J=6.6 \mathrm{~Hz}, 2 \mathrm{H}), 6.03-6.07(\mathrm{dd}, J=8.8,2.8 \mathrm{~Hz}, 1 \mathrm{H}), 6.20(\mathrm{~d}, J=2.8 \mathrm{~Hz}, 1 \mathrm{H}), 6.67(\mathrm{~d}, J=$ $9.8 \mathrm{~Hz}, 2 \mathrm{H}), 6.73(\mathrm{~d}, J=8.8 \mathrm{~Hz}, 1 \mathrm{H}), 6.96(\mathrm{~s}, 1 \mathrm{H}), 7.09-7.23(\mathrm{~m}, 4 \mathrm{H})$.

2-[3-[4-[[5-(3,4-Dimethoxy-N-methyl-anilino)-1-(4-fluorophenyl)imidazol-2yl]sulfanylmethyl]-3,5-difluoro-phenoxy]propyl-(2-sulfonatoethyl)amino]ethanesulfonate; diammonium (25). In a microwave tube were added 2-[[4-(3-aminopropoxy)-2,6-difluorophenyl]methylsulfanyl]-N-(3,4-dimethoxyphenyl)-3-(4-fluorophenyl)-N-methyl-imidazol-4amine (92 mg, $0.16 \mathrm{mmol})$, Sodium 2-chloroethanesulfonate (219.44 mg, $1.32 \mathrm{mmol})$, sodium iodide $(24.69 \mathrm{mg}, 0.16 \mathrm{mmol})$ and DIEA $(114.75 \mu \mathrm{L}, 0.66 \mathrm{mmol})$ in $700 \mu \mathrm{L}$ of DMF. The reaction mixture was heated under microwave irradiation at $100^{\circ} \mathrm{C}$ for $2 \mathrm{~h}$. The reaction mixture was evaporated to dryness and was purified by preparative HPLC (ammonium formate buffer $\mathrm{pH}$ $=3.8$ ) to give $22 \mathrm{mg}$ of the titled compound as a colorless oil, leading to a $16 \%$ yield. LC-MS: $\mathrm{t}_{\mathrm{R}}$ $=2.65 \mathrm{~min}, \mathrm{MS}[\mathrm{M}+2 \mathrm{H}]^{2+} \mathrm{m} / \mathrm{z}=775$. HRMS found 775.1745; $\mathrm{C}_{32} \mathrm{H}_{35} \mathrm{~F}_{3} \mathrm{~N}_{4} \mathrm{O}_{9} \mathrm{~S}_{3}$ requires 775.1753. ${ }^{1} \mathrm{H}$ NMR (300 MHz, MeOD- $\left.d 4\right): \delta(\mathrm{ppm})$ 2.26-2.32 (m, 2H), $2.98(\mathrm{~s}, 3 \mathrm{H}), 3.26(\mathrm{t}, J=$ $6.7 \mathrm{~Hz}, 4 \mathrm{H}), 3.48$ (t, $J=7.2 \mathrm{~Hz}, 2 \mathrm{H}), 3.65$ (t, $J=6.7 \mathrm{~Hz}, 4 \mathrm{H}), 3.74(\mathrm{~s}, 3 \mathrm{H}), 3.75(\mathrm{~s}, 3 \mathrm{H}), 3.91$ (s, 2H), $4.11(\mathrm{t}, J=5.6 \mathrm{~Hz}, 1 \mathrm{H}), 6.14-6.18(\mathrm{dd}, J=8.6,2.8 \mathrm{~Hz}, 1 \mathrm{H}), 6.29(\mathrm{~d}, J=2.8 \mathrm{~Hz}, 1 \mathrm{H}), 6.58$ $(\mathrm{d}, J=9.5 \mathrm{~Hz}, 2 \mathrm{H}), 6.78(\mathrm{~d}, J=8.6 \mathrm{~Hz}, 1 \mathrm{H}), 6.92-7.07(\mathrm{~m}, 5 \mathrm{H}) .{ }^{13} \mathrm{C}$ NMR $(75 \mathrm{MHz}, \mathrm{MeOD}-$ $d 4): \delta(\mathrm{ppm}) 23.7,26.5,39.6,44.8,50.3,51.4,55.2,56.0,65.7,98.0-98.6(\mathrm{~m}), 101.0,106.0(\mathrm{t}, J$ $=20.1 \mathrm{~Hz}), 106.8,113.3,115.3(\mathrm{~d}, J=23.4 \mathrm{~Hz}), 122.8,129.6,129.7,130.8,137.4,140.7,143.1$, 143.2, 149.8, $159.6(\mathrm{t}, J=14.0 \mathrm{~Hz}), 161.5(\mathrm{dd}, J=246.7,10.9 \mathrm{~Hz}), 162.5(\mathrm{~d}, J=247.9 \mathrm{~Hz})$.

tert-Butyl N-[2-(3,4-dimethoxy-N-methyl-anilino)-1-methyl-2-oxo-ethyl]carbamate (26a). In a $10 \mathrm{~mL}$ flask were added (3,4-Dimethoxy-phenyl)-methyl-amine (3a) (275 mg, $1.55 \mathrm{mmol})$, EtOAc (3 mL), Boc-Ala-OH (351 mg, $1.86 \mathrm{mmol})$, T3P® (1366 $\mu \mathrm{L}, 2.319 \mathrm{mmol})$, and DIEA 
$(810 \mu \mathrm{L}, 4.64 \mathrm{mmol})$. Reaction mixture was then stirred at room temperature for 1 hour. The reaction mixture was diluted with EtOAc, washed with water, saturated aqueous solution of $\mathrm{NaHCO}_{3}$ and brine, and the organic phase was dried over $\mathrm{Na}_{2} \mathrm{SO}_{4}$ and evaporated to give $523 \mathrm{mg}$ of tert-butyl $\mathrm{N}$-[2-(3,4-dimethoxy-N-methyl-anilino)-1-methyl-2-oxo-ethyl]carbamate as a yellow powder, leading to a $66 \%$ yield. MS $[\mathrm{M}+\mathrm{H}]^{+} \mathrm{m} / \mathrm{z}=339.2$.

\section{[2-(3,4-Dimethoxy-N-methyl-anilino)-1-methyl-2-oxo-ethyl]ammonium;2,2,2-}

trifluoroacetate (26b). tert-butyl N-[2-(3,4-dimethoxy-N-methyl-anilino)-1-methyl-2-oxoethyl]carbamate (26a) (345 mg, $1.0 \mathrm{mmol})$ was dissolved in $2.3 \mathrm{~mL}$ of dichloromethane. $1 \mathrm{~mL}$ of TFA was then gently added and reaction mixture was then stirred at room temperature for 30 min. Reaction mixture was then evaporated to dryness, to give [2-(3,4-dimethoxy-N-methylanilino)-1-methyl-2-oxo-ethyl]ammonium;2,2,2-trifluoroacetate as a purple oil. This oil will enter the next step without further purification. Yield was considered to be $100 \%$. MS $[\mathrm{M}+\mathrm{H}]^{+}$ $m / z=239.1$

\section{N-(3,4-Dimethoxy-phenyl)-2-[3-(4-fluoro-phenyl)-isothioureido]-N-methyl-propionamide}

(26c). 4-fluorophenylisothiocyanate $(150 \mathrm{mg}, 0.982 \mathrm{mmol})$ and $\mathrm{NEt}_{3}(159 \mu \mathrm{L}, 1.18 \mathrm{mmol})$ were added in a $50 \mathrm{~mL}$ flask in $3 \mathrm{~mL}$ Ethanol. [2-(3,4-dimethoxy-N-methyl-anilino)-1-methyl-2-oxoethyl]ammonium; 2,2,2-trifluoroacetate (26b) (346 mg, $0.982 \mathrm{mmol}$ ) was dissolved in $10 \mathrm{~mL}$ of ethanol, $\mathrm{NEt}_{3}$ was added until $\mathrm{pH}$ was over 8 and the mixture was added dropwise at room temperature. After the addition, the reaction was over. Reaction mixture was evaporated to dryness, and purified by flash chromatography using as eluent a mixture of cyclohexane/EtOAc (7/3), to give $295 \mathrm{mg}$ of the titled compound as a white powder ( $94 \%$ purity), leading to a $72 \%$ yield. MS $[\mathrm{M}+\mathrm{H}]^{+} \mathrm{m} / \mathrm{z}=392.1 .{ }^{1} \mathrm{H}$ RMN (DMSO- $\left.d 6\right): \delta(\mathrm{ppm}) 1.10(\mathrm{~d}, J=6.9 \mathrm{~Hz}, 3 \mathrm{H}), 3.15(\mathrm{~s}$, 
3H), 3.75-3.80 (m, 6H), $4.99(\mathrm{~m}, 1 \mathrm{H}), 6.96(\mathrm{dd}, J=8.5,2.3 \mathrm{~Hz}, 1 \mathrm{H}), 7.10(\mathrm{~d}, J=8.5 \mathrm{~Hz}, 1 \mathrm{H})$, 7.06-7.19 (m, 3H), 7.41-7.51 (m, 2H), $7.83(\mathrm{~d}, J=7.7 \mathrm{~Hz}, 1 \mathrm{H})$.

2-[2-(2,6-Difluoro-benzyl)-3-(4-fluoro-phenyl)-isothioureido]-N-(3,4-dimethoxy-phenyl)-Nmethyl-propionamide (26d). In a $5 \mathrm{~mL}$ flask were added N-(3,4-dimethoxy-phenyl)-2-[3-(4fluoro-phenyl)-isothioureido]-N-methyl-propionamide (26c) $(75 \mathrm{mg}, 180 \mu \mathrm{mol}), \mathrm{K}_{2} \mathrm{CO}_{3}(26 \mathrm{mg}$, $188 \mu \mathrm{mol})$, sodium iodide $(14 \mathrm{mg}, 93 \mu \mathrm{mol})$, and $1 \mathrm{~mL}$ of acetonitrile (QS $0.2 \mathrm{M}$ ). The suspension was stirred at room temperature for $10 \mathrm{~min}$, and 2-(bromomethyl)-1,3-difluorobenzene (40 mg, $193 \mu \mathrm{mol}$ ) was then added. The suspension was stirred at room temperature for 16 hours. The medium was then evaporated, residue was dissolved in EtOAc, washed with water and brine, organic phase was dried over $\mathrm{Na}_{2} \mathrm{SO}_{4}$ and evaporated to dryness. Residue was purified by flash chromatography using as eluent a mixture of $\mathrm{DCM} / \mathrm{MeOH}(97 / 3)$ to give $78 \mathrm{mg}$ of the titled compound as a white solid, leading to a $84 \%$ yield. $\mathrm{MS}[\mathrm{M}+\mathrm{H}]^{+} \mathrm{m} / \mathrm{z}=518.2 .{ }^{1} \mathrm{H} \mathrm{NMR}$ (300 MHz, $\left.\mathrm{CD}_{2} \mathrm{Cl}_{2}\right): \delta(\mathrm{ppm}) 1.22(\mathrm{~d}, J=6.4 \mathrm{~Hz}, 3 \mathrm{H}), 3.25(\mathrm{~s}, 3 \mathrm{H}), 3.63(\mathrm{~s}, 3 \mathrm{H}), 3.85(\mathrm{~s}, 3 \mathrm{H})$, $4.11(\mathrm{~s}, 2 \mathrm{H}), 4.58$ (brs, 1H), 6.65-7.02 (m, 10H), $7.28(\mathrm{~m}, 1 \mathrm{H})$.

\section{[2-(2,6-Difluoro-benzylsulfanyl)-3-(4-fluoro-phenyl)-5-methyl-3H-imidazol-4-yl]-(3,4-}

dimethoxy-phenyl)-methyl-amine (26). 2-[2-(2,6-Difluoro-benzyl)-3-(4-fluoro-phenyl)isothioureido]-N-(3,4-dimethoxy-phenyl)-N-methyl-propionamide (26d) (78 mg, $0.15 \mathrm{mmol}$ ) was dissolved in $1.5 \mathrm{~mL}$ of dry EtOAc. DIEA $(157.9 \mu \mathrm{L}, 0.90 \mathrm{mmol})$, and T3P® in EtOAc (266 $\mu \mathrm{L}, 0.45 \mathrm{mmol}$ ) were then added. Half of the mixture was heated with microwave at $150^{\circ} \mathrm{C}$ for $10 \mathrm{~min}$. The expected product was observed, starting material has disappeared, but unfortunately, reaction mixture was dirty. The other half of the reaction mixture was heated at reflux for 45 hours. T3P® (3 eq) and DIEA (6 eq) were added after 4, 19, and 24 hours. T3P® (1.5 eq) and DIEA ( 3 eq) were added after 42 hours. Reaction mixture was then diluted with EtOAc, washed 
with water, a saturated aqueous solution of $\mathrm{NaHCO}_{3}$, and brine. Organic phase was then dried over $\mathrm{Na}_{2} \mathrm{SO}_{4}$ and evaporated. Residue was then purified by preparative HPLC (ammonium formate buffer $\mathrm{pH} 3.8$ ) to give $4.5 \mathrm{mg}$ of the titled compound as a yellowish solid, leading to a 6 $\%$ yield. MS $[\mathrm{M}+\mathrm{H}]^{+} \mathrm{m} / z=500.1 .{ }^{1} \mathrm{H} \mathrm{NMR}\left(300 \mathrm{MHz}, \mathrm{CDCl}_{3}\right): \delta(\mathrm{ppm}) 2.11\left(\mathrm{~s}, 3 \mathrm{H}, \mathrm{CH}_{3}\right), 2.87$ (s, $\left.3 \mathrm{H}, \mathrm{N}-\underline{\mathrm{CH}_{3}}\right), 3.84$ (s, 3H, O- $\left.\underline{\mathrm{CH}_{3}}\right), 3.86$ (s, 3H, O- $\left.\underline{\mathrm{CH}}_{3}\right), 4.13$ (s, $\left.2 \mathrm{H}, \mathrm{S}-\underline{\mathrm{CH}_{2}}\right), 6.10$ (dd, J = 8.7, $2.8 \mathrm{~Hz}, 1 \mathrm{H}, \mathrm{Ar}), 6.23$ (d, J=2.8 Hz, 1H, Ar), 6.76-6.83 (m, 3H, Ar), 6.93-6.97 (m, 4H, Ar), 7.19 (m, 1H, Ar). ${ }^{13} \mathrm{C}$ NMR $\left(75 \mathrm{MHz}, \mathrm{CDCl}_{3}\right): \delta$ (ppm) 12.4, 26.3, 38.6, 55.9, 56.5, 98.1, 103.5, 111.1-111.3 (m), 112.7, $113.8(\mathrm{t}, J=19.6 \mathrm{~Hz}), 115.9(\mathrm{~d}, J=22.9 \mathrm{~Hz}), 128.9(\mathrm{~d}, J=8.6 \mathrm{~Hz})$, $129.1(\mathrm{t}, J=10.0 \mathrm{~Hz}), 131.2,133.6,134.4,136.6,142.0,142.9,149.8,161.2(\mathrm{dd}, J=249.9,7.7$ $\mathrm{Hz}), 162.1(\mathrm{~d}, J=248.8 \mathrm{~Hz})$.

9H-Fluoren-9-ylmethyl N-[(5S)-5-(tert-butoxycarbonylamino)-6-(3,4-dimethoxy-N-methylanilino)-6-oxo-hexyl]carbamate (27a). In a $50 \mathrm{~mL}$ flask were added 3,4-dimethoxy-N-methylaniline (3a) (500 mg, $2.99 \mathrm{mmol}), 6 \mathrm{~mL}$ of EtOAc, (2R)-2-(tert-butoxycarbonylamino)-6-(9Hfluoren-9-ylmethoxycarbonylamino)hexanoic acid (1681.33 mg, $3.59 \mathrm{mmol})$, DIEA (1.57 mL, $8.97 \mathrm{mmol})$ and $\mathrm{T} 3 \mathrm{P} ®(2.64 \mathrm{~mL}, 4.49 \mathrm{mmol})$. The reaction mixture was then stirred at $50^{\circ} \mathrm{C}$ for 1 hour. The reaction mixture was diluted in EtOAc, washed with a saturated aqueous solution of $\mathrm{NaHCO}_{3}$ and with brine, and the organic phase was dried over $\mathrm{MgSO}_{4}$ and evaporated to dryness to give $1.85 \mathrm{~g}$ of the titled compound as dark red oil, leading to a quantitative yield. It was used without further purification in the next step of the synthesis. MS $[\mathrm{M}+\mathrm{H}]^{+} \mathrm{m} / \mathrm{z}=618$.

[(1S)-1-[(3,4-Dimethoxyphenyl)-methyl-carbamoyl]-5-(9H-fluoren-9-

ylmethoxycarbonylamino)pentyl]ammonium;2,2,2-trifluoroacetate $\quad(27 b) . \quad 9 H-f l u o r e n-9-$ ylmethyl N-[(5S)-5-(tert-butoxycarbonylamino)-6-(3,4-dimethoxy-N-methyl-anilino)-6-oxohexyl]carbamate (27a) $(1.85 \mathrm{~g}, 2.99 \mathrm{mmol})$ and TFA (2.56 mL, $33.42 \mathrm{mmol})$ were dissolved in 5 
$\mathrm{mL}$ of DCM. The reaction mixture was stirred at room temperature for $1 \mathrm{~h} .1 \mathrm{~mL}$ of TFA was added again at the reaction mixture ant it was stirred at room temperature for 30 minutes. The reaction mixture was evaporated to dryness to give $1.58 \mathrm{~g}$ of the titled compound as purple oil, leading to a quantitative yield. It was used without further purification in the next step of the synthesis. MS $[\mathrm{M}+\mathrm{H}]^{+} m / z=518$.

9H-Fluoren-9-ylmethyl $\quad \mathrm{N}$-[(5S)-6-(3,4-dimethoxy-N-methyl-anilino)-5-[[(Z)-N-(4fluorophenyl)-C-sulfanyl-carbonimidoyl]amino]-6-oxo-hexyl]carbamate (27c). 1-fluoro-4isothiocyanato-benzene $(0.46 \mathrm{~g}, 2.99 \mathrm{mmol})$ and $\mathrm{NEt}_{3}(0.4 \mathrm{~mL}, 2.99 \mathrm{mmol})$ were added in a 500 $\mathrm{mL}$ flask in $20 \mathrm{~mL}$ of ethanol. [(1S)-1-[(3,4-dimethoxyphenyl)-methyl-carbamoyl]-5-(9Hfluoren-9-ylmethoxycarbonylamino)pentyl]ammonium;2,2,2-trifluoroacetate (27b) (1.89 g, 2.99 mmol) was dissolved in $20 \mathrm{~mL}$ of ethanol, $\mathrm{NEt}_{3}(0.47 \mathrm{~mL}, 3.47 \mathrm{mmol})$ were added, and the mixture was added dropwise at room temperature. Then $1 \mathrm{~mL}$ of $\mathrm{NEt}_{3}$ was added to reach $\mathrm{pH} 10$. The reaction mixture was evaporated to dryness. Purification of the crude by flash chromatography using as eluent a mixture of cyclohexane/EtOAc (50/50) gave $1.58 \mathrm{~g}$ of the titled compound as yellowish oil, leading to a 79\% yield. MS $[\mathrm{M}+\mathrm{H}]^{+} \mathrm{m} / z=671 .{ }^{1} \mathrm{H}$ NMR $(300$ $\left.\mathrm{MHz}, \mathrm{CDCl}_{3}\right): \delta(\mathrm{ppm}) 1.09-1.36(\mathrm{~m}, 4 \mathrm{H}), 1.46-1.70(\mathrm{~m}, 2 \mathrm{H}), 3.00(\mathrm{~s}, 2 \mathrm{H}), 3.20(\mathrm{~s}, 3 \mathrm{H}), 3.87(\mathrm{~s}$, 3H), $3.93(\mathrm{~s}, 3 \mathrm{H}), 4.18(\mathrm{~d}, J=7.3 \mathrm{~Hz}, 1 \mathrm{H}), 4.36(\mathrm{~d}, J=7.1 \mathrm{~Hz}, 2 \mathrm{H}), 4.91(\mathrm{t}, J=5.6 \mathrm{~Hz}, 1 \mathrm{H})$, $6.88(\mathrm{~s}, 2 \mathrm{H}), 6.99(\mathrm{t}, J=8.5 \mathrm{~Hz}, 2 \mathrm{H}), 7.12(\mathrm{~s}, 1 \mathrm{H}), 7.20-7.42(\mathrm{~m}, 6 \mathrm{H}), 7.57(\mathrm{~d}, J=7.4 \mathrm{~Hz}, 2 \mathrm{H})$, $7.67(\mathrm{~s}, 1 \mathrm{H}), 7.74(\mathrm{~d}, J=7.4 \mathrm{~Hz}, 2 \mathrm{H}), 8.51(\mathrm{~s}, 1 \mathrm{H})$.

9H-Fluoren-9-ylmethyl $\quad \mathrm{N}-[(5 \mathrm{~S})-5-[[(Z)-C-[(2,6-d i f l u o r o p h e n y l) m e t h y l s u l f a n y l]-N-(4-$ fluorophenyl)carbonimidoyl]amino]-6-(3,4-dimethoxy-N-methyl-anilino)-6-oxo-

hexyl]carbamate (27d). In a $25 \mathrm{~mL}$ flask were added 2-(bromomethyl)-1,3-difluoro-benzene (486.14 mg, $2.348 \mathrm{mmol}), \mathrm{K}_{2} \mathrm{CO}_{3}(357.02 \mathrm{mg}, 2.583 \mathrm{mmol})$ and $11.7 \mathrm{~mL}$ of acetonitrile. The 
suspension was stirred at room temperature for 10 minutes and $9 \mathrm{H}$-fluoren-9-ylmethyl $\mathrm{N}-[(5 \mathrm{~S})$ 6-(3,4-dimethoxy-N-methyl-anilino)-5-[[(4-fluoroanilino)-sulfanyl-methyl]amino]-6-oxohexyl]carbamate $(\mathbf{2 7 c})(1.58 \mathrm{~g}, 2.35 \mathrm{mmol})$ was then added. The suspension was stirred at room temperature overnight. The reaction mixture was then evaporated, residue was dissolved in EtOAc, washed with water and brine, organic phase was dried over $\mathrm{MgSO}_{4}$ and evaporated to dryness to give $1.87 \mathrm{~g}$ of the desired product as dark oil, leading to a $89 \%$ yield. It was used without further purification in the next step of the synthesis. MS $[\mathrm{M}+\mathrm{H}]^{+} \mathrm{m} / z=799 .{ }^{1} \mathrm{H}$ NMR (300 MHz, $\mathrm{CDCl}_{3}$ ): $\delta$ (ppm) 1.30 (brs, 4H), 1.62 (brs, 3H), 3.08 (brs, 2H), 3.27 (brs, 3H), 3.62 (s, 3H), 3.84 (s, 3H), 4.08 (brs, 2H), $4.19(\mathrm{~m}, 1 \mathrm{H}), 4.39$ (d, $J=6.9 \mathrm{~Hz}, 2 \mathrm{H}), 4.70$ (brs, 1H), 5.24 (brs, 1H), 6.74 (brs, 1H), 6.75-6.95 (m, 8H), 7.15-7.23 (m, 1H), 7.30 (t, J = 7.4 Hz, 2H), 7.39 (t, $J=7.4 \mathrm{~Hz}, 2 \mathrm{H}), 7.57(\mathrm{~d}, J=7.2 \mathrm{~Hz}, 2 \mathrm{H}), 7.76(\mathrm{~d}, J=7.2 \mathrm{~Hz}, 2 \mathrm{H})$.

9H-Fluoren-9-ylmethyl N-[4-[2-[(2,6-difluorophenyl)methylsulfanyl]-5-(3,4-dimethoxy-Nmethyl-anilino)-1-(4-fluorophenyl)imidazol-4-yl]butyl]carbamate (27e). In a $50 \mathrm{~mL}$ flask were added 9H-fluoren-9-ylmethyl N-[(5S)-5-[[(Z)-C-[(2,6-difluorophenyl)methylsulfanyl]-N(4-fluorophenyl)carbonimidoyl]amino]-6-(3,4-dimethoxy-N-methyl-anilino)-6-oxo-

hexyl]carbamate (27d) (1.625 mg, $2.039 \mathrm{mmol}), \mathrm{T} 3 \mathrm{P} 囚(3.605 \mathrm{~mL}, 6.117 \mathrm{mmol})$, DIEA (2.137 $\mathrm{mL}, 12.23 \mathrm{mmol}$ ) and $20.39 \mathrm{~mL}$ of EtOAc. The suspension was stirred 24 hours at $80^{\circ} \mathrm{C}$. Same quantities of $\mathrm{T} 3 \mathrm{P} \circledast$ and DIEA were added twice at 24 and $48 \mathrm{~h}$. The medium was then evaporated, the residue was dissolved in EtOAc, washed with water and brine, organic phase was dried over $\mathrm{MgSO}_{4}$ and evaporated. Purification of the crude by flash chromatography using as eluent a mixture of cyclohexane/EtOAc (7/3) gave $507 \mathrm{mg}$ of the titled compound as a yellow solid, leading to a $32 \%$ yield. $\mathrm{MS}[\mathrm{M}+\mathrm{H}]^{+} \mathrm{m} / z=779 .{ }^{1} \mathrm{H} \mathrm{NMR}\left(300 \mathrm{MHz}, \mathrm{CDCl}_{3}\right): \delta(\mathrm{ppm})$ $1.42-1.56(\mathrm{~m}, 2 \mathrm{H}), 1.61-1.74(\mathrm{~m}, 2 \mathrm{H}), 2.43(\mathrm{t}, J=7.4 \mathrm{~Hz}, 2 \mathrm{H}), 2.83(\mathrm{~s}, 3 \mathrm{H}), 3.15-3.22(\mathrm{~m}, 2 \mathrm{H})$, 
$3.80(\mathrm{~s}, 3 \mathrm{H}), 3.81(\mathrm{~s}, 3 \mathrm{H}), 4.07(\mathrm{~s}, 2 \mathrm{H}), 4.21(\mathrm{t}, J=6.8 \mathrm{~Hz}, 2 \mathrm{H}), 4.38(\mathrm{~d}, J=7.0 \mathrm{~Hz}, 2 \mathrm{H}), 5.03$ (brs, 1H), 6.04 (dd, $J=8.7,2.8 \mathrm{~Hz}, 1 \mathrm{H}), 6.18(\mathrm{~d}, J=2.8 \mathrm{~Hz}, 1 \mathrm{H}), 6.70-6.81(\mathrm{~m}, 3 \mathrm{H}), 6.88-6.94$ (m, 4H), 7.09-7.20 (m, 1H), 7.30(t, $J=7.4 \mathrm{~Hz}, 2 \mathrm{H}), 7.38(\mathrm{~d}, J=7.4 \mathrm{~Hz}, 2 \mathrm{H}), 7.60(\mathrm{~d}, J=7.2 \mathrm{~Hz}$, $2 \mathrm{H}), 7.75(\mathrm{~d}, J=7.2 \mathrm{~Hz}, 2 \mathrm{H})$.

\section{4-[2-[(2,6-Difluorophenyl)methylsulfanyl]-5-(3,4-dimethoxy-N-methyl-anilino)-1-(4-}

fluorophenyl)imidazol-4-yl]butylammonium;formate (27). To a solution of 9H-fluoren-9ylmethyl N-[4-[2-[(2,6-difluorophenyl)methylsulfanyl]-5-(3,4-dimethoxy-N-methyl-anilino)-1(4-fluorophenyl)imidazol-4-yl]butyl]carbamate (27e) $(0.24 \mathrm{~g}, 0.31 \mathrm{mmol})$ in EtOAc $(1.45 \mathrm{~mL})$ was added piperidine $(0.06 \mathrm{~mL}, 0.62 \mathrm{mmol})$. The reaction mixture was stirred at room temperature overnight. The reaction mixture was then evaporated under reduced pressure. Purification of the crude by preparative HPLC (ammonium formate buffer $\mathrm{pH} 3.8$ ) gave $100 \mathrm{mg}$ of the desired product as yellowish oil, leading to a $60 \%$ yield. MS $[\mathrm{M}+\mathrm{H}]^{+} \mathrm{m} / z=557$. HRMS found 585.2126; $\mathrm{C}_{30} \mathrm{H}_{31} \mathrm{~F}_{3} \mathrm{~N}_{4} \mathrm{O}_{3} \mathrm{~S}$ requires 585.2147. ${ }^{1} \mathrm{H} \mathrm{NMR}\left(300 \mathrm{MHz}, \mathrm{CDCl}_{3}\right)$ : $\delta$ (ppm) 1.60$1.80(\mathrm{~m}, 4 \mathrm{H}), 2.32-2.50(\mathrm{~m}, 2 \mathrm{H}), 2.82(\mathrm{~s}, 3 \mathrm{H}), 2.90-3.00(\mathrm{~m}, 2 \mathrm{H}), 3.80(\mathrm{~s}, 3 \mathrm{H}), 3.81(\mathrm{~s}, 3 \mathrm{H}), 3.94$ (s, 2H), $6.03(\mathrm{dd}, J=8.7,2.4 \mathrm{~Hz}, 1 \mathrm{H}), 6.17(\mathrm{~d}, J=2.4 \mathrm{~Hz}, 1 \mathrm{H}), 5.50-6.50(\mathrm{~m}, 3 \mathrm{H}), 6.70-6.82(\mathrm{~m}$, $3 \mathrm{H}), 6.83-6.95(\mathrm{~m}, 4 \mathrm{H}), 7.10-7.21(\mathrm{~m}, 1 \mathrm{H}), 8.46$ (brs, $1 \mathrm{H}) .{ }^{13} \mathrm{C} \mathrm{NMR}\left(75 \mathrm{MHz}, \mathrm{CDCl}_{3}\right): \delta(\mathrm{ppm})$ $25.8,25.9,26.9,27.6,39.0,56.0,56.6,70.6,98.2,103.8,111.3(\mathrm{~m}), 112.9,114.0(\mathrm{t}, J=19.3$ Hz), $115.9(\mathrm{~d}, J=22.8 \mathrm{~Hz}), 129.2(\mathrm{~d}, J=9.0 \mathrm{~Hz}), 129.3(\mathrm{t}, J=9.2 \mathrm{~Hz}), 131.1(\mathrm{~d}, J=3.1 \mathrm{~Hz})$, 134.7, 136.4, 137.2, 142.2, 142.9, 149.9, 161.1 (dd, $J=249.7,7.8 \mathrm{~Hz}), 162.3(\mathrm{~d}, J=249.1 \mathrm{~Hz})$, 168.6.

Methyl (4S)-4-(tert-butoxycarbonylamino)-5-(3,4-dimethoxy-N-methyl-anilino)-5-oxopentanoate (28a). In a $50 \mathrm{~mL}$ flask were added 3,4-dimethoxy-N-methyl-aniline (Intermediate 1a) (500 mg, $2.99 \mathrm{mmol}), 6 \mathrm{~mL}$ of EtOAc, (2R)-2-(tert-butoxycarbonylamino)-5-methoxy-5- 
oxo-pentanoic acid (937.55 mg, $3.59 \mathrm{mmol}), \mathrm{T} 3 \mathrm{P} ®(2.64 \mathrm{~mL}, 4.49 \mathrm{mmol})$ and DIEA (1.57 mL, $8.97 \mathrm{mmol})$. The reaction mixture was then stirred at $50^{\circ} \mathrm{C}$ for 1 hour. The reaction mixture was diluted in EtOAc, washed with a saturated aqueous solution of $\mathrm{NaHCO}_{3}$ and with brine, and the organic phase was dried over $\mathrm{MgSO}_{4}$ and evaporated to dryness to give $1.187 \mathrm{~g}$ of the desired product as brown oil, leading to a $97 \%$ yield. It was used without further purification in the next step of the synthesis. MS $[\mathrm{M}+\mathrm{H}]^{+} m / z=411$.

(1S)-1-[(3,4-Dimethoxyphenyl)-methyl-carbamoyl]-4-methoxy-4-oxo-

butyl]ammonium;2,2,2-trifluoroacetate (28b). Methyl (4S)-4-(tert-butoxycarbonylamino)-5(3,4-dimethoxy-N-methyl-anilino)-5-oxo-pentanoate (28a) $(1.19 \mathrm{~g}, 2.89 \mathrm{mmol})$ and $1.5 \mathrm{~mL}$ of TFA were dissolved in $5 \mathrm{~mL}$ of DCM and the reaction mixture was stirred at room temperature for $1 \mathrm{~h}$. The reaction mixture was evaporated to dryness to give $1.23 \mathrm{~g}$ of the titled compound as purple oil. The product will be used in the next step of the synthesis without further purification (yield was considered to be $100 \%$ ). MS $[\mathrm{M}+\mathrm{H}]^{+} \mathrm{m} / z=311$.

Methyl (4S)-5-(3,4-dimethoxy-N-methyl-anilino)-4-[[(Z)-N-(4-fluorophenyl)-C-sulfanylcarbonimidoyl]amino]-5-oxo-pentanoate (28c). 4-fluorophenylisothiocyanate (0.44 g, 2.89 mmol) and $\mathrm{NEt}_{3}(0.39 \mathrm{~mL}, 2.89 \mathrm{mmol})$ were added in a $500 \mathrm{~mL}$ flask in $20 \mathrm{~mL}$ of ethanol. (1S)1-[(3,4-dimethoxyphenyl)-methyl-carbamoyl]-4-methoxy-4-oxo-butyl]ammonium;2,2,2trifluoroacetate $(\mathbf{2 8 b})(1.23 \mathrm{~g}, 2.89 \mathrm{mmol})$ was dissolved in $20 \mathrm{~mL}$ of ethanol, $\mathrm{NEt}_{3}(0.47 \mathrm{~mL}$, $3.47 \mathrm{mmol}$ ) were added, and the mixture was added dropwise at room temperature Then $1 \mathrm{~mL}$ of $\mathrm{NEt}_{3}$ are added to reach $\mathrm{pH} 10$. After 30 min of reaction, the conversion was complete. The reaction mixture was evaporated to dryness. Purification of the crude by flash chromatography using as eluent a mixture of cyclohexane/EtOAc (50/50) gave $940 \mathrm{mg}$ of the titled compound as yellowish oil, leading to a $70 \%$ yield. MS $[\mathrm{M}+\mathrm{H}]^{+} \mathrm{m} / z=464 .{ }^{1} \mathrm{H}$ NMR $\left(300 \mathrm{MHz}, \mathrm{CDCl}_{3}\right): \delta$ 
(ppm) $1.73-1.89(\mathrm{~m}, 1 \mathrm{H}) ; 1.89-2.03(\mathrm{~m}, 2 \mathrm{H}), 2.10-2.37(\mathrm{~m}, 2 \mathrm{H}), 3.22(\mathrm{~s}, 3 \mathrm{H}), 3.57(\mathrm{~s}, 3 \mathrm{H}), 3.92$ (s, 3H), $3.94(\mathrm{~s}, 3 \mathrm{H}), 6.91(\mathrm{~s}, 2 \mathrm{H}), 7.00-7.12(\mathrm{~m}, 3 \mathrm{H}), 7.27(\mathrm{~s}, 2 \mathrm{H}), 7.28(\mathrm{~m}, 1 \mathrm{H}), 8.26(\mathrm{~s}, 1 \mathrm{H})$.

Methyl

(4S)-4-[[(Z)-C-[(2,6-difluorophenyl)methylsulfanyl]-N-(4fluorophenyl)carbonimidoyl]amino]-5-(3,4-dimethoxy-N-methyl-anilino)-5-oxo-pentanoate (28d). In a $50 \mathrm{~mL}$ flask were added methyl 2-(bromomethyl)-1,3-difluoro-benzene (419.82 mg, $2.03 \mathrm{mmol}), \mathrm{K}_{2} \mathrm{CO}_{3}(308.3 \mathrm{mg}, 2.23 \mathrm{mmol})$ and $10.2 \mathrm{~mL}$ of acetonitrile. The suspension was stirred at room temperature for $10 \mathrm{~min}$, and methyl (4S)-5-(3,4-dimethoxy-N-methyl-anilino)-4[(4-fluorophenyl)carbamothioylamino]-5-oxo-pentanoate (28c) $(940 \mathrm{mg}, 2.03 \mathrm{mmol})$ was then added at the reaction mixture and it was stirred at room temperature overnight. The medium was then evaporated, residue was dissolved in EtOAc, washed with water, brine, and dried over MgSO4. The crude was evaporated to dryness to give $1.05 \mathrm{~g}$ of the desired product as dark oil, leading to a $87 \%$ yield. It was used without further purification in the next step of the synthesis. MS $[\mathrm{M}+\mathrm{H}]^{+} \mathrm{m} / \mathrm{z}=590 .{ }^{1} \mathrm{H} \mathrm{NMR}\left(300 \mathrm{MHz}, \mathrm{CDCl}_{3}\right): \delta$ (ppm) 1.93 (brs, 2H), 2.29 (brs, 2H), $3.27(\mathrm{~s}, 3 \mathrm{H}), 3.60(\mathrm{~s}, 3 \mathrm{H}), 3.66(\mathrm{~s}, 3 \mathrm{H}), 3.88(\mathrm{~s}, 4 \mathrm{H}), 4.10$ (brs, 2H), 4.70 (brs, 1H), 5.40 (brs, 1H), 6.72 (brs, 2H), 6.83-6.94 (m, 8H).

Methyl 3-[2-[(2,6-difluorophenyl)methylsulfanyl]-5-(3,4-dimethoxy-N-methyl-anilino)-1-(4fluorophenyl)imidazol-4-yl]propanoate (28). In a $100 \mathrm{~mL}$ flask, were added methyl (4S)-4[[(Z)-C-[(2,6-difluorophenyl)methylsulfanyl]-N-(4-fluorophenyl)carbonimidoyl]amino]-5-(3,4dimethoxy-N-methyl-anilino)-5-oxo-pentanoate (28d) $(1 \mathrm{~g}, 1.7 \mathrm{mmol}), \mathrm{T} 3 \mathrm{P} \circledast(3.01 \mathrm{~mL}, 5.1$ mmol), DIEA (1.88 mL, $10.21 \mathrm{mmol})$, and $17 \mathrm{~mL}$ of EtOAc. The medium was stirred at $80^{\circ} \mathrm{C}$ for 24 hours. The reaction mixture was diluted in EtOAc and washed with water, brine, and dried over $\mathrm{MgSO}_{4}$ and evaporated to dryness. The conversion was not complete. The residue was dissolved in $17 \mathrm{~mL}$ of EtOAc. T3P® $(3.01 \mathrm{~mL}, 5.1 \mathrm{mmol})$, DIEA $(1.88 \mathrm{~mL}, 10.21 \mathrm{mmol})$ were 
added at the reaction mixture and it was stirred at $80^{\circ} \mathrm{C}$ for $24 \mathrm{~h}$. The reaction mixture was diluted in EtOAc, washed with water and brine. Organic phase was dried over $\mathrm{MgSO}_{4}$ and evaporated. The crude was purified by flash chromatography using as eluent a mixture of cyclohexane/EtOAc (70/30) to give $265 \mathrm{mg}$ of the desired product with the starting material. The crude was again dissolved in EtOAc and T3P® $(0.6 \mathrm{~mL}, 1.018 \mathrm{mmol})$, DIEA (0.376 mL, 2.035 mmol) were added and the reaction mixture was stirred at $80^{\circ} \mathrm{C}$ for 24 hours. The reaction mixture was diluted in EtOAc, washed with water and brine. Organic phase was dried over $\mathrm{MgSO}_{4}$ and evaporated. The crude was then purified by flash chromatography using as eluent a mixture of cyclohexane/EtOAc (70/30) to give $104 \mathrm{mg}$ of the desired product as yellowish oil, leading to a $11 \%$ yield. MS $[\mathrm{M}+\mathrm{H}]^{+} \mathrm{m} / z=572.2$. HRMS found 572.1814; $\mathrm{C}_{29} \mathrm{H}_{28} \mathrm{~F}_{3} \mathrm{~N}_{3} \mathrm{O}_{4} \mathrm{~S}$ requires 572.1831. ${ }^{1} \mathrm{H} \mathrm{NMR}\left(300 \mathrm{MHz}, \mathrm{CDCl}_{3}\right): \delta(\mathrm{ppm})$ 2.67-2.72 (m, 4H), $2.85(\mathrm{~s}, 3 \mathrm{H}), 3.62$ (s, 3H), $3.79(\mathrm{~s}, 3 \mathrm{H}), 3.80(\mathrm{~s}, 3 \mathrm{H}), 4.07(\mathrm{~s}, 2 \mathrm{H}), 6.04(\mathrm{dd}, J=8.7,2.8 \mathrm{~Hz}, 1 \mathrm{H}), 6.17(\mathrm{~d}, J=2.8$ $\mathrm{Hz}, 1 \mathrm{H}), 6.72(\mathrm{~d}, J=8.7 \mathrm{~Hz}, 1 \mathrm{H}), 6.77(\mathrm{t}, J=7.7 \mathrm{~Hz}, 2 \mathrm{H}), 6.87-6.92(\mathrm{~m}, 4 \mathrm{H}), 7.01-7.21(\mathrm{~m}, 1 \mathrm{H})$.

\section{3-[2-[(2,6-Difluorophenyl)methylsulfanyl]-5-(3,4-dimethoxy-N-methyl-anilino)-1-(4-}

\section{fluorophenyl)imidazol-4-yl]propanoic acid (29). Methyl 3-[2-[(2,6-}

difluorophenyl)methylsulfanyl]-5-(3,4-dimethoxy-N-methyl-anilino)-1-(4-

fluorophenyl)imidazol-4-yl]propanoate (28) (104.6 mg, $0.18 \mathrm{mmol})$ was dissolved in $\mathrm{MeOH}$ $(1.83 \mathrm{~mL})$ and $\mathrm{NaOH} 1 \mathrm{~N}(640 \mu \mathrm{L}, 0.64 \mathrm{mmol})$ was added. The mixture was stirred overnight at room temperature and evaporated to dryness. The residue was dissolved in DCM and washed with aqueous $1 \mathrm{~N} \mathrm{HCl}$, water and brine. The organic phase was dried over $\mathrm{MgSO}_{4}$ and evaporated to dryness to give $95 \mathrm{mg}$ of the titled compound as yellowish oil, leading to a $93 \%$ yield. MS $[\mathrm{M}+\mathrm{H}]^{+} m / z=558.3$. HRMS found 558.1650; $\mathrm{C}_{28} \mathrm{H}_{26} \mathrm{~F}_{3} \mathrm{~N}_{3} \mathrm{O}_{4} \mathrm{~S}$ requires 558.1674. ${ }^{1} \mathrm{H}$ NMR (300 $\left.\mathrm{MHz}, \mathrm{CDCl}_{3}\right): \delta(\mathrm{ppm}) 2.73(\mathrm{~s}, 4 \mathrm{H}), 2.84(\mathrm{~s}, 3 \mathrm{H}), 3.79(\mathrm{~s}, 3 \mathrm{H}), 3.80(\mathrm{~s}, 3 \mathrm{H}), 4.09(\mathrm{~s}, 2 \mathrm{H}), 6.03$ 
$(\mathrm{dd}, J=8.7,2.6 \mathrm{~Hz}, 1 \mathrm{H}), 6.16(\mathrm{~d}, J=2.6 \mathrm{~Hz}, 1 \mathrm{H}), 6.73(\mathrm{~d}, J=8.7 \mathrm{~Hz}, 1 \mathrm{H}), 6.78(\mathrm{t}, J=7.9 \mathrm{~Hz}$, 2H), 6.85-6.98 (m, 4H), 7.11-7.23 (m, 1H), 8.75 (brs, $1 \mathrm{H}) .{ }^{13} \mathrm{C} \mathrm{NMR}\left(75 \mathrm{MHz}, \mathrm{CDCl}_{3}\right): \delta(\mathrm{ppm})$ 21.1, 26.7, 33.5, 38.9, 56.1, 56.5, 98.4, 104.1, $111.4(\mathrm{~m}), 112.9,113.4$ (t, $J=19.2 \mathrm{~Hz}), 116.2$ (d, $J=23.0 \mathrm{~Hz}), 129.1(\mathrm{~d}, J=8.9 \mathrm{~Hz}), 129.6(\mathrm{t}, J=10.2 \mathrm{~Hz}), 130.4(\mathrm{~d}, J=3.2 \mathrm{~Hz}), 134.6,135.2$, 137.1, 142.5, 150.0, $161.1(\mathrm{dd}, J=250.0,7.6 \mathrm{~Hz}), 162.5(\mathrm{~d}, J=250.0 \mathrm{~Hz}), 175.8$.

\section{4-[2-[(2,6-Difluorophenyl)methylsulfanyl]-5-(3,4-dimethoxy-N-methyl-anilino)-1-(4-}

fluorophenyl)imidazol-4-yl]butyl-trimethyl-ammonium;formate (30). In a $5 \mathrm{~mL}$ flask was diluted 4-[2-[(2,6-difluorophenyl)methylsulfanyl]-5-(3,4-dimethoxy-N-methyl-anilino)-1-(4fluorophenyl)imidazol-4-yl]butylammonium;formate (27) (45 mg, $0.07 \mathrm{mmol})$ in $400 \mu \mathrm{L}$ of a mixture of $\mathrm{Et}_{2} \mathrm{O} / \mathrm{THF}(1 / 1)$. Iodomethane $(18.59 \mu \mathrm{L}, 0.3 \mathrm{mmol})$ and DIEA (13.01 $\mu \mathrm{L}, 0.07$ mmol) were added at the reaction mixture and it was stirred at room temperature overnight. The reaction mixture was evaporated to dryness. In a $5 \mathrm{~mL}$ flask was diluted 4-[2-[(2,6difluorophenyl)methylsulfanyl]-5-(3,4-dimethoxy-N-methyl-anilino)-1-(4-

fluorophenyl)imidazol-4-yl]butylammonium;formate (30 mg, $0.05 \mathrm{mmol}$ ) in $250 \mu \mathrm{L}$ of a mixture of $\mathrm{Et}_{2} \mathrm{O} / \mathrm{THF}(1 / 1)$. Iodomethane $(12.4 \mu \mathrm{L}, 0.2 \mathrm{mmol})$ and DIEA (8.67 $\left.\mu \mathrm{L}, 0.05 \mathrm{mmol}\right)$ were added at the reaction mixture and it was stirred at room temperature overnight. The reaction mixture was evaporated to dryness. The crude was diluted in EtOAc and washed with water and brine, dried over $\mathrm{MgSO}_{4}$ and evaporated to dryness. Purification of the crude by preparative chromatography (ammonium formate buffer $\mathrm{pH} 3.8$ ) gave $7.3 \mathrm{mg}$ of the desired product as yellowish oil, leading to a $20 \%$ yield. MS $[\mathrm{M}+\mathrm{H}]^{+} \mathrm{m} / z=599$. HRMS found 599.2665; $\mathrm{C}_{32} \mathrm{H}_{38} \mathrm{~F}_{3} \mathrm{~N}_{4} \mathrm{O}_{2} \mathrm{~S}$ requires 599.2668. ${ }^{1} \mathrm{H}$ NMR $\left(300 \mathrm{MHz}, \mathrm{CDCl}_{3}\right.$ ): $\delta$ (ppm) 1.69 (brs, $\left.2 \mathrm{H}\right), 1.82$ (brs, 2H), 2.45 (t, $J=6.6 \mathrm{~Hz}, 2 \mathrm{H}), 2.87$ (s, 3H), 3.31 (brs, 9H), 3.45 (brs, 2H), 3.82 (s, 3H), 3.83 (s, 3H), $4.03(\mathrm{~s}, 2 \mathrm{H}), 6.06(\mathrm{dd}, J=8.6,2.6 \mathrm{~Hz}, 1 \mathrm{H}), 6.18(\mathrm{~d}, J=2.7 \mathrm{~Hz}, 1 \mathrm{H}), 6.76(\mathrm{~d}, J=8.6 \mathrm{~Hz}$, 
1H), $6.81(\mathrm{t}, J=7.8 \mathrm{~Hz}, 2 \mathrm{H}), 6.90-6.98(\mathrm{~m}, 4 \mathrm{H}), 7.15-7.25(\mathrm{~m}, 1 \mathrm{H}), 8.61(\mathrm{~s}, 1 \mathrm{H}),{ }^{13} \mathrm{C} \mathrm{NMR}(75$ $\left.\mathrm{MHz}, \mathrm{CDCl}_{3}\right): \delta(\mathrm{ppm}) \quad 22.6,25.3,25.6,26.6,29.8,34.1,39.2,53.5,56.2,56.7,66.9,98.5$, 104.1, $111.5(\mathrm{~m}), 113.0,114.1(\mathrm{t}, J=19.2 \mathrm{~Hz}), 116.1(\mathrm{~d}, J=22.9 \mathrm{~Hz}), 129.1(\mathrm{~d}, J=8.4 \mathrm{~Hz})$, $129.4(\mathrm{t}, J=10.2 \mathrm{~Hz}), 131.1(\mathrm{~d}, J=3.1 \mathrm{~Hz}), 134.9,136.3,136.9,142.3,143.0,149.9,161.2(\mathrm{dd}$, $J=249.3,7.8 \mathrm{~Hz}), 162.4(\mathrm{~d}, J=249.3 \mathrm{~Hz})$.

\section{AUTHOR INFORMATION}

\section{Corresponding Author}

*For B.D.: phone, +33 (0)320 964 924; fax, +33 (0) 320 964; 709;

e-mail: benoit.deprez@univ-lille2.fr

*For JC.: phone, +33 (0)320 964 928;

email: julie.charton@univ-lille2.fr

\section{Author Contributions}

\footnotetext{
\# These authors contributed equally.

$\diamond$ These authors contributed equally.
}

\section{ACKNOWLEDGMENT}

We are grateful to the institutions that support our laboratory: INSERM, Universite de Lille, Institut Pasteur de Lille. This project was supported by Conseil Régional Nord-Pas de Calais, ERDF (convention n¹1003609), Etat DRRT, European Genomic Institute for Diabetes'(EGID, ANR-10-LABX-46), the European Research Council (ERC Grant Immunobile, contract 694717), European Commission, INSERM, Université Lille 2 (Appel à projets «orientations stratégiques»: convention $n^{\circ}$ A007) and SATT Nord (M0075/SATTNORD). Manuel Lasalle and 
Vanessa Hoguet are recipients of a doctoral fellowship of the French Ministère de la Recherche. NMR acquisitions were done at the Laboratoire d'Application de Résonance Magnétique Nucléaire (LARMN), Lille, France. Bart Staels is a member of the Institut Universitaire de France.

\section{ABBREVIATIONS}

EtOAc, ethyl acetate; $\mathrm{CH}_{3} \mathrm{CN}$, acetonitrile; DCE, 1,2-dichloroethane; DCM, dichloromethane; DIEA, diisopropylethylamine; DIO, diet-induced obese; DME, dimethoxyethane; DMF, N,Ndimethylformamide; DMSO, dimethyl sulfoxide; EtOH, ethanol; eq, equivalent; GI, gastrointestinal; GLP-1, Glucagon Like Peptide-1; GP-BAR1, G-protein coupled bile acid receptor 1; HFD, High Fat Diet; MeOH, methanol; PBS, phosphate buffered saline; SAR, structure-activity relationships; TEA, triethylamine; TCDI, 1,1'-Thiocarbonyldiimidazole; TGR5, Takeda Gprotein-coupled receptor 5; THF, tetrahydrofuran; TLC, thin layer chromatography. T3P, 1Propylphosphonic acid cyclic anhydride.

\section{REFERENCES}

(1) Lefebvre, P.; Cariou, B.; Lien, F.; Kuipers, F.; Staels, B. Role of bile acids and bile acid receptors in metabolic regulation. Physiol. Rev. 2009, 89, 147-191.

(2) Wang, H.; Chen, J.; Hollister, K.; Sowers, L. C.; Forman, B. M. Endogenous bile acids are ligands for the nuclear receptor FXR/BAR. Mol. Cell 1999, 3, 543-553. 
(3) Maruyama, T.; Miyamoto, Y.; Nakamura, T.; Tamai, Y.; Okada, H.; Sugiyama, E.; Nakamura, T.; Itadani, H.; Tanaka, K. Identification of membrane-type receptor for bile acids (M-BAR). Biochem. Biophys. Res. Commun. 2002, 298, 714-719.

(4) Kawamata, Y.; Fujii, R.; Hosoya, M.; Harada, M.; Yoshida, H.; Miwa, M.; Fukusumi, S.; Habata, Y.; Itoh, T.; Shintani, Y.; Hinuma, S.; Fujisawa, Y.; Fujino, M. A G protein-coupled receptor responsive to bile acids. J. Biol. Chem. 2003, 278, 9435-9440.

(5) Porez, G.; Prawitt, J.; Gross, B.; Staels, B. Bile acid receptors as targets for the treatment of dyslipidemia and cardiovascular disease. J. Lipid. Res. 2012, 53, 1723-1737.

(6) Campbell, J. E.; Drucker, D. J. Pharmacology, physiology, and mechanisms of incretin hormone action. Cell Metab. 2013, 17, 819-837.

(7) Watanabe, M.; Houten, S. M.; Mataki, C.; Christoffolete, M. A.; Kim, B. W.; Sato, H.; Messaddeq, N.; Harney, J. W.; Ezaki, O.; Kodama, T.; Schoonjans, K.; Bianco, A. C.; Auwerx, J. Bile acids induce energy expenditure by promoting intracellular thyroid hormone activation. Nature 2006, 439, 484-489.

(8) Broeders, E. P.; Nascimento, E. B.; Havekes, B.; Brans, B.; Roumans, K. H.; Tailleux, A.; Schaart, G.; Kouach, M.; Charton, J.; Deprez, B.; Bouvy, N. D.; Mottaghy, F.; Staels, B.; van Marken Lichtenbelt, W. D.; Schrauwen, P. The bile acid chenodeoxycholic acid increases human brown adipose tissue activity. Cell Metab. 2015, 22, 418-426.

(9) Lavoie, B.; Balemba, O. B.; Godfrey, C.; Watson, C. A.; Vassileva, G.; Corvera, C. U.; Nelson, M. T.; Mawe, G. M. Hydrophobic bile salts inhibit gallbladder smooth muscle function 
via stimulation of GPBAR1 receptors and activation of KATP channels. J. Physiol. 2010, 588, 3295-3305.

(10) Keitel, V.; Cupisti, K.; Ullmer, C.; Knoefel, W. T.; Kubitz, R.; Häussinger, D. The membrane-bound bile acid receptor TGR5 is localized in the epithelium of human gallbladders. Hepatology 2009, 50, 861-870.

(11) Alemi, F.; Kwon, E.; Poole, D. P.; Lieu, T.; Lyo, V.; Cattaruzza, F.; Cevikbas, F.; Steinhoff, M.; Nassini, R.; Materazzi, S.; Guerrero-Alba, R.; Valdez-Morales, E.; Cottrell, G. S.; Schoonjans, K.; Geppetti, P.; Vanner, S. J.; Bunnett, N. W.; Corvera, C. U. The TGR5 receptor mediates bile acid-induced itch and analgesia. J. Clin. Invest. 2013, 123, 1513-1530.

(12) Futatsugi, K.; Bahnck, K. B.; Brenner, M. B.; Buxton, J.; Chin, J. E.; Coffey, S. B.; Dubins, J.; Flynn, D.; Gautreau, D.; Guzman-Perez, A.; Hadcock, J. R.; Hepworth, D.; Herr, M.; Hinchey, T.; Janssen, A. M.; Jennings, S. M.; Jiao, W.; Lavergne, S. Y.; Li, B.; Li, M.; Munchhof, M. J.; Orr, S. T. M.; Piotrowski, D. W.; Roush, N. S.; Sammons, M.; Stevens, B. D.; Storer, G.; Wang, J.; Warmus, J. S.; Wei, L.; Wolford, A. C. Optimization of triazole-based TGR5 agonists towards orally available agents. Med. Chem. Comm. 2013, 4, 205-210.

(13) Piotrowski, D. W.; Futatsugi, K.; Warmus, J. S.; Orr, S. T.; Freeman-Cook, K. D.; Londregan, A. T.; Wei, L.; Jennings, S. M.; Herr, M.; Coffey, S. B.; Jiao, W.; Storer, G.; Hepworth, D.; Wang, J.; Lavergne, S. Y.; Chin, J. E.; Hadcock, J. R.; Brenner, M. B.; Wolford, A. C.; Janssen, A. M.; Roush, N. S.; Buxton, J.; Hinchey, T.; Kalgutkar, A. S.; Sharma, R.; Flynn, D. A. Identification of tetrahydropyrido[4,3-d]pyrimidine amides as a new class of orally bioavailable TGR5 agonists. ACS Med. Chem. Lett. 2013, 4, 63-68. 
(14) Fryer, R. M.; Ng, K. J.; Nodop Mazurek, S. G.; Patnaude, L.; Skow, D. J.; Muthukumarana, A.; Gilpin, K. E.; Dinallo, R. M.; Kuzmich, D.; Lord, J.; Sanyal, S.; Yu, H.; Harcken, C.; Cerny, M. A.; Cerny, M. C.; Hickey, E. R.; Modis, L. K. G protein-coupled bile acid receptor 1 stimulation mediates arterial vasodilation through a $\mathrm{K}_{\mathrm{Ca}} 1.1\left(\mathrm{BK}_{\mathrm{Ca}}\right)$-dependent mechanism. $J$. Pharmacol. Exp. Ther. 2014, 348, 421-431.

(15) Charmot, D. Non-systemic drugs: a critical review. Curr. Pharm. Des. 2012, 18, 1434-1445.

(16) Duan, H.; Ning, M.; Zou, Q.; Ye, Y.; Feng, Y.; Zhang, L.; Leng, Y.; Shen, J. Discovery of intestinal targeted TGR5 agonists for the treatment of type 2 diabetes. J. Med. Chem. 2015, 58, 3315-3328.

(17) Cao, H.; Chen, Z.-X.; Wang, K.; Ning, M.-M.; Zou, Q.-A.; Feng, Y.; Ye, Y.-L.; Leng, Y.; Shen, J.-H. Intestinally-targeted TGR5 agonists equipped with quaternary ammonium have an improved hypoglycemic effect and reduced gallbladder filling effect. Sci. Rep. 2016, 6, 28676.

(18) Kramer, W.; Glombik, H. Bile acid reabsorption inhibitors (BARI): novel hypolipidemic drugs. Curr. Med. Chem. 2006, 13, 997-1016.

(19) Bollu, V.; Boren, B. C.; Dalgard, J. E.; Flatt, B. T.; HAQ, N.; Hudson, S.; Mohan, R.; Morrissey, M.; Pratt, B.; Wang T.-L. Triazole and imidazole derivatives for use as TGR5 agonists in the treatment of diabetes and obesity. WO2010/093845, 2010.

(20) Zamansky, I.; Galvin, G.; Girardet, J.-L. Polymorphic, crystalline and mesophase forms of sodium 2-(5-bromo-4-(4-cyclopropylnaphthalen-1-yl)-4H-1,2,4-triazol-3-ylthio)acetate, and uses thereof. WO/2011/085009, 2011. 
(21) Lasalle, M.; Picon, S.; Rajaa, B.; Hoguet, V.; Van Obbergen, J.; Roussel, P.; Deprez, B.; Charton, J. Access to newly functionalized imidazole derivatives: efficient synthesis of novel 5amino-2-thioimidazoles using propylphosphonic anhydride (®T3P). Tetrahedron Lett. 2015, 56, 1011-1014.

(22) Fournie-Zaluski, M.-C.; Llorens-Cortes, C.; Roques, B. P.; Corvol, P. Novel derivatives of 4,4'-dithiobis-(3-aminobutane-1-sulfphonates) and compositions containing same. US 2006/0135602, 2006.

(23) Egan, W. J.; Merz, K. M.; Baldwin, J. J. Prediction of drug absorption using multivariate statistics. J. Med. Chem. 2000, 43, 3867-3877.

(24) Veber, D. F.; Johnson, S. R.; Cheng, H. Y.; Smith, B. R.; Ward, K. W.; Kopple, K. D. Molecular properties that influence the oral bioavailability of drug candidates. J. Med. Chem. 2002, $45,2615-2623$.

(25) Katrin, P.; Patric, S.; Kristina, L.; Per, A. Polar molecular surface properties predict the intestinal absorption of drugs in humans. Pharm. Res. 1997, 14, 568-571.

(26) Li, T.; Holmstrom, S. R.; Kir, S.; Umetani, M.; Schmidt, D. R.; Kliewer, S. A.; Mangelsdorf, D. J. The G protein-coupled bile acid receptor, TGR5, stimulates gallbladder filling. Mol.Endocrinol. 2011, 25, 1066-1071.

(27) Briere, D.A.; Ruan, X.; Cheng, C.C.; Siesky, A.M.; Fitch, T.E.; Dominguez, C.; Gutierrez Sanfeliciano, S.; Montero, C.; Suen, C.S.; Xu, Y.; Coskun, T.; Michael, M.D. Novel small molecule agonist of TGR5 possesses anti-diabetic effects but causes gallbladder filling in mice. PLOS ONE 2015, 10, e0136873. 
(28) Brighton, C. A.; Rievaj, J.; Kuhre, R. E.; Glass, L. L.; Schoonjans, K.; Holst, J. J.; Gribble, F. M.; Reimann, F. Bile acids trigger GLP-1 release predominantly by accessing basolaterally located G protein-coupled bile acid receptors. Endocrinology 2015, 156, 3961-3970

(29) Charton, J.; Deprez, B.; Leroux, F., Staels, B.; Muhr-Tailleux A.; Hennuyer, N.; Lestavel, S.; Lasalle M.; Dubanchet, B. Imidazol- or 1,2,4-triazol-derivatives and their use. WO2015/189330 A1, 2015

(30) Sevin, E.; Dehouck, L.; Fabulas-da Costa, A.; Cecchelli, R.; Dehouck, M. P.; Lundquist, S.; Culot, M. Accelerated Caco-2 cell permeability model for drug discovery. J. Pharmacol. Toxicol. Methods 2013, 68, 334-339. 
Table of Content Graphic

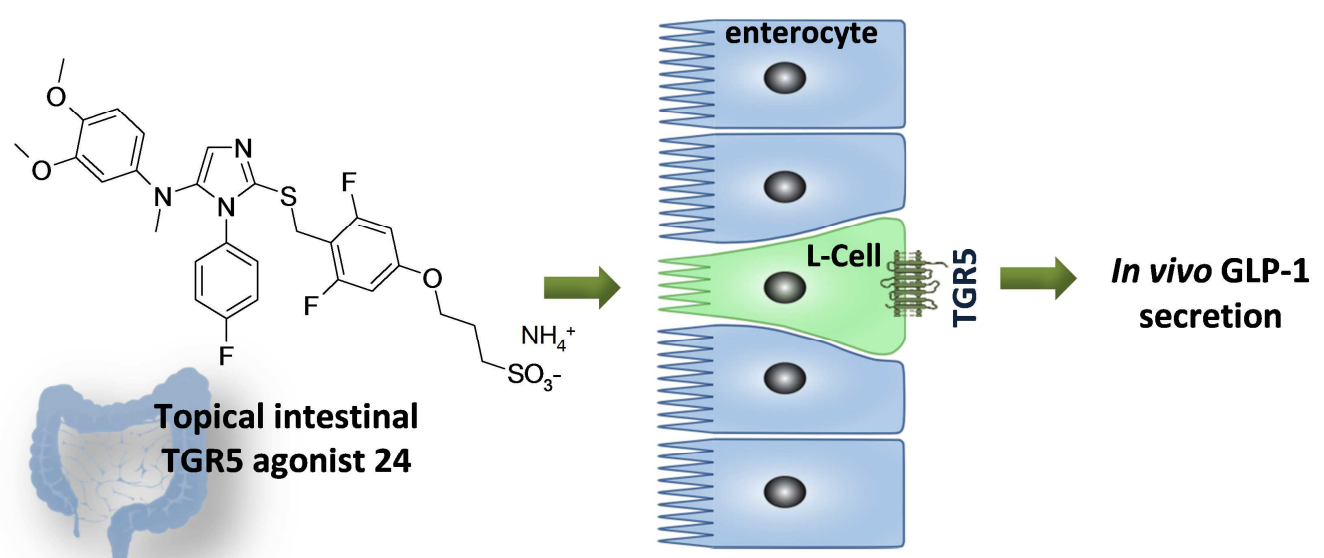

